\title{
A DISPUTA PELO DIREITO À CIDADE NO CAMPO JURÍDICO UMA ANÁLISE A PARTIR DE CASOS DA DEFENSORIA PÚBLICA DO ESTADO DE SÃO PAULO
}

\begin{abstract}
Dissertação apresentada ao Programa de Pós-Graduação da Faculdade de Arquitetura e Urbanismo da Universidade de São Paulo para a obtenção do título de mestre em Arquitetura e Urbanismo.
\end{abstract}

Área de Concentração: Habitat

Orientadora: Prof ${ }^{\mathrm{a}} \mathrm{Dr}^{\mathrm{a}}$ Maria Lúcia Refinetti Rodrigues Martins

São Paulo 
Autorizo a reprodução e divulgação total ou parcial deste trabalho, por qualquer meio convencional ou eletrônico, para fins de estudo e pesquisa, desde que citada a fonte.

Lima, Rafael Negreiros Dantas de

A disputa pelo direito à cidade no campo jurídico: uma análise a partir de casos da Defensoria pública do Estado de são Paulo / Rafael Negreiros Dantas de Lima; orientadora Maria Lúcia Refinetti Rodrigues Martins. - são Paulo, 2018. 113

Dissertação (Mestrado) - Faculdade de Arquitetura e Urbanismo da Universidade de são Paulo. Área de concentração: Habitat

1. Direito Urbanístico. 2. Direito À Moradia. 3 Defensor público. 4. Tópica Jurídica. I. Martins, Maria Lúcia Refinetti Rodrigues, orient. II. Título.

Elaborada eletronicamente através do formulário disponível em: $<$ http://www.fau.usp.br/fichacatalografica/> 


\section{DEDICATÓRIA}

Para Amanda, por tudo até aqui e para Letícia por tudo que há de vir. 


\section{AGRADECIMENTOS}

À Faculdade de Arquitetura e Urbanismo por ter me acolhido ao longo destes mais de 02 anos em suas dependências, oferecendo toda sua estrutura para o desenvolvimento desta dissertação de mestrado.

Aos professores que ministraram aulas e demais profissionais desta instituição.

Um agradecimento especial a minha orientadora, Maria Lúcia Refinetti Martins, por toda a contribuição, paciência, simplicidade e receptividade. Em especial, um agradecimento pelos últimos meses, em que colaborou de forma decisiva para o esclarecimento das ideias, objetivos e métodos, permitindo que esta dissertação chegasse ao resultado pretendido.

À Defensoria Pública do Estado de São Paulo por ter permitido o desenvolvimento acadêmico de um membro de seus quadros, especialmente aos colegas da Unidade de Itaquera que contribuíram nesta jornada.

A todos os familiares e amigos que colaboraram de alguma forma, desde simples diálogos a ideias relevantes.

À minha esposa por toda a convivência, compreensão, ajuda, carinho e amor. 


\section{RESUMO}

O período pós Constituição Federal de 1988 foi marcado por intensas conquistas normativas sobre as cidades, com legislações avançadas, porém, que não resultaram em uma mudança significativa de concepção de políticas públicas ou na jurisprudência dos Tribunais. A pressuposição do Direito como um sistema autônomo, neutro e universal, que traz soluções para todos os casos concretos, por meio do método dogmático, não permite que se chegue a justificativas satisfatórias para esta inefetividade. A presente dissertação pretende apresentar uma análise sobre como se desenvolve a disputa pelo direito à cidade no campo jurídico, explicitando as abordagens com que este tema é tratado na prática jurídica. Por meio da observação de casos concretos em que há o confronto entre instituições e profissionais jurídicos, busca-se demonstrar como estes concorrem pelo monopólio de impor sua visão de mundo, mascarando as relações de poder pelo discurso jurídico. Além disso, utilizase da tópica jurídica para avaliar, em cada caso, como o pensamento dos juristas se desenvolve diante dos problemas aparentemente insolucionáveis. Tomando por base tal metodologia, visa-se a uma apresentação do jogo de poder em torno do direito à cidade que ocorre no campo jurídico, avaliando-se quais as possibilidades da concepção do direito à cidade numa lógica de justiça social, ser consolidada e aplicada efetivamente, conferindo à parcela mais frágil da população o acesso aos bens e serviços da cidade.

Palavras-chave: 1. Direito Urbanístico. 2. Direito à Moradia 3. Defensor Público. 4. Tópica Jurídica. I. Martins, Maria Lúcia Refinetti Rodrigues, orient. II. Título. 


\begin{abstract}
The period after the Federal Constitution of 1988 was marked by intense normative achievements over the cities, with advanced legislation, however, which did not result in a significant change in the conception of public policies or in the jurisprudence of the Courts. The presupposition of Law as an autonomous, neutral and universal system, which brings solutions to all concrete cases, through the dogmatic method, does not allow us to arrive at satisfactory justifications for this ineffectiveness. The present dissertation intends to present an analysis on how the dispute for the right to the city in the juridical field develops, explaining the approaches with which this subject is treated in the legal practice. Through the observation of concrete cases in which there is a confrontation between legal institutions and professionals, it is sought to demonstrate how they compete for the monopoly of imposing their world view, masking the relations of power by the legal discourse. In addition, it uses the legal topics to assess, in each case, how the thinking of lawyers develops in the face of seemingly unsolvable problems. Based on this methodology, it is aimed at a presentation of the power game around the right to the city that occurs in the legal field, evaluating the possibilities of the conception of the right to the city in a logic of social justice, being consolidated and applied effectively, giving the most fragile part of the population access to the goods and services of the city.
\end{abstract}

Key-words: 1. Urban Law. 2. Right to Housing 3. Public Defender. 4. Legal Topics. I. Martins, Maria Lúcia Refinetti Rodrigues, orient. II. Title. 


\section{LISTA E ABREVIATURA DE SIGLAS}

ANOREG

$\mathrm{ACP}$

APP

$\mathrm{BNH}$

CDHU

CF

$\mathrm{CFMH}$

CPP

CSDP

CUEM

DER

GARMIC

GAEMA

IG

LC

MP

NHABURB

ONG

OUCAE

PA

PDT

PMCMV

PT

PTB

SEP

SINDIPROESP

TJSP

UMM

USP

ZEIS
Associação de Notários e Registradores

Ação Civil Pública

Área de Preservação Permanente

Banco Nacional de Habitação

Companhia de Desenvolvimento Habitacional e Urbano

Constituição Federal

Conselho do Fundo Municipal de Habitação

Companhia Paulista de Parcerias

Conselho Superior da Defensoria Pública

Concessão de Uso Especial para Fins de Moradia

Departamento de Estradas de Rodagem

Grupo de Articulação para Moradia do Idoso na Capital

Grupo de Atuação Especial de Defesa do Meio Ambiente Instituto Geológico

Lei Complementar

Medida Provisória

Núcleo de Habitação e Urbanismo

Organização Não Governamental

Operação Urbana Consorciada Água Espraiada

Procedimento Administrativo

Partido Democrático Trabalhista

Programa Minha Casa Minha Vida

Partido dos Trabalhadores

Partido Trabalhista Brasileiro

Secretaria de Planejamento

Sindicato dos Procuradores do Estado de São Paulo

Tribunal de Justiça de São Paulo

União dos Movimentos de Moradia

Universidade de São Paulo

Zona Especial de Interesse Social 


\section{SUMÁRIO}

INTRODUÇÃO

CAPÍTULO 01 - A DEFENSORIA PÚBLICA E O DIREITO À CIDADE COMO ACESSO AOS BENS E SERVIÇOS DA CIDADE

1.1. O CONCEITO DE ACESSO À JUSTIÇA COMO FUNDADOR DA DEFENSORIA PÚBLICA.

1.2. A DEFENSORIA PÚBLICA A PARTIR DA CONSTITUIÇÃO DE 1988........ 12

1.3. A CRIAÇÃO DA DEFENSORIA PÚBLICA DE SÃO PAULO A PARTIR DA ARTICULAÇÃO COM CENTENAS DE ENTIDADES DA SOCIEDADE CIVIL

1.3.1. A previsão de um Núcleo Especializado em Habitação e Urbanismo para a Defensoria Pública do Estado de São Paulo 16

Capítulo 02 - O DIREITO COMO CAMPO JURíDICO E O USO DA TÓPICA NA DISPUTA PELO DIREITO À CIDADE.

2.1. DA LIMITAÇÃO QUE O DOGMATISMO JURÍDICO TRAZ PARA ANÁLISES SOBRE O DIREITO À CIDADE.

2.2. O DIREITO COMO CAMPO JURÍDICO

2.3. A TÓPICA JURÍDICA EM THEODOR VIEHWEG 28

2.3.1. Da força do direito à cidade como um topos. 32

CAPITULO 04 - A DISPUTA PELO MONOPÓLIO DO DIREITO À CIDADE: UMA LEITURA A PARTIR DE CASOS CONCRETOS ENVOLVENDO A DEFENSORIA PÚBLICA DO ESTADO DE SÃO PAULO

4.1. CASO 01: REMOÇÕES DE FAMÍLIAS NO PROGRAMA DE DEFESA DOS MANANCIAIS DE ÁGUA DA PREFEITURA MUNICIPAL DE SÃO PAULO.

4.1.1. A Judicialização do conflito entre Prefeitura Municipal e Moradores e o uso dos topoi 39

4.1.2. As relações de poder no campo jurídico reveladas nas Ações Civis Públicas

4.2. CASO 02: LEILÕES DE IMÓVEIS NA REGIÃO DAS ÁGUAS ESPRAIADAS PELO GOVERNO DO ESTADO DE SÃO PAULO 
4.2.1. A formação dos topoi para a disputa judicial inicial.

4.2.2. Influências políticas sobre o Poder Judiciário e o topos do

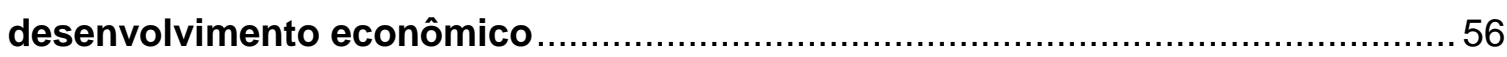

4.2.3. A atuação da Defensoria Pública e seus efeitos ............................... 58

4.2.4. Da ausência de uma visão urbanística e da disputa em torno do topos do "interesse público"

4.3. CASO 03: O DIREITO À MORADIA EM FACE DA DEFESA DO MEIO AMBIENTE PELO MINISTÉRIO PÚBLICO ESTADUAL EM POÁ-SP

4.3.1. A inserção do Ministério Público no campo jurídico pela questão ambiental

4.3.2. A linguagem dos moradores e a cisão profanos/profissionais. 69

4.3.3. As diferenças entre o discurso jurídico e a imposição da realidade 70

4.3.4. A atuação da Defensoria Pública 72

4.3.5. O resultado das Ações Civis Públicas no Poder Judiciário 74

4.4. CASO 04: A LUTA PELA LOCAÇÃO SOCIAL 77

4.4.1. A propositura de Mandado de Injunção 80

4.4.2. Efeitos Políticos do caso 83 CONCLUSÃO 85

BIBLIOGRAFIA 99 


\section{INTRODUÇÃO}

A presente dissertação de mestrado é uma pesquisa jurídica desenvolvida em um programa de Arquitetura e Urbanismo, o que implica o desafio de articular duas diferentes bases disciplinares com conceitos, linguagens e metodologias próprias. Consiste no esforço de iluminar o significado, bem como as disputas em torno do "direito à cidade" na prática jurídica, buscando explicitações e explicações sobre suas limitações. Para tanto, são observados casos concretos de procedimentos instaurados pelo Núcleo de Habitação da Defensoria Pública do Estado de São Paulo, cuja missão é atuar em demandas coletivas ou individuais de caráter geral, referentes direta ou indiretamente, ao direito à moradia e ao direito à cidade' .

O fato de a Defensoria Pública do Estado de São Paulo possuir como missão institucional a defesa da população pobre ${ }^{2}$, traz uma tendência de que sua operacionalização do conteúdo do direito à cidade seja feita sob a visão do marginalizado no processo de formação do espaço urbano. Além disso, a configuração desta instituição no cenário paulista teve a particularidade de ser fruto de uma reivindicação e mobilização de centenas de movimentos sociais, muitos destes atores oriundos da luta por moradia e por cidades democráticas.

Este fator não se limita a uma referência histórica, mas foi elemento determinante para a existência dentro da Defensoria Pública de um setor especificamente vinculado à temática da habitação e do urbanismo, moldando sua forma de atuação institucional. Assim, entende-se, a priori, que esta instituição pública se apresenta como um potencial articulador jurídico de um direito à cidade relacionado com a justiça social e cada vez mais desenvolvido no âmbito normativo.

Sabe-se que a luta pela reforma urbana permitiu a previsão de uma política urbana na Constituição Federal que tem por objetivo o pleno desenvolvimento das funções sociais da cidade e a garantia do bem-estar de seus habitantes. Posteriormente, surge o Estatuto da Cidade (Lei oㅜ 10.257/2001) - que se propõe a regular o uso da propriedade urbana em prol do bem coletivo, da segurança e do bem-

\footnotetext{
${ }^{1}$ Art. $3^{\circ}$ da Deliberação do Conselho Superior da Defensoria Pública ํㅡ 105/2008.

$2 \mathrm{O}$ artigo 134 da Constituição Federal define como público-alvo da Defensoria Pública como "necessitados", porém nesta dissertação se utilizarão as nomenclaturas "pobre" ou "vulnerável", pois a primeira tem uma acepção de viés econômico e a segunda socioeconômico que seriam mais adequados que a terminologia constitucional, que não apresenta um significado distintivo.
} 
estar dos cidadãos - e diversas outras normas relevantes como a Medida Provisória 2.220/01, Planos Diretores, assim como leis tratando de temas como regularização fundiária, saneamento básico, mobilidade urbana. Em que pesem conquistas em termos de marcos normativos sobre aspectos das cidades, não se percebe uma mudança significativa de concepção nas definições de políticas públicas ou em decisões judiciais ${ }^{3}$, trazendo uma situação de perplexidade ante os poucos resultados práticos para uma luta por cidades mais justas. As explicações que se tenta oferecer no âmbito do Direito para esta inefetividade do direito à cidade, normalmente trazem conclusões que redundam em rótulos e generalizações que pouco esclarecem este fenômeno.

Há diversos estudos que se propõem a analisar a resposta dos Tribunais de Justiça à nova legislação urbanística, normalmente, por meio da consulta a banco de dados jurisprudencial, perquirindo a quantidade de julgamentos que acolhem ou não direitos como o de moradia ou que tragam referências ao Estatuto da Cidade. Ao constatarem o baixo volume de decisões utilizando tais conceitos ou acolhendo os objetivos trazidos no referido arcabouço legal, tais pesquisas tendem a creditar o fato ao desconhecimento da legislação pelos juízes e desembargadores ou ao conservadorismo do Poder Judiciário.

Outra dificuldade de avaliação ocorre pela pressuposição do fenômeno jurídico como sendo explicado apenas pelo positivismo dogmático. Esta concepção entende que o Direito se restringe a um ordenamento definido pelo Estado, que é formado por um sistema de normas escalonadas hierarquicamente, que fornecem conceitos, princípios e regras pelas quais se chegaria a uma interpretação clara para os conflitos existentes. Se os dogmas conduzem a atividade do julgador e se existe uma regulamentação sobre as cidades no país que define padrões de uso da propriedade que se submetem ao bem coletivo - por meio de diretrizes que preveem a gestão democrática das cidades - não se consegue explicar juridicamente o motivo de grande parte da jurisprudência não acolher os dogmas urbanísticos.

Cumpre destacar que as conclusões dos estudos que se costumam realizar, tendo por objeto a baixa repercussão do aparato normativo do direito à cidade sobre as decisões judiciais, tendem a redundar em avaliações de ordem política - atribuindo tal fato a eventuais influências sobre o Poder Judiciário - ou em afirmações de que a

3 O termo "decisão judicial" é colocado em sentido amplo, englobando decisões interlocutórias, sentenças ou acórdãos. 
norma não teria eficácia por ser frágil ou, novamente, pelo conservadorismo do Poder Judiciário. Ainda que essas modalidades de pesquisas avancem em dar visibilidade ao tema, têm grandes limitações, já que não conseguem retratar com maior profundidade e fidedignidade como funciona o processo de disputa pelos direitos no meio jurídico.

Para alcançar tal objetivo, se tomará como pressuposto a concepção de Pierre Bourdieu (2012, p. 212) de Direito como campo jurídico, ou seja, o espaço em que há a concorrência entre os agentes e instituições para o exercício da competência social e técnica de interpretar um corpus de textos que consagra a visão legítima, justa do mundo social. A referência a Bourdieu é relevante para trazer as relações de poder da sociedade para dentro do Direito, deixando de lado avaliações que o consideram como uma estrutura social completamente autônoma e neutra.

Neste sentido, o Direito não seria um sistema fechado, com normas de conteúdo definido aguardando aplicação. Coloca-se o Direito como um campo em que instituições e profissionais travam uma disputa pela imposição de suas visões de mundo, utilizando-se de uma linguagem especializada - a jurídica - que oculta este verdadeiro jogo de poder. O foco se dará em como se desenvolve a disputa entre os diversos atores jurídicos na construção do direito à cidade, o que resulta em uma conformação que confere novo formato a este direito.

Perceba-se que, para esta pretensão, entende-se a criação do Direito não apenas na esfera normativa ou interpretativa, mas também no âmbito decisional, ou seja, há casos em que há conflitos inconciliáveis, em que não há solução no ordenamento jurídico, de modo que a atividade julgadora se torna criativa. Entretanto, esta elaboração não é feita apenas pelo julgador, mas por todos os operadores jurídicos que concorrem discursivamente pela aplicação de sua concepção sobre um direito em questão. Além disso, se compreenderá o Direito não apenas como algo trabalhado nos processos judiciais, mas em todo e qualquer ato administrativo ou procedimento em que haja a aplicação ou a interpretação jurídica.

Nesta perspectiva de análise do desenvolvimento do direito à cidade na prática jurídica, torna-se essencial o estudo de casos concretos. Como referido, o ponto de partida será o Núcleo de Habitação da Defensoria Pública do Estado de São Paulo como articulador de um direito à cidade interpretado sob os interesses da população pobre, que será colocado em confronto com diversas outras acepções do aludido 
direito, o que, na maior parte das ocasiões, resulta em um processo judicial, contendo decisões proferidas pelo Poder Judiciário.

O fato de os casos concretos envolverem a jurisprudência, exige uma teorização para detalhar como se desenvolve o raciocínio dos juristas diante da necessidade de resolver conflitos, o que será possível utilizando-se dos ensinamentos sobre tópica por Theodor Viehweg. O referido jusfilósofo explica que, diante de casos sem solução - a exemplo do conflito de um direito fundamental como a propriedade, ante outro de mesma magnitude como moradia - um jurista não pensa de forma sistemática, mas faz uso de um pensamento problemático.

Seja um julgador ou qualquer outro operador jurídico, ao ter um conflito jurídico diante de si, o jurista não parte da análise de um sistema de normas, em que busca os dogmas estabelecidos, não fazendo uma atividade dedutiva, passando por normas inferiores, até chegar a uma solução para o caso concreto. Isso porque, nestas questões insolúveis (aporias), o sistema não traria resposta ao caso concreto, por ser rígido, enquanto a realidade social é dinâmica, o que exige outra atividade do intérprete: o pensamento por problemas. Assim, o jurista analisa o problema e parte para a busca de lugares comuns (topoi) dispostos em qualquer sistema, gerando pontos de partida para que se desenvolva uma solução entre as partes para o caso.

Em síntese, a busca destes dois referenciais teóricos para avaliar como o direito à cidade se desenvolve a partir da prática dos operadores jurídicos, serão importantes, primeiro, porque a concepção de campo jurídico explicará bem as relações de poder entre os agentes que constroem o Direito, disputando um monopólio pelo poder de dizer o direito à cidade. Depois, a tópica jurídica permitirá analisar como se desenvolveu o pensamento problemático de cada agente, que topoi cada um buscou, a origem ideológica da fundamentação e como se chegou a uma decisão. Operadores articulam seus raciocínios, quais os fundamentos de seus discursos e como se chega a uma decisão judicial.

$\mathrm{Na}$ escolha dos casos para análise, foi realizada uma triagem tendo como base uma planilha com todos os casos em que o Núcleo de Habitação e Urbanismo da Defensoria Pública do Estado de São Paulo atuou desde o ano de 2006 até 2017. Houve uma entrevista prévia com coordenadores e ex-coordenadores do Núcleo de Habitação e Urbanismo e a leitura de todos os seus relatórios semestrais (de 2012 a 2017) para identificar casos de grande repercussão, o que seria representado 
principalmente pela quantidade de pessoas atingidas e pela possibilidade de impacto social e político, a depender da decisão jurídica a ser proferida.

Diante desta avaliação preliminar, que reduziu o montante de casos, os critérios utilizados foram os seguintes:

a) Diversidade de instituições ou profissionais atuantes no campo jurídico, porém portadores de grande poder simbólico, possibilitando demonstrar a disputa do direito à cidade em um campo formado por inúmeros atores articuladores de visões do direito à cidade que estabelecem sua compreensão de forma consolidada. Escolheram-se casos contendo o Governo do Estado de São Paulo, a Prefeitura do Município de São Paulo, o Ministério Público do Estado de São Paulo e o Poder Judiciário do Estado de São Paulo, todos em conflito com a Defensoria Pública do Estado de São Paulo.

b) Variedade dos discursos articulados sobre a cidade entre os casos, que permitisse mostrar quais os topoi trabalhados para cada tipo de noção de cidade, qual a percepção de cidade por trás de cada topos, analisando-se os motivos da aceitação ou não de cada tipo de argumento.

c) Não fez parte da busca o êxito na atuação pela Defensoria Pública, assim como foi importante que em nenhum caso este pesquisador estivesse envolvido ${ }^{4}$, mantendo a imparcialidade de avaliação.

Assim, foram triados três casos, tendo sido constatado, contudo, que, em todos estes, havia possibilidade de remoção de famílias, o que conduz a atuação da Defensoria Pública para um viés de ator reativo, visando a evitar um dano iminente. Assim, buscou-se um último caso em que houvesse uma atuação ativa daquela Instituição, ou seja, em que o Núcleo de Habitação e Urbanismo tenha exercido uma função de fiscalização do cumprimento da legislação urbanística, na busca da promoção de direitos.

Ante os casos selecionados, utilizou-se como fonte os procedimentos administrativos (PA's) que foram instaurados no Núcleo de Habitação e Urbanismo para cada um dos casos, anotando-se cada ato administrativo, envio de ofícios e

\footnotetext{
${ }^{4}$ Este mestrando exerce a função de Defensor Público do Estado de São Paulo desde o ano de 2013.
} 
respostas recebidas, assim como as principais peças processuais. Os procedimentos administrativos permitiram um encadeamento cronológico dos casos, entendendo como a Defensoria Pública foi chamada à questão, como foram formados seus argumentos e como ocorreu a disputa fora do Poder Judiciário.

Além dos procedimentos, foram tomados como fonte os processos judiciais, que possibilitavam a busca do discurso dos demais agentes jurídicos, assim como as decisões judiciais, além das notícias da imprensa na época, para que houvesse uma melhor percepção sobre a repercussão política e social dos casos.

Diante dos pressupostos, da metodologia e das fontes estabelecidas, a pesquisa será apresentada em quatro capítulos.

O primeiro capítulo "A Defensoria Pública e o direito à cidade como acesso a bens e serviços da cidade" visa a compreender como o Núcleo de Habitação e Urbanismo da Defensoria Pública de São Paulo se propõe a defender o direito à cidade. Realiza-se, portanto, um resgate dos conceitos formuladores do acesso à justiça, da noção de Defensoria Pública a partir da Constituição Federal de 1988, assim como o processo de criação do referido órgão no estado de São Paulo, o que revela com maior detalhe a sua missão institucional, os compromissos por ele estabelecidos e as suas relações com agentes de luta por cidades democráticas, que moldam sua forma de atuação.

Neste estudo, tenta-se estabelecer como a Instituição assume seus pressupostos do direito à cidade, de forma abstrata, na montagem de seu aparato burocrático, o que será importante para contrastar com o formato que este direito adquirirá na prática institucional, a partir das necessidades do cotidiano, o que será objeto de análise no terceiro capítulo.

O Segundo capítulo intitulado "O Direito como campo jurídico e o uso da tópica na disputa pelo direito à cidade" desenvolve o paradigma do Direito como um espaço de disputa pelo monopólio de definição do conteúdo dos direitos, consolidando as visões de mundo de forças sociais dominantes. Revela-se como o paradigma de um Direito tido como autônomo de influências de outras estruturas sociais - como a política e a economia - neutro e aplicável universalmente, são parte de uma linguagem simbólica que oculta as relações de poder que mantém a ordem. Com tal noção, viabiliza-se uma análise de casos concretos em que se perceba qual a ordem urbanística que cada agente tenta impor. 
Somando-se a esta concepção, desenvolve-se a teoria da tópica jurídica feita por Theodor Viehweg, demonstrando o pensamento dos juristas a partir dos problemas - e não pelo sistema - o que confere instrumentos para observação nos casos concretos de quais os fundamentos que cada instituição ou profissional utiliza para defender sua visão sobre o direito à cidade. Demonstra-se que quando se fala em "direito à cidade" ou no "interesse público" cada jurista parte de um ponto de partida pré-concebido, que condiciona toda sua atuação.

No terceiro capítulo, "A disputa pelo monopólio do direito à cidade: uma leitura a partir de casos concretos envolvendo o Núcleo de Habitação da Defensoria Pública do Estado de São Paulo", atinge-se o cerne desta dissertação, com o estudo dos quatro casos concretos escolhidos. O caso 01 traz a atuação da Defensoria Pública diante do risco de remoção de milhares de famílias a partir de um plano de recuperação ambiental de áreas de mananciais desenvolvido pela Prefeitura Municipal de São Paulo. O referido plano era regulamentado pela chamada Ordem Interna no 01/2007 - um ato normativo da Prefeitura - que permitia a remoção de moradores em área de mananciais, sem proposição de ação judicial ou garantia de qualquer direito assistencial ou habitacional. $O$ caso é relevante para demonstrar como a disputa pelo direito à cidade não ocorre apenas no âmbito jurisprudencial e que em cada ato interpretativo dos operadores jurídicos há a construção de uma linguagem simbólica sobre o referido direito, que o consolida no campo jurídico.

O caso 02 apresenta um plano de venda de imóveis pelo Governo do Estado de São Paulo que colocou em risco a moradia de centenas de moradores, exigindo uma intervenção da Defensoria Pública. Assim como no caso anterior, há um grande contraste entre as noções de cidade trazidas pelo Governo e pela Defensoria, sendo bastante esclarecedor perceber a posição do Poder Judiciário diante de tal confrontação.

O caso 03 traz a atuação do Ministério Público Estadual, em defesa do meio ambiente, contra a Prefeitura Municipal de Poá-SP. Novamente, o risco que ações propostas pelo Ministério Público trouxe para a moradia de inúmeras famílias, exigiu intervenção da Defensoria Pública, trazendo definições opostas de meio ambiente e cidade, o que exigia a busca por topoi correspondentes a tais noções.

No caso 04 visualiza-se a Defensoria Pública na sua atribuição de fiscalização de políticas públicas e de proponente de legislação no âmbito do direito à cidade. $A$ mudança de postura da Instituição em relação aos demais casos - em que deixa de 
ser reativa a uma emergência, passando a ser ativa e propositiva - revela outras nuances da disputa do direito à cidade, em que se mostra também outra posição de agentes como o Ministério Público e o Poder Judiciário.

Ao fim, o quarto capítulo é o de conclusão, em que se tenta extrair como se desenvolveu o uso e a aplicação do direito à cidade nos casos analisados. Primeiramente, avaliar de que modo o direito à cidade, cuja promoção é atribuição estatutária da Defensoria Pública de São Paulo, foi por ela tratado. Analisa-se, em casos concretos, em que medida a atuação institucional pode ajudar a construir um paradigma jurídico referenciado em cidades includentes e compromissadas com a justiça social.

Segundo, visualizar como os demais agentes escolhidos articularam suas noções sobre o referido direito, trazendo uma visão amadurecida e, especialmente, de como o Poder Judiciário responde a estas demandas. Assim, pretende-se que se traga uma percepção sobre a disputa e construção de direitos que seja mais próxima da realidade.

Por fim, busca-se avaliar as possibilidades no campo jurídico de que a concepção do direito à cidade numa ótica inclusiva e republicana seja consolidada e aplicada efetivamente, conferindo à parcela mais frágil da população o acesso aos bens e serviços da cidade. 


\section{CAPÍTULO 01 - A DEFENSORIA PÚBLICA E O DIREITO À CIDADE COMO ACESSO AOS BENS E SERVIÇOS DA CIDADE}

$\mathrm{Na}$ análise proposta sobre a disputa pelo direito à cidade, tomou-se como paradigma inicial a defesa formulada pela Defensoria Pública do Estado de São Paulo, por meio de seu Núcleo de Habitação. Assim, o presente capítulo traz uma contextualização sobre os conceitos formuladores da concepção de uma instituição como a Defensoria Pública, passando, posteriormente, a detalhar a experiência paulista, relatando a criação da Instituição no ano de 2006, a partir de uma mobilização de centenas de movimentos sociais. Esta dinâmica é importante para compreender que tipo de formulação do direito à cidade esta Instituição desenvolve como premissa e que será colocada à prova na prática cotidiana.

\subsection{O CONCEITO DE ACESSO À JUSTIÇA COMO FUNDADOR DA DEFENSORIA PÚBLICA}

A elaboração da Defensoria Pública tem relação direta com o debate do acesso à justiça - conceito multívoco - que pode ser simplificado como a necessidade de garantir às pessoas meios de reivindicar ao Estado proteção aos seus direitos. Inicialmente, sob uma concepção política liberal-individualista, entendia-se que a função do Estado era de não-interferência, exigindo-se que este apenas não permitisse que se infringisse o direito de acessar o Judiciário (CAPELLETTI; GARTH, 1988, p. 9).

A evolução do Estado de bem-estar social trouxe a previsão de inúmeros direitos sociais, sem que houvesse, entretanto, mecanismos que fizessem impor o seu respeito, os novos direitos sociais e econômicos passariam a meras declarações políticas, de conteúdo e função mistificadores (SANTOS, 2006, p. 167). Além disso, o aumento da complexidade social, com o aparecimento de demandas de caráter coletivo, o surgimento de novos conflitos sociais, por meio de grupos ditos minoritários, em busca de novos direitos sociais, ampliou a litigiosidade exigindo um novo raciocínio sobre o que se esperava do Poder Judiciário. 
Neste contexto, a sociologia passa a se debruçar sobre os obstáculos ao acesso efetivo à justiça, especialmente, a partir da década de 1960 em diversos países. Os estudos de Mauro Capelleti e Bryant Garth influenciaram pesquisadores brasileiros, os quais não estavam preocupados, inicialmente, com os novos direitos conquistados a partir dos anos 60 por grupos étnicos e sexuais, mas com a própria necessidade de expandir para o conjunto da população os direitos básicos aos quais a maioria não tinha acesso (JUNQUEIRA, 1996, p. 390).

O estudo a respeito do acesso à justiça alavancou como obstáculos a serem transpostos ${ }^{5}$ :

a) Custas Judiciais: neste ponto avaliam-se os elevados custos dos processos, incluindo os gastos com honorários advocatícios; a falta de êxito em causas de pequeno valor, as quais não teriam qualquer efetividade de busca de solução pelo Judiciário, considerandose que os gastos seriam maiores que o benefício alcançado e; a duração longa dos processos, que geram mais dispêndios;

b) Possibilidades das partes: as diferenças entre os litigantes, que possuem condições financeiras e estruturais diversas, o que impede de alguns disputarem processos por longos prazos em detrimento de outros; diferenças de nível educacional e cultural que trazem sérios obstáculos a que uma pessoa primeiro reconheça a existência de um direito juridicamente exigível; depois há o problema de ter conhecimento de como se ajuizar uma demanda; por fim, a disposição psicológica de enfrentar uma ação judicial, com procedimentos complexos, em ambientes hostis, carregados de tecnicismo. Adicione-se a vantagem do litigante habitual, ou seja, aqueles que sempre ingressam com ações em larga escala - a exemplo de grandes corporações ou bancos - que conseguem maior economicidade e formas mais estratégicas de atuar do que o litigante eventual, que esporadicamente ingressa com uma ação judicial.

c) Problemas especiais dos direitos difusos ou coletivos, que em razão de inúmeras pessoas os titularizarem simultaneamente, a 
exemplo de do direito à cidade ou ao meio ambiente, traz grandes dificuldades no exercício de sua defesa.

Diante das avaliações acima, criou-se o conceito das ondas renovatórias da justiça, em que os estudiosos classificam as tentativas de se superarem as referidas barreiras no mundo ocidental. Assim sendo, consideram a primeira onda renovatória a assistência judiciária em que se tenta superar as limitações econômicas das partes oferecendo justiça gratuita e o serviço de litigância; a segunda traz as tentativas de proporcionar representação jurídica para os interesses difusos e coletivos e; a terceira com o enfoque de acesso à justiça em sentido amplo, ou seja, não apenas por meio de acesso a processos judiciais, mas pela busca da melhor solução possível aos conflitos, pela solução extrajudicial de conflitos, pela educação para os direitos da população, por soluções que vão além do direito, por meio de outros profissionais de campos como a psicologia, assistência social, antropologia, etc.

Em diversos períodos, no Brasil, teve-se a preocupação com o acesso de pessoas de baixa renda aos sistemas judiciais, contudo isto se dava de forma caritativa com previsões legais de gratuidade de custas judiciais para o "réu pobre", a exemplo do Regulamento no 120 de 31 de janeiro de 1842 ou da atuação de advogados de forma gratuita -de que é exemplo a criação do Instituto de Advogados do Rio em 1870 para assistência judiciária de "indigentes" (MESSITE, 1968, p. 129130).

Após a primeira previsão constitucional da assistência judiciária, pela Constituição de 1934, aos poucos surgiram os primeiros serviços governamentais de assistência judiciária, a exemplo do Estado de São Paulo que, em 1935, passou a contar com advogados de plantão remunerados, sendo seguido pelo Rio Grande do Sul e Minas Gerais (MESSITE, 1968, p. 136). Em 1954, surge a primeira Defensoria Pública do país, no Estado do Rio de Janeiro, seguida pela Defensoria de Minas Gerais em 1976 (OLIVEIRA, 2007), em que os serviços de assistência judiciária passaram a ser feitos por servidores estatais de carreira.

É possível notar que a despeito de ter existido uma preocupação histórica com o acesso à justiça dos mais pobres, as iniciativas não possuíam escala a ponto de abarcar a maior parte da população, assim como estavam diretamente relacionadas apenas com os obstáculos da chamada primeira onda renovatória da justiça. As preocupações com o aprofundamento dos debates, em busca de uma justiça mais inclusiva e adequada para dar respostas aos conflitos sociais, surgiram no Brasil 
apenas a partir da década de 80 , permitindo o avanço das concepções sobre a Defensoria Pública.

\subsection{A DEFENSORIA PÚBLICA A PARTIR DA CONSTITUIÇÃO DE 1988}

A Constituição Federal de 1988 trouxe uma expansão de direitos sociais, prevendo, igualmente, suas garantias. A Defensoria Pública recebeu previsão constitucional, sendo considerada como instituição essencial à administração da Justiça, cabendo-Ihe a orientação jurídica e a defesa em todos os graus dos necessitados (art. 134, CF), assim como a assistência jurídica integral e gratuita aos que tivessem insuficiência de recursos foi alçada como direito fundamental do indivíduo (art. 5ำ, LXXIV, CF).

Tal marco foi significativo para o surgimento de diversas Defensorias Públicas no país, assim como para a promulgação da Lei Complementar Federal oㅡ 80/1994, a Lei Orgânica da Defensoria Pública, que organizou a Defensoria Pública da União, do Distrito Federal e dos Territórios e prescreveu normas gerais para sua organização nos Estados. Foi moldado, portanto, um modelo de acesso à justiça público, realizado por servidores de carreira, garantido constitucionalmente.

A primeira redação da Lei Orgânica apresentava uma noção de serviço no âmbito judicial e extrajudicial, entretanto, as funções institucionais ainda não permitiam uma defesa integral da pessoa de baixa renda, não havendo previsão de atuação em demandas coletivas, por exemplo. A extrapolação das barreiras legais era realizada pela via judicial, em que se admitia o uso de ações coletivas pela Defensoria Pública, garantindo-se a defesa adequada às pessoas carentes, o que pode ser visto pelas manifestações dos Ministros do Supremo Tribunal Federal Sepúlveda Pertence ${ }^{6}$ e Ellen Gracie ${ }^{7}$ (ORDACGY, 2011. p. 248).

Além disso, a implementação foi realizada de forma muito lenta. Conforme o I Diagnóstico Nacional da Defensoria Pública, produzido pelo Ministério da Justiça no ano de 2004, a "média de idade" da Defensoria Pública nas diversas unidades da Federação era de treze anos, sendo que alguns Estados, a exemplo de São Paulo,

\footnotetext{
${ }^{6}$ Ação Direta de Inconstitucionalidade nํ5ㅇ 55 MC/RJ (DJ de 16 /08/1991).

7 Reclamação Constitucional nº 2.466/RJ (DJ de 05/12/2003).
} 
Santa Catarina, Goiás e Rio Grande no Norte sequer tinham criado ou colocado a instituição em funcionamento (MINISTÉRIO DA JUSTIÇA, 2004, p.16).

Entretanto, a própria Reforma do Poder Judiciário no ano de 2004 fez parte de um conjunto de esforços para concretizar as Defensorias Públicas no Brasil. Inicialmente, na Emenda Constitucional no 45/2004 previu-se a autonomia da Instituição, permitindo sua desvinculação do Poder Executivo, como era a regra nacional. Foi iniciada, também, uma reforma da Lei Orgânica, incorporando aspectos do regime jurídico estadual da Defensoria Pública do Rio de Janeiro, que já contemplava autonomia institucional e, sobretudo, o projeto de lei do "Movimento pela Criação da Defensoria Pública de São Paulo" (VITTO, 2011, p. 218).

Tais estudos resultaram na Lei Complementar Federal no132/2009 a qual alterou profundamente a Lei Orgânica da Defensoria Pública, concretizando, no âmbito normativo, um enfoque de atuação condizente com a chamada terceira onda renovatória da justiça, ou seja, dedicada à efetivação da justiça da forma mais ampla possível. É o que pode ser observado pelo art. 4ํ da LC ํo 132/09:

Art. 4ํㅗ̃o funções institucionais da Defensoria Pública, dentre outras:

(...)

II - promover, prioritariamente, a solução extrajudicial dos litígios, visando à composição entre as pessoas em conflito de interesses, por meio de mediação, conciliação, arbitragem e demais técnicas de composição e administração de conflitos;

III - promover a difusão e a conscientização dos direitos humanos, da cidadania e do ordenamento jurídico;

IV - prestar atendimento interdisciplinar, por meio de órgãos ou de servidores de suas Carreiras de apoio para o exercício de suas atribuições;

$(\ldots)$

VI - representar aos sistemas internacionais de proteção dos direitos humanos, postulando perante seus órgãos;

VII - promover ação civil pública e todas as espécies de ações capazes de propiciar a adequada tutela dos direitos difusos, coletivos ou individuais homogêneos quando o resultado da demanda puder beneficiar grupo de pessoas hipossuficientes;

Antes disso, a Defensoria Pública já havia sido incluída na Lei no 7.347/1985 como uma das legitimadas a propor Ação Civil Pública, para defesa de interesses

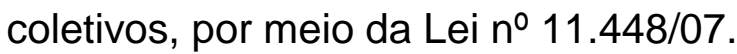


Finalmente, a Emenda Constitucional no 80/2014 fortaleceu a Defensoria Pública ao prevê-la na Constituição Federal como "instrumento do regime democrático, fundamentalmente, a orientação jurídica, a promoção dos direitos humanos e a defesa, em todos os graus, judicial e extrajudicial, dos direitos individuais e coletivos, de forma integral e gratuita, aos necessitados".

Este breve histórico, que não pretende ser exauriente, pretendeu demonstrar como o debate sobre acesso à justiça no Brasil permitiu que, ao menos legalmente, se avançasse de um modelo de mera prestação de serviço de litigância gratuito a um modelo de instituição pública voltada para a defesa das pessoas mais pobres em qualquer âmbito, desde os direitos humanos mais básicos, passando pelos direitos coletivos, priorizando sempre a resolução dos problemas de forma interdisciplinar e extrajudicial.

Perceba-se que foi elaborada a criação de: a) uma instituição pública com servidores de carreira pagos pelo Estado; b) que tem sua atuação definida a partir de um direcionamento para a defesa dos mais pobres; c) que possui todas as prerrogativas e garantias legais para a defesa integral de seu público; d) com legitimidade para a defesa dos direitos dos mais pobres de forma coletiva; e) que tem em sua lógica a busca de soluções interdisciplinares, que vão além do direito, priorizando soluções extrajudiciais; $f$ ) voltada à defesa dos direitos humanos e para a educação popular em direitos.

Tamanho mecanismo de implementação de direitos sociais traz análises otimistas sobre os seus alcances. Afirma-se que este eixo de trabalho voltado à visão coletiva, preventiva e indutora de novas realidades sociais, define o Defensor Público não mais como mero operador do direito, mas como agente de transformação social (BURGUER, BALBINOT, 2011, p. 3). No mesmo sentido (SADEK, 2014, p.20):

\footnotetext{
Em um país marcado por extremas desigualdades econômicas, sociais e culturais, os preceitos relativos à igualdade e à inclusão poderiam soar como pura abstração ou como componentes de uma carta de intenções. A possibilidade real, contudo, de transformação de mandamentos igualitários em realidade concreta encontra na Defensoria Pública o motor mais importante na lira pela efetivação dos direitos e pela prevalência da igualdade.
} 
O debate e a disputa social que ocorreu a partir do foco do acesso à justiça, permitiu a criação no Brasil de um modelo inovador de atuação no sistema de justiça. Em que pese o potencial de atuação de uma instituição com uma missão bem definida - a partir de um grupo social específico -trazer prognósticos tão otimistas como os citados acima, deve-se considerar que tais avaliações são, acima de tudo, feitas em abstrato, sendo necessário analisar em que medida a Defensoria Pública consegue cumprir seu papel a partir da sua atuação prática.

\subsection{A CRIAÇÃO DA DEFENSORIA PÚBLICA DE SÃO PAULO A PARTIR DA ARTICULAÇÃO COM CENTENAS DE ENTIDADES DA SOCIEDADE CIVIL}

A Defensoria Pública no Estado de São Paulo foi uma das últimas a serem criadas no Brasil, o que veio a ocorrer 16 anos após a promulgação da Constituição da República de 1988. O serviço de assistência judiciária já existia neste Estado, porém realizado pela Procuradoria Geral de Justiça, subordinada ao Governo do Estado de São Paulo. Não havia, portanto, autonomia funcional, administrativa ou orçamentária do serviço, o que dificulta o planejamento voltado para ampliação do serviço, assim como a atuação ainda era vinculada à judicialização.

A elaboração da Instituição somente ocorreu após diversas reivindicações sociais. Inicialmente, foi realizado um seminário desenvolvido pelo Núcleo de Estudos da Violência da USP em 1999, bem como foram feitas Audiências Públicas pela Comissão de Direitos Humanos da Assembleia Legislativa do Estado de São Paulo, o que foi seguido de novo seminário em 2002 (CARDOSO, 2010, p. 105 e 106). Porém, em 24 de junho de 2002, representantes de mais de quatrocentas entidades e movimentos sociais lançaram o "Movimento pela Defensoria Pública", que fomentaram o debate juntamente com operadores do direito, professores universitários e partidos políticos, culminando com um Manifesto pela Criação da Defensoria Pública. Em 09 de janeiro de 2006, o então Governador do Estado sancionou a Lei Complementar Estadual no 988/06, que criava a Instituição.

A intensa articulação entre o Sindiproesp - Sindicato dos Procuradores do Estado de São Paulo -, Associações de trabalhadores e de bairro, partidos políticos, Universidades, entidades religiosas, de luta pelas mulheres, negros, pessoas com 
deficiência, por moradia, educação, saúde, reforma agrária, direitos humanos, etc, trouxe um traço marcante na Lei Complementar Estadual no 988/06. Tais entidades, que compunham o Movimento de Criação pela Defensoria Pública, apresentaram seu próprio anteprojeto de lei, o qual possuía propostas como a defesa dos direitos difusos e coletivos; difusão do conhecimento dos direitos humanos; atendimento interdisciplinar; participação da sociedade civil na elaboração do Plano Anual de atuação; implantação de uma Ouvidoria Externa, como mecanismo de participação da sociedade civil na instituição, etc (CARDOSO, 2010, p. 114 e 115).

As propostas foram acolhidas no Projeto de Lei oficial, o que culminou com uma legislação avançada, em que a interação da sociedade civil na estrutura da Instituição foi extremamente estimulada, permitindo a criação de uma Lei Orgânica estadual que seria referência em nível nacional, que resultaria na Lei Complementar ํㅡ132/2009, conforme exposto anteriormente.

\subsubsection{A previsão de um Núcleo Especializado em Habitação e Urbanismo para a Defensoria Pública do Estado de São Paulo}

A interação da sociedade civil organizada neste processo de criação foi um fator relevante para justificar a previsão de uma Núcleo Especializado na defesa de direitos relacionados com habitação e urbanismo no âmbito da Defensoria Pública do Estado de São Paulo. Neste espaço de debates, formulações e concretizações acerca de qual a feição que deveria ter uma Defensoria Pública para a população vulnerável do Estado de São Paulo, participaram diversos movimentos e instituições que tinham como finalidade a luta pela moradia/cidade. O Manifesto pela criação da Defensoria Pública foi assinado pelas seguintes instituições e movimentos: Associações de Construção por Mutirão; 26 de julho; Casarão; Madre de Deus; Associação Unificada dos Loteamentos da Zona Leste (SP); Unificação das Lutas de Cortiço; União dos Movimentos de Moradia; Centro Gaspar Garcia de Direitos Humanos; Conectas Direitos Humanos; Instituto Pólis; Escritório Modelo "Dom Paulo Evaristo Arns" da Faculdade de Direito da PUC, além de diversas Associações de bairro8.

Todas estas Associações, ONG's, Movimentos Populares, Escritório Universitário e demais instituições estavam em um período de recém promulgação do

8 Lista completa dos subscritores do manifesto na obra de Luciana Zaffalon Leme Cardoso (2010, p. 109 a 112) 
Estatuto da Cidade em 2001 e de criação do Ministério das Cidades em 2003, ou seja, em plena efervescência das conquistas de maior magnitude após a Constituição de 1988 para o direito à cidade. $O$ cerne destes debates foi trazido para o movimento pela criação da Defensoria Pública, o que resultou na previsão no art. 52, da Lei Complementar Estadual 988/06, do Núcleo Especializado de Habitação e Urbanismo - NHABURB, que teria como funções, dentre outras, propor medidas judiciais e extrajudiciais, na defesa de interesses individuais, coletivos ou difusos, assim como estimular o intercâmbio com Defensores Públicos.

O NEHABURB foi regulamentado pela Deliberação do Conselho Superior da Defensoria Pública (CSDP) № 105/2008, o qual definiu o órgão da seguinte forma:

\footnotetext{
Artigo 3ํ - O NHABURB é órgão de execução e de atuação da Defensoria Pública do Estado de São Paulo de caráter permanente e tem como missão primordial de prestar suporte e auxílio no desempenho da atividade funcional dos membros da instituição sempre que a demanda for coletiva ou em casos individuais de repercussão geral, referente direta ou indiretamente, ao direito à Moradia digna e o direito à Cidade.
}

O NHABURB, portanto, tem como função central apoiar defensores públicos, assim como exercer diretamente a defesa do direito à moradia digna e do direito à cidade para a população mais pobre. Para entender qual o conteúdo destes conceitos normativos abertos, o Estatuto da Cidade é elucidativo ao definir o direito à cidade sustentável como o direito à terra urbana, à moradia, ao saneamento ambiental, à infraestrutura urbana, ao transporte e aos serviços públicos, ao trabalho e ao lazer, para as presentes e futuras gerações ${ }^{9}$.

Considerando-se a missão da Defensoria Pública em conferir acesso à justiça aos mais pobres, tendo como o objetivo legal conferir primazia à dignidade da pessoa humana e à redução das desigualdades sociais ${ }^{10}$, pode-se interpretar que o direito à cidade para esta Instituição representa lutar pelo acesso da população vulnerável aos bens e serviços da cidade, voltando o uso da propriedade urbana para o bem coletivo.

Além disso, a disputa por esta concepção de direito à cidade deve ser feita em âmbitos de grande repercussão e complexidade, inserindo a Defensoria Pública como uma instituição que pretende ser um grande ator nesta disputa no campo jurídico. $O$

\footnotetext{
${ }^{9}$ Art. ㄴo, l, da Lei no $10.257 / 2001$.

${ }^{10}$ Art. 3-A, I, da Lei Complementar Federal no 80/1994.
} 
objetivo normativo que se apresenta é de criar uma instituição pública, com atuação permanente, na disputa pela definição deste direito à cidade, conforme indica o art. $6^{\circ}$ da Deliberação CSDP № 105/2008:

Artigo $6^{\circ}$ - As atribuições do NHABURB no âmbito judicial são de caráter excepcional, subsidiário e suplementar, justificando-se por critérios de complexidade e amplitude da questão ou por ausência de Defensor Público natural lotado na comarca, sendo que neste último caso pode haver uma atuação com o Coordenador da Regional correspondente.

$\S 1^{\circ}$ - Os critérios de complexidade e a amplitude serão decididos pelo plenário considerados os seguintes aspectos, entre outros:

a) amplitude geográfica da demanda;

b) número de famílias envolvidas;

c) novação da tese jurídica e ausência de precedentes;

d) tratar-se de ZEIS ou operação urbana consorciada.

O modelamento formal realizado busca, também, munir a Instituição de todos os modos de atuação possíveis para a confrontação de sua proposta de defesa do direito à cidade e da moradia digna. Não bastaria a defesa judicial ou extrajudicial, mas a educação e conscientização da população, o exercício de fiscalização dos Poderes Públicos, realizar propostas legislativas e de planejamento de políticas públicas, atuar em Cortes Internacionais, etc. Destaca-se, portanto, o art. 4ํ da Deliberação CSDP no 105/2008, que dá a dimensão das possibilidades de atuação da referida instituição:

Artigo 4ำ- São atribuições do NHABURB:

I - informar, conscientizar e motivar a população carente, inclusive por intermédio dos diferentes meios de comunicação, a respeito de seus direitos e garantias fundamentais; em coordenação com a assessoria de comunicação social e a Escola Superior da Defensoria Pública;

II - estabelecer permanente articulações com núcleos especializados ou equivalentes de outras Defensorias Públicas na área da habitação e urbanismo para definição de estratégias comum em assuntos de âmbito nacional e para intercâmbio de experiências;

III - contribuir no planejamento, elaboração e proposição de políticas públicas que visem a erradicar a pobreza e a marginalização, bem como a reduzir as desigualdades sociais; 
IV - propor e acompanhar propostas de elaboração, revisão e atualização legislativa na área de habitação e urbanismo;

V - realizar e estimular o intercâmbio da Defensoria Pública com entidades públicas e privadas ligadas à área da habitação e urbanismo;

VI - representar a instituição perante conselhos de direitos, por qualquer de seus membros, mediante designação do Defensor Público-Geral do Estado; VII - contribuir para a definição, do ponto de vista técnico, das ações voltadas à implementação do Plano Anual de Atuação da Defensoria Pública quando disser respeito à defesa do direito à Moradia digna e do direito à Cidade;

VIII - coordenar o acionamento de Cortes Internacionais em relação a casos de violação do direito à Moradia e à Cidade;

IX - propor medidas judiciais e extrajudiciais para a tutela de interesses difusos, coletivos e individuais homogêneos relativos ao direito à Moradia digna e ao direito à Cidade.

As diversas instituições e movimentos que reivindicam o direito à moradia e à cidade, que participaram da criação da Defensoria Pública, necessitavam efetivar os marcos normativos estabelecidos - especialmente no Estatuto da Cidade percebendo que a mera previsão legal de direitos não seria suficiente para sua consagração. Assim, contribuíram para a formulação de uma instituição com todos os instrumentos necessários para a defesa de uma ordem jurídico-urbanística imbuída de justiça social. O NHABURB, portanto, assumiria um protagonismo no exercício da defesa de tais direitos, que possuíam movimentos sociais muito bem articulados e que participaram de sua formulação.

O resultado deste intercâmbio foi que, nos últimos meses do ano de 2006, o Núcleo de Habitação passou a funcionar efetivamente e em 24 de fevereiro do ano de 2007, foi realizada a chamada "1ā Jornada em Defesa da Moradia Digna", com a participação de mais de 2 mil pessoas oriundas de assentamentos precários. O evento foi elaborado em torno de uma agenda de atuação da Defensoria Pública e de entidades como a Assessoria Técnica Caicó, o Centro Gaspar Garcia de Direitos Humanos, o Instituto Pólis, a Pastoral da Moradia, a União dos Movimentos de Moradia - UMM e as universidades, a exemplo da Uninove e do Escritório Modelo "Dom Paulo Evaristo Arns" da Faculdade de Direito da PUC, além da Associação de Notários e Registradores do Estado de São Paulo - ANOREG/SP (SÃO PAULO, 2008, p. 17). 
A Jornada foi organizada em Pré-Jornadas, mediante a visita em quatro comunidades: Favela do Moinho, Jardim Celeste, Brasilândia e Vila Itororó, com o intuito de conhecer a realidade daquela população, conversar com lideranças, orientar sobre documentação de casos jurídicos e mobilizar para a participação na Jornada. Entre os objetivos da Jornada estava a criação de um marco na luta pela moradia digna, encaminhando casos individuais e coletivos a serem solucionados, criação de jurisprudência sobre o tema, divulgação dos direitos à moradia digna, a ampliação dos profissionais envolvidos no tema e a apresentação do NHABURB para seus participantes.

Para além de todo o aparato burocrático que se tinha organizado, a interação dos próprios Defensores com os movimentos de luta pela cidade e por moradia permitiu o modelamento e o fortalecimento do próprio raciocínio institucional sobre o direito à cidade, voltado aos pobres e com referência no Estatuto da Cidade. Neste estudo, aplica-se, em analogia, a opinião de Evorah Lusci Costa Cardoso (2012, p.2223) de que o desenho institucional influencia a mobilização social jurídica, assim como a presença de uma forte mobilização social em torno do discurso dos direitos pode influenciar a agenda e o funcionamento de uma instituição. Do mesmo modo, compreende-se que o desenho institucional não diz respeito à formatação burocrática de um órgão, mas às relações cotidianas entre agentes, o tipo de retórica utilizado pela instituição, ou seja, toda a dinâmica que formata o constante processo de construção das instituições.

Assim sendo, a contribuição de tais movimentos pela cidade, inclusive acadêmicos, na implementação de um Núcleo de Habitação da Defensoria Pública de São Paulo, não se limitou à previsão legal, mas sim ocorreu na interação diária com os recém-defensores, na construção de um discurso e um perfil institucional ligado diretamente ao debate da reforma urbana e à função social das cidades.

Definido, portanto, um Núcleo Especializado de Habitação e Urbanismo, vinculado às aspirações de movimentos de luta pela cidade, com a missão institucional de fazê-lo no interesse dos mais pobres, garantindo o acesso aos bens e serviços da cidade, gerava-se uma grande expectativa sobre os efeitos de uma instituição pública com tal formatação. 


\section{Capítulo 02 - O DIREITO COMO CAMPO JURÍDICO E O USO DA TÓPICA NA DISPUTA PELO DIREITO À CIDADE}

\subsection{DA LIMITAÇÃO QUE O DOGMATISMO JURÍDICO TRAZ PARA ANÁLISES SOBRE O DIREITO À CIDADE}

O Núcleo de Habitação e Urbanismo - NHABURB surge como mais um agente no sistema de justiça ${ }^{11}$ com a missão de aplicar o raciocínio jurídico do Direito Urbanístico, porém, inserido em uma cultura jurídica baseada no conceito de propriedade. A proposta de atuação da Defensoria Pública no campo da habitação e urbanismo visa à redução da pobreza, por meio de intervenções jurídicas que garantam o direito à moradia e a cidades inclusivas e democráticas. A tentativa de implementação de tal projeto, portanto, ocorre pelo Direito - seja de forma judicial ou extrajudicial - e exige uma avaliação crítica sobre o Direito e suas finalidades, estabelecendo pressupostos para compreensão do papel da Defensoria Pública na defesa do direito à cidade.

A escola do positivismo jurídico, surgida no século XIX, buscou definir o Direito a partir da norma jurídica, trazendo o conceito de sistema jurídico como conjunto de normas do ordenamento jurídico. O direito escrito foi ganhando mais importância, ante a existência dos Estados nacionais e a fonte de poder se deslocava para o conceito de nação, não mais em um rei que representaria uma tradição ou divindade. Esta alteração representava a possibilidade de se criar o Direito, tornando-o mutável, por foça de um ato de vontade (FERRAZ, 2003, p. 74). Este ato de criação por meio da lei é delegado para o Poder Legislativo, buscando-se uma neutralidade política do Poder Judiciário, o que aumenta a produção normativa como fonte primária do Direito.

Por outro lado, a tentativa de sistematizar o conjunto de normas produzido, criando conceitos, categorias de análise, com coerência, organização e estrutura lógica, faz surgir a Ciência Dogmática do Direito. A dogmática jurídica, para Rafael Bielsa (1961, p. 69-70, apud WARAT, 2002, p. 17) passa a se apresentar como a

\footnotetext{
11 No entender de Maria Tereza Sadek (2010, p. 9-10) "sistema de justiça é mais amplo do que poder judiciário. A rigor, o juiz é apenas uma peça de um todo maior. O sistema de justiça envolve diferentes agentes: o advogado, pago ou dativo; o delegado de polícia; funcionários de cartório; o promotor público e, por fim, o juiz."
} 
tentativa de construir uma teoria sistemática do direito positivo, sem formular nenhum juízo de valor sobre este, convertendo-a em uma mera ciência formal.

Havia uma pretensão de se formular uma ciência jurídica em que o Direito seria concebido como um sistema fechado e autônomo, ou seja, desprovido de influências históricas, políticas, sociais, econômicas, psicológicas, etc, tendo seu desenvolvimento explicado apenas pela dinâmica interna entre as normas. Deste modo, seria possível estabelecer o direito como um sistema neutro, universal e autônomo que, por meio de seus métodos de aplicação normativa, apresentaria soluções jurídicas para todo e qualquer conflito social.

A dogmática, segundo Warat (2002, p. 17), se baseia no pressuposto de que não há mais Direito que o ordenamento jurídico estabelecido através das leis validamente ditadas e vigentes, assim, se vincula diretamente com o positivismo, limitando sua função à interpretação da lei pelo método exegético. Não é incomum perceber-se a avaliação do processo da produção de normas como uma relação causal entre a vontade do Legislador e o Direito como norma legislada (FERRAZ, 2002, p. 17), o que tem forte influência até os dias atuais e bastante aceitação no imaginário social.

A assunção acrítica do Direito por uma lógica dogmática, sem maiores detalhamentos, faz crer que a função da Defensoria Pública - ao articular o direito à cidade - se limitaria a disputar a interpretação de leis, ou seja, em formar o convencimento dos magistrados na aplicação do sistema de normas. Assim sendo, esta nova instituição pública, comprometida com uma visão do direito à cidade, a partir da lógica dos menos favorecidos, teria como grande missão o engajamento técnico, de articular os melhores argumentos jurídicos para defender seu público-alvo.

É relevante que tal pressuposto do dogmatismo seja superado para que não se incorram em visões do Direito que o analisem como um conjunto de normas coerentes, que carecem de interpretação, condensando as análises dos entraves do direito à cidade em duas ordens. A primeira seria que o problema reside na falta de legislação adequada, sendo necessária maior produção legislativa que especifique competências, sanções ou que regulamente direitos existentes no ordenamento, por exemplo como o direito à moradia. A imperatividade de regulamentação viria de uma abstração das normas, que não teriam concretude suficiente para serem aplicadas.

O segundo tipo de apreciação entende que os obstáculos à efetivação do direito à cidade estão na interpretação falha dos magistrados e Tribunais de Justiça, que 
conduz a inúmeros estudos sobre jurisprudência, a partir de uma lógica estatística, em que se verifica o recepcionamento de um direito pela procedência ou improcedência dos pedidos nos processos. Verifica-se que, nestes estudos, muitas conclusões são genéricas e indicam como justificativa para a inefetividade do direito à cidade o reacionarismo do Poder Judiciário ou o conhecimento sedimentado do Direito Civil, baseado na propriedade, por parte dos magistrados, em contraposição ao ramo do Direito Urbanístico, que seria pouco conhecido e ainda incipiente.

Este tipo de leitura tem sua relevância, porém, apresenta noções parciais sobre a realidade, resultando em explicações que são mais relativas ao âmbito político, do que relativas ao próprio funcionamento do Direito. Para que se possa analisar a questão sob outra perspectiva, que demonstre como se desenvolvem estas questões envolvendo o direito à cidade no âmbito jurídico, é que se apresenta a concepção de Direito como campo jurídico, trazida por Pierre Bourdieu.

\subsection{O DIREITO COMO CAMPO JURÍDICO}

Pierre Bourdieu estuda as relações de poder na sociedade a partir dos sistemas simbólicos, que seriam instrumentos de conhecimento do mundo objetivo e de sua construção como formas simbólicas. As práticas sociais, na medida em que vão se tornando mais complexas, em que certas relações vão se tornando cada vez mais especificadas e dotadas de tecnicidades próprias, passam a ganhar relativa autonomia, diferenciando-se e gerando campos como a arte, religião, língua, ciência, direito, política, etc. Deste modo, o poder de construção da realidade, dentro de cada campo, estabelecendo um sentido imediato do mundo, seria o denominado poder simbólico (BOURDIEU, 2012, p. 09). Os atores sociais, portanto, passam a disputar o controle da produção de sentido para realidade no interior de cada um destes campos.

Os sistemas simbólicos são estruturados e estruturantes, ou seja, são previamente estabelecidos pelas conjecturas sociais como a história, a cultura, mas também constroem novos formatos e sentidos, organizando a percepção que as pessoas possuem da realidade. Assim, a realidade social não é gerada simplesmente pelas condições materiais de um local e tempo, nem é elaborada pela vontade dos indivíduos, de forma autônoma e consciente. Este entendimento é formado pela categoria do habitus, que seria a mediação entre as condições sociais existentes e as ações individuais, historicamente construídas, auxiliando no entendimento de uma 
homogeneidade de grupos que tenham uma trajetória social em comum (SANTOS, 2011, p. 92). Na definição de Adjair Alves (2010, p. 140):

O conceito de habitus desempenha o papel de elo articulador entre três dimensões fundamentais de análise: a estruturas das posições objetivas, a subjetividade dos indivíduos e as situações concretas de ação. E ainda, a posição que cada sujeito ocupa na estrutura das relações objetivas propicia um conjunto de vivências típicas que se consolidaria na forma de habitus adequada a sua posição social. O sujeito agirá na sociedade em função deste habitus, como um membro típico de um grupo social ocupando a posição que Ihe compete na estrutura social, colaborando para reproduzir as propriedades do seu grupo social de origem e as estruturas na qual foi formado.

O habitus representa uma conciliação das visões de agência e estrutura, ao entender que a produção da realidade social é conduzida pela vontade de indivíduos, mas que tem suas escolhas profundamente determinadas pela classe social que ocupam. O homem nem é completamente determinado pelas estruturas sociais, nem é completamente livre no agir social. Assim, todo o aparato histórico que envolve a posição social de um indivíduo, como visão política, crenças, tradições, estratégias de ação, etc, são incorporadas pelas pessoas, que agem socialmente, contudo, com tais constrições.

A categoria do habitus, portanto, explica como as estruturas de poder ou de dominação econômica, por exemplo, são reproduzidas sem que os indivíduos tenham consciência, fazendo parte de sua própria natureza. Assim, os sistemas simbólicos organizam as percepções do sujeito e sua linguagem, o que os direciona para a reprodução das estruturas de poder e dominação social. No dizer do próprio Bourdieu (2012, p.10), os símbolos são instrumentos por excelência da integração social, enquanto instrumentos de conhecimento e comunicação, tornando possível o consensus acerca do sentido do mundo social que contribui para a reprodução da ordem social.

Os espaços de relações sociais em que as atividades se tornam complexas a ponto de se serem relativamente autônomas, produzindo-se bens sociais específicos, é o que se denomina campo. No campo é onde se hierarquizam as produções de bens simbólicos, das instituições e pessoas, classificando-se os padrões culturais produzidos. No interior do campo, portanto, é que ocorre a disputa pelo predomínio 
desta produção de visões sociais - lembre-se dos símbolos como formadores do conhecimento e da comunicação - havendo a violência simbólica, quando os dominados são submetidos ao padrão estabelecido.

O campo jurídico, por sua vez, é o espaço em que há a concorrência entre os agentes e instituições para o exercício da competência social e técnica de interpretar um corpus de textos que consagra a visão legítima, justa do mundo social (BOURDIEU, 2012, p. 212). Há uma verdadeira disputa pelo monopólio de dizer o Direito, pois as práticas e discursos jurídicos vão sendo produzidos, a partir de uma relação de forças que forma a estrutura deste campo, definindo hierarquias e toda sua lógica de funcionamento. A luta é pela apropriação do poder simbólico no campo jurídico, permitindo a imposição de uma linguagem e modo de conhecimento, que resulta na imposição de uma ordem social.

A determinação de ritos, procedimentos codificados, linguagem técnica, vão formando a concepção de que o Direito possui uma autonomia em relação a demais sistemas sociais. Por outro lado, a linguagem feita por palavras impessoais ou construções passivas, ajudam a formar a noção de neutralidade do direito. Não menos importante é a formação de um sentido universalista do direito pela linguagem, que tenta transpassar uma percepção da existência de algum consenso ético social.

O que a alusão do Direito como campo jurídico ensina é que há uma verdadeira divisão do trabalho entre os aplicadores do direito para a venda de bens e serviços jurídicos ${ }^{12}$, a partir da referida disputa. Advogados, juízes, promotores, defensores, notários, todos os atores do meio jurídico confrontam visões de mundo, para imporem sua interpretação sobre o direito. O que define o formato deste campo é a força dos teóricos e dos práticos do direito, fazendo prevalecer um monopólio no poder de dizer o Direito.

Assim, este "mercado" de bens e serviços jurídicos é controlado por este corpus de atores jurídicos que produz a demanda, constituindo problemas jurídicos, traduzindo-os na linguagem do Direito, analisando as chances de êxito. Um dos poderes mais significativos dos lawyers é o trabalho de expansão e amplificação de disputas, ou seja, um trabalho propriamente político de manipular as aspirações

12 Bourdieu trata o Direito como um campo em que há intensas relações de poder pelo seu monopólio, entretanto, aborda que esta disputa também é por um mercado de bens e serviços jurídicos, o que resulta em diversos termos econômicos como, mercado, venda, demanda ou capital simbólico. 
jurídicas para fazê-las crescerem ou diminuírem como pretensão, controlando o acesso ao campo jurídico (BOURDIEU, 2012, p. 232).

O raciocínio de Bourdieu revela que há uma disputa pelo domínio do poder simbólico, de definir as noções jurídicas, a qual impõe uma visão de mundo, que é assimilada pelos dominados como uma verdade. Concepções, por exemplo, do direito de propriedade como um direito fundamental do ser humano, dotado de amplos poderes para ser defendido contra qualquer pessoa que tente violá-lo, consolidam-se, impondo uma leitura de mundo.

O controle da demanda pelos participantes do jogo jurídico é que definirá se um conceito novo como o direito à cidade terá força jurídica e o que definirá isso será a conformação entre estes teóricos e operadores jurídicos, a partir de sua influência e relevância. Torna-se importante, nesta via, analisar qual o tipo de narrativa proposta pela Defensoria Pública, considerando-se que seu surgimento, a partir do ano de 2006, significou a surgimento de um novo disputante no campo jurídico na esfera do direito à cidade e à moradia.

No estudo dos casos concretos foram selecionados casos com atores jurídicos diversos para permitir analisar a construção retórica de cada um, observando-se não apenas qual a visão sobre o Direito se sobrepõe, mas destacando também que esta disputa cria a ordem, tendo impacto na formação do espaço urbano. Uma decisão judicial resolve os conflitos, mas também traz o poder de nomeação ou instituição, que distribui capital simbólico aos agentes envolvidos, consagrando definições, grupos, transformando o mundo social.

Deve ser ressalvado, entretanto, que o Direito não é construído pela decisão judicial, esta apenas define os limites - por ter a qualidade de ser a palavra oficial instituindo o que foi construído por todos os agentes jurídicos envolvidos. No dizer de Bourdieu:

A interpretação judicial é resultado de uma luta simbólica entre profissionais dotados de competências técnicas e sociais desiguais, portanto, capazes de mobilizar, embora de modo desigual, os meios ou recursos jurídicos disponíveis, pela exploração das "regras possíveis", e de os utilizar eficazmente, que dizer, como armas simbólicas, para fazerem triunfar a sua causa; o efeito jurídico da regra, quer dizer, a sua significação real, determinase na relação de força específica entre os profissionais (...). 
As condições desiguais, portanto, dos operadores jurídicos e de seus teóricos, são determinantes para a conformação do campo jurídico. Entretanto, há outro fator a ser considerado, que é a proximidade de interesses que une os agentes que detém o poder político, econômico ou estatal, que se reflete nos agentes jurídicos. Há uma afinidade dos habitus, em virtude de origens semelhantes de costumes, visão de mundo, escolarização, que fazem com que haja grande probabilidade de a forma de dizer o direito favoreça os dominantes. Nisto reside o grande desafio de fazer preponderar um direito à cidade que tenha como referência a melhoria das condições de vida da população mais pobre.

O entendimento de que as opções pessoais dos operadores - especificamente dos juízes - influem nas decisões judiciais é partilhado por Luís Roberto Barroso (2010, p. 30-34), que afirma que os valores e a ideologia do magistrado ou a interação entre os atores jurídicos, por exemplo, são determinantes para o resultado de uma causa.

A noção de Direito como campo jurídico, portanto, tem extrema relevância para compreender como o direito à cidade passa a ser disputado, refutando-se análises que o considerem como um dogma do sistema (seja princípio jurídico, direito fundamental ou social), que será avaliado por um silogismo, conduzindo o julgador à decisão do caso concreto. Na verdade, o direito à cidade é uma construção multívoca, que confere espaço para expressões tanto por parte de moradores de assentamentos informais, de periferias, favelas, mas também por setores das classes médias urbanas, profissionais como arquitetos, engenheiros, advogados ou atores do mercado imobiliário e financeiro. Todos estes significados são colocados em confronto pelas instituições e profissionais, que constroem a forma de conhecimento e comunicação do mundo jurídico.

Com esta perspectiva, demonstra-se como o Direito é estruturado por relações de poder, o que implica admiti-lo como um âmbito eivado de construções ideológicas, mascaradas pelo discurso jurídico. Cumpre anotar que o discurso jurídico possui ideologia, primeiro, ao ocultar as relações de poder por meio das vestes da universalidade, neutralidade e autonomia; depois, porque o discurso jurídico pressupõe decisões que contém fatores políticos, socioculturais, econômicos, históricos (BITTAR, 2016, p. 670) que tentam impor a ordem dominante.

O estabelecimento do Direito como campo de disputa ideológica pela dominação de seu poder simbólico é importante para entender como o direito à cidade 
é disputado, como ele se forma no meio jurídico e se transforma. Esta lógica permite encontrar outro paradigma em que se possa analisar a disputa pelo direito à cidade em casos da Defensoria Pública - cientes de quais valores e interesses o discurso jurídico de cada instituição representa. Este é um passo essencial para compreender os reais motivos das limitações do alcance do direito à cidade proposto pela Defensoria Pública.

\subsection{A TÓPICA JURÍDICA EM THEODOR VIEHWEG}

A relação entre agentes no campo referente ao Direito é uma disputa de discursos jurídicos, em que se busca o poder de nomeação, criando o Direito. Este se revela, portanto, como uma estrutura dinâmica, multívoca e em estágio de constante criação. Portanto, sua definição passa a ser feita posteriormente, pelos operadores jurídicos e não de forma antecipada na definição dos marcos legais. Abre-se maior importância para a tarefa decisional, em que o julgador não tem a simples tarefa de buscar a verdade dos fatos por meio de análises dedutivas de dogmas, mas o dever de conduzir uma troca comunicacional que gere consensos formadores de direitos.

O trabalho de Theodor Viehweg sobre tópica jurídica elucida como funciona o pensamento dos seus operadores em busca da decisão de problemas complexos e de difícil solução. Este enfoque é necessário, pois a reflexão a respeito da técnica de pensamento dos juristas possibilita um melhor entendimento dos casos concretos a serem observados, refutando-se o pensamento sistemático típico do dogmatismo jurídico, revelando um pensamento por problemas desenvolvido pelo agir comunicacional.

O dogmatismo jurídico, explica Luis Alberto Warat (2002, p. 17-19), lastreia-se em três etapas de aplicação: a) estabelecimento do direito positivo estatal, válido e vigente, como o único existente; b) fixação de dogmas jurídicos, ou seja, pressupostos inquestionáveis, definindo princípios, conceitos ou categorias extraídas dos textos normativos; c) sistematização deste conjunto de normas para aplicação em todos os casos conflituosos existentes. Assim, o Direito dogmático utiliza tal sistematização para viabilizar as decisões, partindo-se de um pensamento abstrato, isolado da situação concreta. Neste procedimento, tomam-se como pressupostos os axiomas estabelecidos, aplicando-se um método dedutivo, em que se parte da premissa maior 
para a menor, trabalhando somente a partir dos planos sintático e semântico, chegando, finalmente à conclusão da melhor solução para o caso concreto.

Este modelo de raciocínio do Direito, Theodor Viehweg define como pensamento sistemático. O referido jusfilósofo teve como cerne de sua investigação uma análise sobre a estrutura da Jurisprudência, buscando apresentar uma forma diferente de pensar a Ciência Jurídica, ao questionar a concepção de que o Direito teria como método um pensamento sistemático. Viehweg demonstra que 0 dogmatismo tem o problema da necessidade de julgar todos os casos (vedação ao non liquet), pois gera a necessidade do sistema apresentar respostas para toda a complexidade humana, o que se torna incompatível com um modelo baseado em dogmas. Assim, para que o sistema mantenha sua legitimidade social, deve sofrer constante modificação pela interpretação, o que prejudica o rigor da dedução (ROESLER, 2004, p. 168).

Desta forma, o sistema lógico-dedutivo, isolado de quaisquer valores, que chegaria a soluções para todos os casos não se comprovaria na prática. Na práxis jurídica, a estrutura de pensamento seria problemática, ou seja, teriua como a maior preocupação a solução do problema, apresentando como finalidade fundamental a implementação da justiça. Assim, não há soluções prontas antecipadamente, por meio de um sistema lógico, sendo necessário a busca da decisão mais adequada a partir de um processo argumentativo, que ocorreria por meio da tópica.

A tópica é uma técnica do pensamento que se orienta para o problema, em que diante de uma aporia - falta de um caminho ou uma situação problemática que não é possível eliminar - apresenta indicações de como se comportar nestas situações, encontrando uma saída (VIEHWEG, 1979, p. 35). Em acepção estrita, a tópica seria uma teoria dos lugares comuns e em acepção ampla seria uma teoria da argumentação e dos raciocínios dialéticos (FERRAZ JR, 2003, p. 328).

A tópica é um estilo de pensamento em que, a partir de um problema concreto, busca pressupostos para resolvê-los por meio dos "lugares comuns", ou seja, pontos de partida em que haja consenso entre as partes em conflito. Diante deste acordo argumentativo, segue-se para a formulação de novos consensos, por meio da dialética, até que se chegue a uma solução para o caso concreto.

Os lugares comuns são o que Viehweg denomina topoi (denominação no plural, pois no singular chama-se topos), os quais são flexíveis, provisórios e não dispostos hierarquicamente, cuja função precípua é servir a uma discussão por via do 
fornecimento de premissas que orientam o raciocínio (PINHO, 2016, p. 11). Assim, colocando-se o problema como o centro, buscam-se pressupostos selecionando diversos sistemas diferentes, para que haja uma construção dialética entre as partes, para que formulem novos conceitos, até que se chegue à resposta.

Perceba-se que no pensamento sistemático há dogmas pré-definidos e estáveis, inseridos em um único sistema, devendo chegar a uma conclusão pela dedução. Para Viehweg, o pensar sistemático tem a falha de não apresentar respostas quando o caso se mostra insolúvel. Como os pontos de vista já estão definidos, a questão se trata de selecionar os problemas que podem ser respondidos pelos pressupostos adotados, pois caso não se enquadrem, são rejeitados.

No pensamento problemático trabalha-se com o pensamento situacional, de forma pragmática, para se enfrentar as aporias. O problema é utilizado como ponto de referência para que se busquem topoi apropriados, destinados à construção de uma decisão que seja legitimada perante os debatedores, pois formulada a partir de argumentação racional visando ao consenso. $O$ debate pode tomar, por exemplo, uma norma jurídica como um topos, mas esta não teria um sentido predeterminado, pois este seria construído pela argumentação, tendo como referência o problema.

A tópica ingressaria no sistema jurídico, segundo análise de Cláudia Roesler (2004, p. 159 e 161) nos seguintes momentos: a) necessidade de adaptação social aos valores de cada momento histórico, o que se faria pela interpretação; b) o uso da linguagem natural, ou seja, como a linguagem apreende diversos pontos de vista inventivos, transformando os conceito, negando a ideia de que o conteúdo semântico dos textos legais estaria completamente fixado a priori; c) a escolha dos princípios ou axiomas fundamentais, bem como dos conceitos fundamentais é arbitrária, necessitando de justificação a partir de uma necessidade concreta; d) definição dos fatos que são juridicamente relevantes; e) escolha dos métodos de aplicação do direito.

As situações acima descritas indicam que, quando as deduções do sistema dogmático chegam a conclusões completamente inadequadas ao pensamento dominante de uma época, por exemplo, passa-se a pensar a partir do problema, por meio da tópica. Esta observação aponta que o pensamento problemático não afasta o sistema dogmático, ao contrário, utiliza-o, assim como usa outros sistemas, especialmente porque, nos momentos descritos, o operador do direito acaba por 
posicionar o problema como centralidade, pois o dogmatismo não conduz às respostas necessárias.

Outra questão relevante é notar como a fixação de conceitos fundamentais e a articulação discursiva são arbitrários e desenvolvidos a partir do problema. A título ilustrativo, basta imaginar como um julgador poderia solucionar um conflito fundiário em que estivessem em oposição o direito ao meio ambiente e a função social da cidade disposta no art. 182 da Constituição Federal. Diante da indeterminação dos conceitos a serem utilizados ou da falta de regras claras que determinem o que seria uma "ponderação de valores", os operadores jurídicos acabam por selecionar os conceitos que melhor lhes fornecem argumentos, assim como articulam o discurso para conduzir o caso para seu senso de justiça.

No capítulo em que serão analisados os casos concretos, será abordada esta questão, demonstrando-se que em uma situação como em uma disputa fundiária, o pressuposto tomado pode ser a defesa de uma cidade democrática, da ordem pública, do poder da administração ou do meio ambiente, todas podendo ser inconciliáveis, trazendo a chamada aporia. Nesta situação, fica claro como os operadores acabam se utilizando de um pensamento problemático e não dogmático. Porém, um ponto central a ser avaliado é como transcorre o processo discursivo para um possível consenso, explicando a tomada de decisão final.

Importante destacar que, pela teoria de Viehweg, como a lógica a ser adotada é discursiva, utilizando-se de conceitos de diversos sistemas, não há julgamento certou ou errado, mas o legitimado entre as partes, a partir da fundamentação argumentativa, que gera o consenso. Na verdade, há inúmeras decisões possíveis a serem adotadas, ao contrário da ilusão de que um sistema dogmático traria um julgamento correto e conforme com o sistema. Entretanto, o que chama atenção é que a dialética em conflitos envolvendo o direito à cidade ou à moradia de população de baixa renda no Poder Judiciário, normalmente, não chega a resultados que favoreçam este grupo social, ainda que haja o pensamento problemático. Esta é outra avaliação que deve ser realizada no estudo dos casos escolhidos em que atuou o Núcleo de Habitação e Urbanismo da Defensoria Pública.

Será conferido destaque, portanto, no significado dos discursos de cada um dos atores e na sua argumentação, considerando-se que os direitos em disputa estão em constante evolução, não possuindo um sentido previamente fixado. No dizer de Fabiana Pinho (2016, p. 13), esta concepção situacional do discurso e da 
argumentação evidencia a ênfase conferida por Viehweg à pragmática, uma vez que Ihe é relevante entender e avaliar como os signos são utilizados pelos participantes do discurso, considerando o contexto em que este transcorre.

Um questionamento interessante diz respeito a quais os limites para a adoção de topoi argumentativos, assim como para a formulação de acordos. Viehweg (1979, p. 42) afirma que a única instância de controle e discussão é a própria dialética, o que pode parecer muito arriscado. Entretanto, o jusfilósofo esclarece que, se se tem em conta que aqueles que disputam possuem um saber que já passou por uma experimentação e comprovação, os acordos terão aceitação se os argumentos tiverem peso específico.

Para Lênio Streck (2014, p.345), o grande limite discursivo que pode haver para o debate seria a própria Constituição, que deveria ser o topos hermenêutico que conformaria a interpretação do restante do sistema jurídico, por ser um espaço garantidor das relações democráticas entre o Estado e a Sociedade.

Sobre este aspecto, é relevante investigar, nos casos a serem estudados, em que medida a qualidade do disputante é avaliada em sua argumentação ou se tal peso é trazido apenas pela figura da autoridade, ou seja, pela mera representatividade ou poder do agente. É interessante notar que há, de fato, uma relevância maior conferida a determinados atores jurídicos, entretanto, muitas vezes, este fato faz com que se deixe de fazer a dialética proposta por Viehweg para apenas se considerar os argumentos do agente de maior peso, sem fazer a contradita com a arguição contrária.

\subsubsection{Da força do direito à cidade como um topos}

Theodor Viehweg (1979, p. 36) ensina que a tópica é realizada quando, diante de um problema, buscam-se pontos de vista escolhidos arbitrariamente, que devem ser adequados e fecundos para conduzir a bons resultados, ou seja, servindo como elemento orientador do debate, como fio condutor do pensamento. A esta busca de premissas, de topoi, denomina-se tópica de primeiro grau. Em razão da insegurança desta primeira busca, fazem-se catálogos de topoi, gerando um repertório de pontos de vista, algo que o referido autor chama de tópica de segundo grau. Este catálogo é separado em diversos campos argumentativos, como topoi históricos, lógicos, gramaticais, etc. 
A partir desta catalogação, segue-se para o debate e o convencimento, não havendo uma dedução sistemática de topoi, pois o pensamento deixaria de ser sistemático. Isso ocorre porque, mais importante que concluir, é a busca das premissas, pois o modo que se buscam as premissas influi nas conclusões a serem tomadas.

Imaginando-se, novamente, um conflito fundiário em que uma coletividade de ocupantes de um terreno, todos de baixa renda, estejam ameaçados na sua posse, pode-se fazer um exercício clarificador. Há uma aporia posta por questões muitas vezes inconciliáveis, como, por exemplo, o direito à moradia da população pobre em confronto com o direito de propriedade do titular registral do terreno. Os operadores jurídicos partirão para a busca de seus lugares comuns: moradia, cidade, propriedade, liberdade, selecionando quais são adequados ao problema em questão.

Em relação à moradia, por exemplo, pode-se buscar definições que deem concretude ao topos e o articulem discursivamente. Podem ser feitas referências históricas para construir um raciocínio sobre o acesso à moradia, utilizar-se de definições urbanísticas sobre moradia adequada, enfim, utilizar-se de diversos sistemas, que não apenas o jurídico. Formadas as narrativas, tenta-se o consenso, legitimando os argumentos, em uma arte inventiva, que crie uma solução que não está previamente definida no sistema jurídico.

Conforme foi dito acima, a análise do desenvolvimento do discurso pode ilustrar em que medida o direito à cidade é utilizado como topos e como há seu desenvolvimento para solução de problemas, permitindo visualizar por uma outra lógica - mais aproximada como o que se faz na práxis - os motivos de sua eventual não efetividade.

Outro aspecto que pode servir de norte é o trabalhado por Lothar Bornscheuer (1976, apud, PINHO, 2016, p. 20), que entende o tópos não apenas como uma categoria abstrata do discurso que serve para dar início a raciocínios dialéticos e retóricos, mas, principalmente, como um arcabouço moral, político e social, que abriga os valores vigentes e as práticas sociais consolidadas de certa comunidade. Deste modo, para que um lugar comum pudesse ser considerado um topos, deveria dispor de quatro características: habitualidade, potencialidade, intencionalidade e simbolicidade, as quais se definiriam da seguinte forma: 
A característica "habitualidade" (Habitualität) constitutiva do tópos destaca a sua faceta como um padrão de consciência internalizado pela sociedade, que se manifesta no seu hábito linguístico e comportamental.

(...)

O atributo da potencialidade enfatiza a possibilidade de em uma discussão os participantes empregarem o mesmo tópos para a elaboração de argumentos conforme a perspectiva adotada por cada um deles.

(...)

O atributo "intencionalidade" (Intentionalität) como terceira característica estruturante do tópos ressalta que a sua função não é de gerar quaisquer efeitos, mas efeitos precisos em um debate dialético-retórico orientado pelo problema. Assim, esta característica pressupõe as duas acima mencionadas - habitualidade e potencialidade - mas dá um passo além. O tópos não consiste apenas em um padrão consolidado através da tradição e convenções sociais e linguísticas, tampouco em um ponto de vista aplicável a qualquer discussão. A estas duas qualidades do tópos soma-se o fato de que o tópos aponta para um determinado horizonte de compreensão construído pelo modo em que a sociedade pensa e se comporta.

(...)

A característica da "simbolicidade" (Symbolizität) denota a capacidade de o tópos, dependendo daquele que o emprega e da situação em que é empregado, tomar a forma mais apropriada para os usuários de determinado setor da sociedade.

Assim sendo, para que um lugar comum como o direito à cidade pudesse ser avaliado como um topoi, não bastaria sua mera utilização por um debatedor, sendo necessário que ele portasse as características elencadas acima, a ponto de ser dotado de força persuasiva. A avaliação do quanto o direito à cidade é internalizado no padrão de consciência da sociedade, o potencial de sua utilização para a defesa de argumentos, quais os efeitos precisos que ele pode alcançar em um debate e qual o seu poder simbólico podem contribuir para entender a sua baixa ou elevada aplicação na prática argumentativa.

Essas características são um importante referencial para se avaliar as possibilidades do uso do direito à cidade, em um contexto de justiça social, ter significância no campo jurídico. A princípio, percebe-se que a simples articulação deste topos, ainda que por um agente dotado de grande capital simbólico, não é suficiente para sua naturalização nos costumes das pessoas, pois todas indicam uma internalização na sociedade que implica uma verdadeira mudança cultural. 


\section{CAPITULO 04 - A DISPUTA PELO MONOPÓLIO DO DIREITO À CIDADE: UMA LEITURA A PARTIR DE CASOS CONCRETOS ENVOLVENDO A DEFENSORIA PÚBLICA DO ESTADO DE SÃO PAULO}

Para uma avaliação de como ocorre a disputa no campo jurídico em relação ao direito à cidade, será feita a avaliação de 04 casos em que há a concorrência pelo seu monopólio. A teoria de Bourdieu será relevante para que se descortine, em cada caso, qual o interesse de cada agente ou instituição, superando-se os mascaramentos que o discurso jurídico apresenta. Sabe-se que a noção de campo jurídico oferece a oportunidade de entendimento das posições de cada operador no campo, no momento em que confrontam suas noções sobre o direito à cidade, contudo, é necessária uma abordagem em relação à retórica utilizada.

Neste sentido, a tópica jurídica trabalhada por Thoedor Viehweg vem a complementar as análises, ao permitir a compreensão do modo de pensamento de cada ator jurídico, que determina o uso de um tipo específico de discurso, orientado para a finalidade de proteção de seus interesses. A observação do uso dos topoi permitirá também entender as visões de mundo que estão por trás dos discursos, elucidando melhor as relações de poder que envolvem a disputa pelo direito à cidade.

\subsection{CASO 01: REMOÇÕES DE FAMÍLIAS NO PROGRAMA DE DEFESA DOS MANANCIAIS DE ÁGUA DA PREFEITURA MUNICIPAL DE SÃO} PAULO

No ano de 2007, a Prefeitura Municipal de São Paulo e o Governo do Estado de São Paulo lançaram um conjunto de medidas destinadas a recuperar áreas ambientais e de mananciais, o qual denominara "Operação Defesa das Águas". O programa colocava a questão ambiental como centro da agenda governamental, tendo como objetivo inicial recuperar e proteger principalmente áreas de mananciais próximas às represas Billings, Guarapiranga e Cantareira.

Em convênio formulado entre Prefeitura e Governo Estadual, trouxe-se como objetivo central da operação "a elaboração e implementação de um plano de ação 
integrado com vistas à proteção e recuperação de mananciais (...) tendo como ênfase a preservação de seu caráter de produtora de água, bem como impedir o avanço de ocupação irregular nas referidas áreas e à sua recuperação e urbanização quando degradadas" (cláusula primeira).

No mesmo ato, ficou definida, entre as atribuições do Município e Estado, a de "adotar procedimentos para desfazimentos de ocupação e constrição irregulares com a tempestividade necessária" (cláusula terceira, I, e). O convênio não trazia, de forma concreta, qualquer solução habitacional para as famílias a serem desalojadas, apenas dispondo que o Grupo Executivo de Proteção de Mananciais - que gerenciaria estratégias para as áreas afetadas - teria como função propor e coordenar a implementação das políticas habitacionais e de desenvolvimento urbano para a região.

Os efeitos da política adotada sobre os moradores da região foram imediatos, tendo em vista que moradores das comunidades Jardim Gaivota ${ }^{13}$; Parque Taipas (Jardim Harmonia) ${ }^{14}$, Fazendinha (Rua Gervásio Leite Rebelo) ${ }^{15}$, Gerônimo de Abreu Vale $^{16}$ e Rua Rosa Galvão Bueno ${ }^{17}$ buscaram a Defensoria Pública informando que haviam sofrido intervenção da Prefeitura Municipal, com a demolição de suas casas. $\mathrm{Na}$ imprensa informava-se sobre as primeiras remoções de famílias ${ }^{18}$, trazendo-se 0 "Programa de Defesa das Águas" como "polêmico"19, assim como noticiando a busca de algumas famílias pela assessoria jurídica da Defensoria Pública ${ }^{20}$.

O ato administrativo utilizado como fundamento para as remoções era a Ordem Interna $\mathrm{n}^{\circ}$ 01/2007, que trazia entre suas motivações: a) a necessidade de uniformizar o procedimento fiscalizatório das ocupações e dos parcelamentos irregulares e clandestinos implantados no Município de São Paulo; b) preservação das áreas de interesse ambiental, públicas ou privadas, responsabilizar infratores e orientar a

\footnotetext{
13 Procedimento Administrativo NHABURB no 52/2007

14 Procedimento Administrativo NHABURB no $72 / 2007$

15 Procedimento Administrativo NHABURB no 90/2008

16 Procedimento Administrativo NHABURB no $100 / 2008$

17 Procedimento Administrativo NHABURB no $26 / 2007$

18 Prefeitura derruba 14 casas em área de manancial em SP. Agência Estado. São Paulo, 07 jan. 2018.

Disponível em: http://brasil.estadao.com.br/noticias/geral,prefeitura-derruba-14-casas-em-area-damanancial-em-sp,20070417p18247

${ }_{19}$ Defesa das Aguas causa polêmica em SP. Portal G1. São Paulo, 07 jan. 2018. Disponível em: http://g1.globo.com/Noticias/SaoPaulo/0,,MUL58409-5605,00DEFESA+DAS+AGUAS+CAUSA+POLEMICA+EM+SP.html

${ }^{20}$ Defensoria defende moradores desalojados de área de preservação. Consultor Jurídico. São Paulo, 07 jan. 2018. Disponível em: https://www.conjur.com.br/2007-dez05/defensoria defende moradores despejados area ambiental
} 
população. A materialização de um programa de preservação de mananciais desembocava em uma ordem interna, que identificava como o principal vetor de degradação ambiental a ocupação irregular do solo urbano.

O Estado é portador do poder simbólico de unidade social, em que as divisões sociais são superadas pela ideia do "interesse público". Esta noção de interesse geral produz o imaginário de que as autoridades são portadoras de "boas razões", fazendo com que os interessados aceitem a relação dominação/sujeição sem hostilidade (CUNHA, 1984, p. 88). Neste sentido, dois entes estatais constituem uma política pública que visa a recuperar mananciais de água, colocando como problema central a ocupação fundiária irregular nestas localidades.

Os pressupostos comunicacionais da agenda governamental são formados, portanto, pelos conceitos de preservação ambiental; produção de água para a coletividade e contenção de ocupações irregulares. Há, portanto, dois grandes agentes detentores de poder simbólico, especialmente por meio da noção do "interesse público", que constroem um discurso baseado na contrariedade entre habitação irregular - da população pobre ocupante do local - e a preservação do meio ambiente, bem de toda a coletividade.

Por outra via, os moradores buscaram outro organismo estatal, qual seja, a Defensoria Pública, igualmente detentor de um poder simbólico, em que se apresenta como elemento legítimo a representar o interesse geral, porém com uma especificidade maior: o interesse jurídico da população de baixa renda. Este ponto traz uma orientação de discurso da referida Instituição, a qual também foi moldada a partir de sua criação vinculada a atores de luta por cidades democráticas.

Cria-se uma imposição de visualização da questão sob outros pressupostos, em que se coadune a proteção ao meio ambiente com o direito à moradia daquela população. $O$ desafio seria estudar alternativas técnicas que viabilizassem 0 atendimento dos objetivos da Lei de Proteção aos Mananciais sem o altíssimo custo social da remoção da população (MARTINS, 2006. p. 12). Neste sentido, formam-se os elementos discursivos que se iniciam no campo político, por meio de uma intervenção que interfere no espaço urbano e desembocará no campo jurídico, em que se disputará a hegemonia por dizer o direito: conflito entre meio ambiente e direito à moradia, que resultam em uma visão sobre o espaço urbano. 
A execução do referido planejamento de intervenção na área de mananciais foi traduzida juridicamente pela Ordem Interna ㄲo 01/2007 da Prefeitura Municipal de São Paulo - que dispunha o seguinte sobre ocupações em áreas públicas:

1. Havendo invasão de área pública municipal ou área pública cedida ao Município, a qualquer título, a Subprefeitura deverá tomar as seguintes providências, simultâneas ou não, conforme o caso:

(...)

1.5. Após autorização do Subprefeito, retomar o bem público municipal e demolir as obras e edificações nele erigidas, nos seguintes casos:

a) obra ou edificação não habitada, em qualquer estágio de construção;

b) obra ou edificação habitada em ocupação não consolidada;

c) acréscimos irregulares construídos em edificação habitada em ocupação consolidada;

d) obra ou edificação nova, habitada ou não, acrescida em ocupação caracterizada como consolidada anteriormente.

1.9. Em se tratando de ocupação consolidada, destinada à habitação, encaminhar o processo à Secretaria da Habitação, para a verificação da viabilidade da regularização das moradias.

1.10. Tratando-se de parcelamento consolidado e sendo necessário o ajuizamento de ação judicial para a reintegração de posse,

4. (...)

IV - As pessoas que forem prejudicadas em decorrência da má fé de corretores, vendedores de loteamentos clandestinos e irregulares devem ser orientadas para que os denunciem aos órgãos de defesa do consumidor e da polícia civil e possam ser ressarcidas dos seus prejuízos, se for o caso.

Este caso ilustra como a construção de conceitos jurídicos como o direito à cidade, direito ao meio ambiente ou à moradia não possuem, necessariamente, uma definição prévia, sendo construído a partir do manejo da linguagem jurídica. $O$ direito como discurso também mostra como esta concretização não é feita apenas por meio de leis ou da jurisprudência, podendo ser realizada por um mero ato administrativo (Ordem Interna no 01/2007) de um agente, como uma Prefeitura.

$O$ referido ato administrativo colocava como critério de distinção sobre em que casos a Prefeitura poderia exercer o poder de polícia para fiscalizar as ocupações, demolindo construções, a consolidação da ocupação, entretanto, em nenhum dispositivo esclarecia quais características a definiriam. Deste modo, não havia como 
estabelecer quais os casos em que a Prefeitura, de fato, encaminharia para regularização fundiária ou para remoção pela via judicial. O Item 4. IV. da Ordem Interna é revelador ao encaminhar as pessoas prejudicadas à polícia ou órgão de defesa do consumidor, sem alçar a Municipalidade à categoria de responsável por garantir os direitos dos ocupantes de boa-fé.

Assim, a Prefeitura passou a notificar moradores para, em um prazo de 72 horas, contados a partir do recebimento da notificação, "desocupar o local, retirar os pertences, desfazer a construção e recuperar a área em seu estado original'. Percebase que, ao se editar a Ordem Interna e coloca-la em execução, faz-se uma interpretação do que significa o direito à cidade, ao meio ambiente ou à moradia, gerando-se uma repercussão direta sobre a realidade.

Essa criação de uma noção do direito à cidade é erigida mesmo fora do âmbito do Poder Judiciário, sendo disputada pelo corpo técnico de uma secretaria municipal que edita este ato, em contraposição a outros agentes que a combatam. Desta forma, produz-se um direito à cidade que se transforma cotidianamente.

\subsubsection{A Judicialização do conflito entre Prefeitura Municipal e Moradores e o uso dos topoi}

Em que pese a Defensoria Pública ter como atuação prioritária a extrajudicial, normalmente na questão habitacional, as famílias buscam a Instituição quando sofrem real risco de remoção. Isto gera uma urgência que impele a Defensoria a judicializar os casos de forma rápida. Deste modo, o Núcleo de Habitação passou a propor Ações Civis Públicas em face do Município de São Paulo, em defesa das comunidades que buscaram seus serviços, trazendo como argumentos principais os que seguem:

a) o desfazimento de loteamentos, ainda que não consolidados, não podem ser feitos sem ordem judicial;

b) violação à ordem urbanística, pois a remoção retirava dos moradores os benefícios de uma cidade sustentável, negando-lhes os instrumentos de urbanização e regularização fundiária;

c) direito à moradia digna, fundado na obrigação de o Poder Público oferecer políticas públicas de habitação de interesse social; 
d) Poder-dever de o Município promover a regularização dos parcelamentos irregulares, para evitar a lesão aos padrões de desenvolvimento urbano da cidade e na defesa dos direitos dos adquirentes dos lotes;

e) A Lei Municipal 11.775/95, que autoriza a regularização fundiária no Município de São Paulo, traz diversos procedimentos para retornar o lote ao seu estado anterior, que foram violados pela Ordem Interna no 01/07, a qual era ilegal por ultrapassar seu poder regulamentador;

f) Não haveria urgência em demolir casas habitadas, mas apenas em desfazer construções em andamento, impedindo-as. Assim, estaria havendo reintegração de posse sem processo judicial ou situação imediata que a exija.

g) O Poder de polícia da Administração não pode acobertar abusos e violações de direitos.

Estes são alguns dos argumentos de uma petição inicial que demonstra como se desenvolveu o pensamento problemático pelo Núcleo de Habitação. A busca de topoi como ordem urbanística, cidade sustentável, regularização fundiária e moradia, revelam que o problema central para a Defensoria Pública é a permanência das famílias no local. Os referidos topoi vão conduzir a um debate sobre o direito de localização dos moradores dentro de uma cidade que deve ter como função o bemestar das pessoas, as quais têm o direito à moradia digna. Note-se que tais argumentações não são realizadas apenas utilizando-se do sistema normativo, mas também de conceitos urbanísticos ou sociológicos, por exemplo, para se discutir o que seria segregação urbana.

A petição trouxe diversas referências doutrinárias de urbanistas como Raquel Rolnik, juristas no campo urbanístico como Betânia Alfonsin e sociólogos como Silvio Caccia Bava (ex-coordenador do Instituto Pólis), demonstrando que o desenvolvimento do discurso jurídico se vale da construção acadêmica, a qual também molda a formação do campo jurídico.

Outro ponto colocado como destaque pelo Núcleo de Habitação é a discussão sobre o poder de uma administração pública perante direitos de magnitude constitucional. Isto é, estabeleceu-se como o segundo problema a legalidade da Ordem Interna, obrigando o debate sob o viés do direito administrativo. A ação discursiva da Defensoria Pública, portanto, não posiciona o meio ambiente como foco da questão. 
Os pedidos eram pela anulação dos atos administrativos de desfazimento de loteamentos, reparação dos danos, inscrição dos ocupantes dos imóveis demolidos em programas de desenvolvimento urbano, oferecendo imediata disponibilidade de linhas de financiamento público para aquisição de imóveis.

A Procuradoria Geral do Município apresentou defesa na ação civil pública da Comunidade Fazendinha, em que afirmava no mérito que:

a) o pedido era juridicamente impossível, pois visava a resguardar direito exercido irregularmente, praticado mediante ato ilícito;

b) não poderia haver efeitos legítimos para ocupações realizadas ao arrepio da lei, caso contrário haveria beneficiamento destas pessoas, frente a outras pessoas carentes que adquirem imóveis de forma legal, ou seja, ocorreria violação ao princípio da isonomia;

b) Haveria afronta à separação dos poderes, pois o Poder Judiciário invadiria política do Poder Executivo;

A petição, a qual articula o discurso jurídico que traduz a aspiração política municipal, foi sucinta e não buscou dialogar sobre a validade da Ordem Interna ou sobre as questões urbanísticas subjacentes. Os topoi da Procuradoria Municipal são completamente diversos, partindo do pressuposto de que o meio ambiente precisa ser preservado do seu maior violador: a ocupação irregular de terras. Portanto, os topoi elencados são a ilegalidade de ocupações irregulares; lesão à isonomia comparativamente a pessoas que moram em espaços regularizados; autonomia do Poder Executivo em efetivar políticas públicas.

Importante destacar que o Município trabalha seu próprio conceito de direito à cidade, traduzindo-o na afirmação de que apenas tem este direito quem está em conformidade com a legislação de parcelamento do solo urbano, trazendo uma condicionante que transparece que a cidade existente é apenas a regularizada.

O caso é exemplificativo sobre o ensinamento de Theodor Viehweg, de que não há um pensamento sistemático, em que se partem de normas jurídicas, realizando-se deduções até que se chegue a uma solução do caso concreto. Na prática, os juristas analisam o problema e escolhem os pressupostos ou topoi argumentativos que os conduzam a um resultado satisfatório. Assim, a grande disputa que se estabelece é pela consolidação dos topoi mais adequados ao caso, pois os pressupostos assumidos condicionam radicalmente a solução a ser conferida ao conflito. 
Se os topoi a serem assumidos forem referentes ao direito urbanístico, dificilmente se chegaria a algum resultado que deixasse as famílias sem a garantia de direitos mínimos. Por essa razão, a Municipalidade conduza a questão para a esfera do direito ambiental - em que se contrapõe o direito de toda a sociedade em face de poucos moradores - e do direito administrativo - especialmente para a autonomia do Poder Executivo, evitando-se o enfrentamento discursivo.

\subsubsection{As relações de poder no campo jurídico reveladas nas Ações Civis Públicas}

Na litigância realizada pela Defensoria Pública, foram encontradas 05 Ações Civis Públicas nos arquivos do Núcleo de Habitação, as quais tiveram resultados a serem demonstrados abaixo.

1) Processo $n^{\circ}$ 0104600-35.2008.8.26.0053, referente ao Jardim Gaivotas:

Houve sentença proferida por juiz da Vara da Fazenda Pública julgando os pedidos improcedentes, afirmando que "os ocupantes da mencionada área violaram, portanto, a lei e certamente causaram danos ao meio ambiente, na medida em que desmataram o local para a construção de habitações."

Utilizou-se como fundamento da decisão o art. 225 da Constituição Federal, o qual dispõe que cabe ao Poder Público preservar o meio ambiente, bem como $o$ art. 30 , VIII, que estabelece a responsabilidade municipal de promover o adequado ordenamento territorial. O magistrado utiliza o Estatuto da Cidade, citando o art. $2^{\circ}$, $\mathrm{VI}$, alegando que a ordenação e controle do uso do solo servem para evitar a poluição e degradação ambiental, assim como a utilização inadequada de imóveis urbanos. Deste modo, a Ordem Interna ํㅡ 01/07 estaria em conformidade com o Poder de Polícia da Administração Pública, cumprindo os deveres acima. Afirmou, ainda, o julgador que o direito à moradia não é absoluto, devendo se compatibilizar com o direito ao desenvolvimento urbano sustentável e o direito ao meio ambiente ecologicamente equilibrado.

O juiz avaliou que de 98 residências demolidas, 08 famílias se interessaram por um auxílio-locação de $\mathrm{R} \$ 300,00$ mensais, 02 famílias aceitaram passagens para retornar à cidade natal, de forma que o Município havia tomado as providências necessárias para garantir às famílias abrigo com as condições adequadas de uma vida digna, de forma provisória, a fim de que pudessem reorganizar suas vidas. Por 
fim, entendeu que o Município não deveria incluir os ocupantes em programas de desenvolvimento urbano, pois estes já existiam com regras próprias e não caberia indenização às famílias.

A decisão judicial revela que o magistrado se utiliza de diversos conceitos, a exemplo da própria ordem urbanística, por meio da citação de dispositivo do Estatuto da Cidade. Entretanto, a lógica de cidade acolhida é a exposta pelo Município, fundamentando-se na necessidade de controle do solo urbano pelo Ente Municipal, mas com referência à proteção do meio ambiente, que é o pressuposto mais importante para a fundamentação da sentença, contando com citação de dispositivos constitucionais.

Quando a decisão aborda o direito à moradia, não o convoca como dever do Município - a exemplo do que se fez em relação ao parcelamento do solo urbano mas sim o aborda para despojar as famílias de tal direito, ao alegar que este não pode se sobrepor ao direito ao meio ambiente. Portanto, nem mesmo se considera o dever de cadastrar os moradores em lista de programas habitacionais.

Deve-se destacar que não ocorre na sentença o proposto por Theodor Viehweg, não tendo se verificado a contraposição dos topoi por meio de argumentação, em que o magistrado chega a uma síntese, pois o que se nota é que a decisão assume os pressupostos dos juristas da municipalidade, desenvolvendoos. Não há uma tentativa do magistrado de dialogar com diversos os topoi elencados pela Defensoria Pública, especialmente os que se fundam em uma cidade democrática e socialmente referenciada. Assim, percebe-se que houve apenas uma assunção dos pressupostos do Município, o que conduziu a uma sentença em conformidade com seus interesses.

Por fim, a Defensoria Pública apresentou recurso de Apelação, entretanto, obteve êxito apenas em afastar a condenação em pagamentos de ônus sucumbenciais.

2) Processo no 0136439-15.2007.8.26.0053 - Parque Taipas (Jardim Harmonia):

A ação foi influenciada por sentença proferida na Ação Civil Pública no 583.53.1999.403.758-5, que determinou a desocupação do Jardim Harmonia pelos moradores, o que culminou com a desistência do pedido de anulação da Ordem Interna $\mathrm{n}^{\circ}$ 01/07, mantendo-se apenas o pedido de inclusão prioritária dos ocupantes em linhas de financiamento habitacional. Deste modo, o magistrado não foi compelido 
a avaliar a regularidade dos atos da Prefeitura. Analisando o pedido restante, o juiz entendeu que não caberia qualquer prioridade aos moradores na sua inclusão em cadastro de aquisição de imóveis por financiamento público, pois não se tratava de remoções por calamidades públicas. Assim, entendendo que caberia ao Município a inscrição regular das famílias desalojadas nos cadastros, julgou procedente, em parte, o pedido da Defensoria Pública, porém determinando o cumprimento da ordem apenas 90 dias após o trânsito em julgado da ação.

Houve recurso de Apelação interposto pelas duas partes e a 9ạ Câmara de Direito Público do Tribunal de Justiça de São Paulo entendeu que deveria ser mantida a obrigação de realização do cadastro dos moradores, afirmando que a viabilização da política pública de moradia é uma discricionariedade da administração e que tal escolha "somente se reputará inadequada se resultar na ineficácia do direito que o Estado se obriga a resguardar. Em casos tais, o controle de tais atos não será apenas uma faculdade para o Poder Judiciário, mas verdadeiro dever de defesa da ordem jurídica." Continua o Acórdão, assegurando que “incumbe ao Poder Público desenvolver a tarefa de viabilizar o cumprimento da promessa constitucional e assegurar o direito de moradia. Trata-se de norma de eficácia imediata que assegura para todo cidadão o direito à moradia, como dever do Estado, independentemente de edição de qualquer ato normativo inferior para legitimar a observância do direito subjetivo material custodiado".

Em razão destes fundamentos, o Acórdão deu provimento ao recurso da Defensoria Pública para que houvesse a imediata inclusão dos desabrigados em programa de habitação, sem violar a ordem de inscrições existente, e, havendo necessidade de atendimento prioritário, seja a Municipalidade compelida a tomar todas as providências necessárias para viabilizar o direito à moradia.

O caso do Parque Taipas apresentou resultado juridicamente diverso do Jardim Gaivotas, havendo a procedência da ação para a Defensoria Pública. A sentença afirmou não apenas o direito à moradia das famílias, mas superou o entendimento de que o Poder Judiciário não poderia interferir em políticas do Poder Executivo, além de considera-lo como norma de eficácia imediata, ou seja, independente de normas regulamentadoras para ser implementado.

Neste caso, é possível se vislumbrar a vantagem da metodologia adotada no presente estudo, pois, caso fosse adotada uma análise por meio de levantamento de jurisprudência, tal caso seria catalogado como exitoso, por ter sido 
acolhidojudicialmente o direito à moradia. Entretanto, percebe-se que a de sentença apenas foi favorável ao direito de à moradia em razão de o problema central haver sido excluído da apreciação do Judiciário: a permanência dos moradores no local.

$\mathrm{Na}$ verdade, a permanência dos moradores na área de mananciais representa a inviabilização de toda a política pública proposta pelo Município em convênio com o Governo Estadual. Considerando-se a concepção de Bourdieu de que há relações de poder ocultadas pelo discurso simbólico, entende-se que uma decisão judicial desfavorável ao Município significa o conflito entre grandes atores na hierarquia de construção do poder simbólico no campo jurídico, ou seja, o Poder Judiciário em face dos outros dois entes estatais.

No caso do Jardim Gaivotas, entendeu-se que a procedência da Ação Civil Pública representaria uma ingerência do Poder Judiciário no Poder Executivo, que, em um cálculo de pertinência, não é aceito, demonstrando que o interesse maior do julgador não é trazer paz social, mas sim absorver a insegurança jurídica, como se passa a explicar.

O primeiro impulso natural do poder é a autoconservação, de modo que é intuitivo que um Tribunal, em suas relações com outros atores políticos, institucionais ou sociais, procure demarcar e preservar seu espaço de atuação e sua autoridade (BARROSO, 2010, p. 34). Deste modo, é natural que um Tribunal realize uma avaliação de sua decisão ter aplicabilidade ou causar o mínimo possível de atritos com outros atores poderosos.

A quebra da política de mananciais pela manutenção de moradores geraria um grande confronto de entes estatais poderosos, tendo o potencial de interferir nas relações entre os Poderes da República, de trazer foco midiático contrário à atuação do Judiciário ou até mesmo a negativa de cumprimento da decisão, retirando a autoridade da Corte. Neste cálculo, é menos instável negar o direito à moradia para uma população de baixa renda, defendida por uma instituição recente, como a Defensoria Pública.

Esta avaliação estava presente no caso Jardim Gaivotas, porém deixou de existir no caso Parque Taipas, permitindo que o Poder Judiciário trouxesse uma decisão que afirmasse o direito à moradia de modo exemplar. Entretanto, a decisão se mostra meramente retórica, ao ocultar este jogo de poder, pois, após a remoção das famílias, a simples determinação de que o Município incluísse os moradores em cadastros de habitação de interesse social, em nada interferiria na sua vida real. As 
listas não significam o acesso imediato à moradia e, em grande parte das vezes, nem mesmo em longo prazo.

Apesar de os casos terem recebido decisões jurídicas opostas, o resultado prático foi idêntico, pois as famílias foram removidas e não receberam qualquer atendimento habitacional efetivo. Além disso, o caso reforça o entendimento de que a questão central para o acolhimento de um direito à cidade mais democrático pelo Poder Judiciário não é o conhecimento da legislação pelos magistrados ou o seu suposto perfil conservador, mas as relações de poder que envolvem todos os atores que constroem o campo jurídico, que conformam o direito de acordo com suas hierarquias construídas historicamente.

3) Processo no 0104601-20.2008.8.26.0053 - Fazendinha (Rua Gervásio Leite Rebelo):

A questão envolvendo a posse dos moradores era discutida na Ação de Reintegração de Posse no 0025801-33.2005.8.26.0004 e na Ação de Desapropriação no 0608104-89.2008.8.26.0053. O imóvel era particular e a Defensoria ingressou na Ação de Reintegração informando que a área em disputa era objeto de programa de urbanização de favelas. Após expedição de ofício pelo Juízo, a Municipalidade confirmou a afirmação, acrescentando que a área era objeto de desapropriação.

Considerando-se que a ocupação era consolidada, bem como considerando planejamento municipal, o Juízo da Ação de Reintegração de Posse entendeu inviável a reintegração, julgando o processo extinto, sem analisar o mérito.

Por outro lado, na Ação Civil Pública proposta pela Defensoria Pública, alegando a ilegalidade da Ordem Interna oㅡ 01/07, a Prefeitura reformulou este ato e editou a Ordem Interna 03/08, em que passou a definir como ocupação consolidada aquela ocorrida há mais de um ano; previu, em remoção envolvendo imóveis públicos municipais, o encaminhamento das famílias para atendimento na Coordenadoria de Assistência Social da Subprefeitura, para inclusão em atendimentos habitacionais; em caso de imóvel particular ou públicos não municipais estipulou prazo de 15 dias para a família comprovar a regularidade da ocupação ou o tempo superior a um ano.

Ante a alteração do ato e com o andamento da reintegração de posse trazendo maior segurança aos moradores, a União dos Movimentos de Moradia da Grande São Paulo e interior, representada pela Defensoria Pública, o Município de São Paulo, com anuência do Ministério Público, firmaram acordo solicitando a extinção do processo. 
Assim, em 20 de janeiro de 2010, foi prolatada sentença extinguindo o processo, pois não haveria mais necessidade de sua continuidade.

Este caso demonstra que, ainda que não se obtenha êxito nas ações judiciais ou ainda que o poder simbólico da construção jurídica trazida pela Defensoria Pública e seus topoi não tenham força suficiente, é possível ter avanços. Na esfera política, alcançou-se um resultado positivo, de forma que o Município se abriu a remodelar sua política ambiental. Ainda que não tenha alterado seus pressupostos, considerou trazer um tratamento habitacional para as pessoas a serem removidas, reconhecendo seu dever em garantir o direito à moradia.

4) Processo no 0106567-18.2008.8.26.0053 - Gerônimo de Abreu Vale:

O Juízo de primeira instância julgou improcedentes os pedidos da Defensoria Pública, entendendo que o ato administrativo possui executoriedade, podendo ser exercitado sem necessidade de ordem judicial. O magistrado fundamentou sua decisão no fato de que, se a ocupação se dava em área de preservação permanente, - dano ambiental já determinaria a atuação urgente da Administração e a regularização fundiária seria "solução insuficiente do ponto de vista ambiental e cara, do ponto de vista prático". Assim, a Administração deveria realizar as demolições, "com base no poder de polícia administrativa, que não pode ser impedido pelo Judiciário, caracterizando-se nesse caso, invasão da esfera de atribuições administrativas." Afirma, ainda, o juiz que é possível a demolição de obra clandestina feita sem alvará, em desobediência a normas edilícias ou em locais em que não é possível a regularização, caso contrário o dano ambiental se tornaria irreversível.

Em relação ao pedido de inclusão dos moradores em programas habitacionais, afirma o magistrado que o pedido é genérico e que a "a inscrição aos programas de habitação equivale a um contrato, para o que imprescindível a anuência dos interessados", além disso a discricionariedade da administração deve ser preservada, não podendo impor tal prática, assim todos os atos da Prefeitura seriam legais.

A Defensoria Pública apresentou recurso de Apelação e a 4aㅡ Câmara de Direito Público do TJSP manteve a sentença, entendendo como legítima a conduta da Administração, independentemente de ordem judicial, dado seu dever de impedir ocupações irregulares e de zelar pelo meio ambiente. Além disso, o poder de polícia existiria para limitar a liberdade de propriedade individuais, prevalecendo o interesse público sobre o particular. Por fim, foi provido o recurso, em parte, para afastar a condenação da Defensoria em ônus sucumbenciais. 
5) Processo № 0104140-82.2007.8.26.0053 - Rua Rosa Galvão Bueno:

O processo foi julgado improcedente nos juízos de primeira e segunda instância. A Defensoria Pública interpôs Recurso Especial para o Superior Tribunal de Justiça e Recurso Extraordinário para o Supremo Tribunal Federal, tendo ambos sido negados na origem, por falta de requisitos formais. O mesmo ocorreu nos casos das Comunidades Parque Taipas e Gerônimo de Abreu Vale, inviabilizando a discussão de direitos pelos Tribunais Superiores.

A propositura das 05 Ações Civis Públicas tiveram destinos diversificados, entretanto, em nenhum deles, a Defensoria Pública obteve êxito em anular a Ordem Interna ํo 01/07, ainda que o resultado da ação no caso Parque Taipas tenha sido pela procedência da ação. Considerando-se o teor das alterações ocorridas na Ordem Interna $n^{0}$ 03/08, pode-se dizer que a repercussão negativa das remoções na imprensa e a atuação da Defensoria Pública e de eventuais advogados particulares na defesa dos moradores conduziu a Prefeitura a remodelar suas intervenções. Entretanto, não ocorreu uma alteração da política pública de limpeza dos mananciais a partir das remoções de moradores, o que continuou a ocorrer em larga escala nos anos posteriores ${ }^{21}$.

A interrupção de tal política de remoções apenas teve uma inflexão a partir do ano de 2013, com a alteração do comando da Prefeitura Municipal, o que ficou traduzido na edição da Ordem Interna ${ }^{0}$ 01/13, em que a municipalidade estabeleceu critérios para a retirada de moradores em regiões de risco geológico. No referido ato, foi prevista, prioritariamente, atuação para eliminação do risco, privilegiando a manutenção das pessoas nas moradias. Apenas na hipótese de risco elevado, as pessoas seriam retiradas de suas moradias, viabilizando-as a acessar auxílios financeiros diretos ou disponibilidade de vagas em unidades habitacionais, atendidas as exigências legais.

A Defensoria Pública acompanhou a Ordem Interna o 01/1322 arquivando por compreender que não se identifica violação a direitos pelo referido ato, entendendo que seria inviável avaliar, de forma abstrata, eventuais consequências negativas em decorrência da sua existência. Fica claro, portanto, que a solução não veio

\footnotetext{
21 Projetos em execução pelo poder público em São Paulo vão desalojar compulsoriamente de suas casas cerca de 50 mil famílias em dez anos (2006-2015), no maior deslocamento populacional forçado já registrado no Estado. Agora São Paulo. São Paulo, 12 jan. 2018. Disponível em: http://www.agora.uol.com.br/saopaulo/ult10103u819548.shtml

22 Procedimento Administrativo NHABURB no 15/2013
} 
diretamente pela via judicial, tendo esta se revelado apenas como um instrumento de pressão para gerar consequências no campo político. 


\subsection{CASO 02: LEILÕES DE IMÓVEIS NA REGIÃO DAS ÁGUAS ESPRAIADAS PELO GOVERNO DO ESTADO DE SÃO PAULO}

No dia 05 de setembro de 2013, cerca de 20 moradores da área localizada nos bairros dos Brooklin e Campo Belo, em São Paulo, buscaram a Defensoria Pública especificamente o Núcleo de Habitação e Urbanismo - surpreendidos com um documento denominado "comunicado", emitido pela Secretaria de Planejamento do Governo do Estado de São Paulo, o qual foi deixado embaixo de suas portas. $\mathrm{O}$ comunicado continha imagens das fachadas das residências dessas pessoas e se iniciava com o seguinte informe:

O Estado de São Paulo colocou à venda por meio de concorrência pública imóveis, localizados em regiões nobres na Capital, Bairros Brooklin e Campo Belo. Caso tenham interesse nos imóveis, seguem abaixo informações necessárias para participação

Tratava-se da abertura de 10 licitações, por meio de concorrências ${ }^{23}$ do tipo maior oferta, para a venda de 60 imóveis localizados ao longo da Avenida Jornalista Roberto Marinho, em que a alienação não poderia ocorrer por preço inferior ao da avaliação. A primeira concorrência estava agendada para o dia 13 de setembro de 2013, portanto, poucos dias após o recebimento das comunicações pelos moradores.

O incompreensível se afigurava para aquelas pessoas, tendo em vista que residiam naquelas casas havia mais de 20 anos e, repentinamente, tinham suas moradias, construídas com seus esforços de uma vida inteira, colocadas à venda. Além disso, questionava-se qual o interesse do Estado naquelas concorrências públicas, tendo em vista que não tinha havido qualquer publicidade prévia, abertura

${ }^{23}$ Concorrência pública no 003/2013-GS e processo SEP 0657/2008; concorrência pública nํ0 004/2013GS e processo SEP 0635/2008; concorrência pública no 005/2013-GS e processo SEP 0628/2008; concorrência pública no 006/2013-GS e processo SEP 0128/2008; concorrência pública no 007/2013GS e processo SEP 2245/2008; concorrência pública no 008/2013-GS e processo SEP 2132/2008; concorrência pública no 009/2013-GS e processo SEP 2259/2008; concorrência pública no 010/2013GS e processo SEP 0639/2008; concorrência pública no 11/2013-GS e processo SEP 2264/2008; concorrência pública nº 12/2013-GS e processo SEP 2229/2008. 
de participação na tomada de decisão para as vendas ou abertura de defesa aos moradores nos procedimentos administrativos que culminaram com as licitações.

Os imóveis colocados à venda em concorrência pública se localizam às margens da Avenida Jornalista Roberto Marinho. A área em que fica o leito do Córrego Água Espraiada foi objeto de diversas desapropriações de imóveis pelo Governo do Estado, no início da década de 70, com o objetivo de construção de uma avenida que seria parte de um anel viário. A maior parte dos imóveis ficaram em titularidade do Departamento de Estradas de Rodagem do Governo do Estado - DER. Entretanto, as pretendidas obras foram paralisadas em virtude de modificação no traçado do projeto e os imóveis ficaram abandonados (FIX, 2001, p. 37).

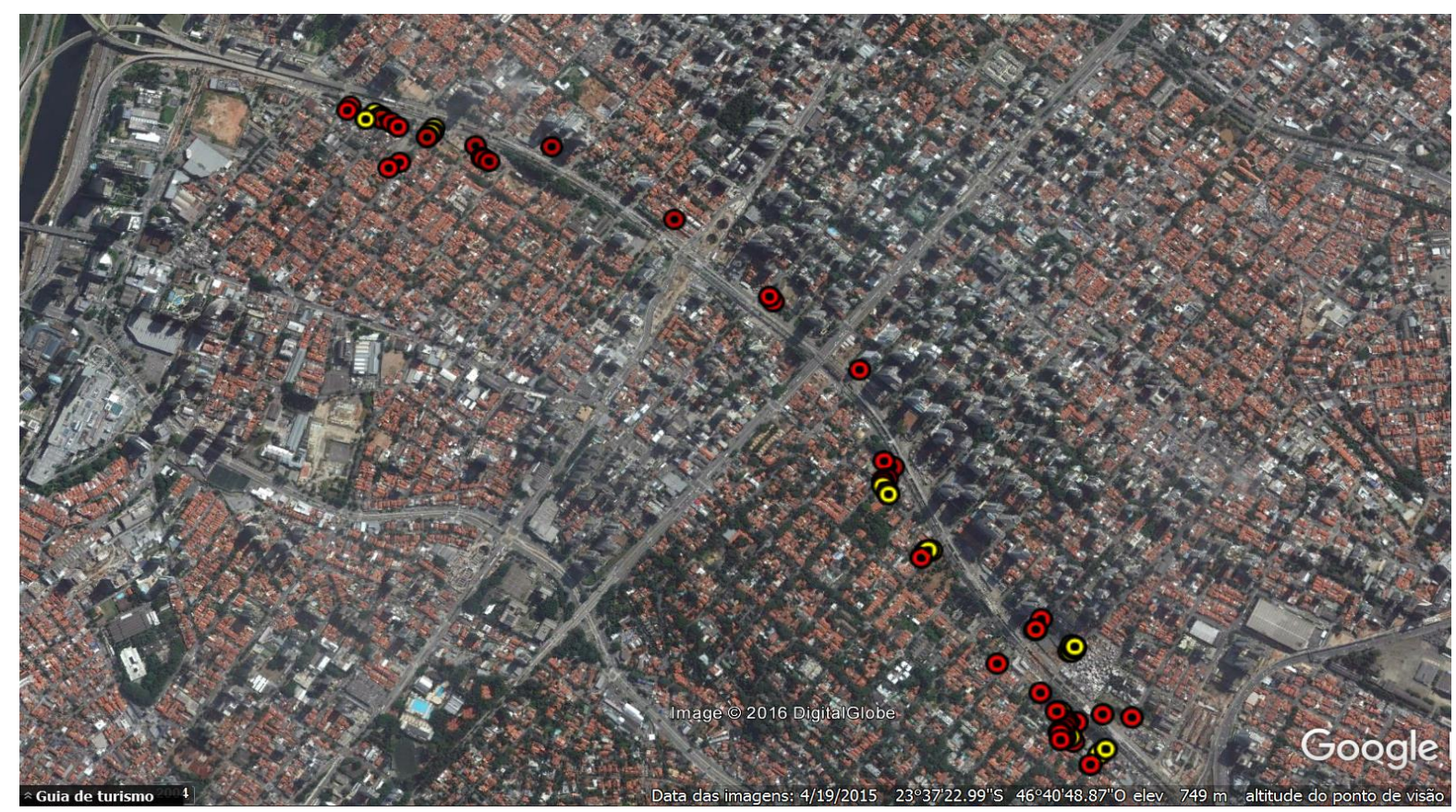

Figura 01, a localização dos 60 imóveis colocados à venda (em amarelo os imóveis retirados das concorrências após intervenção da Defensoria Pública - ver relato abaixo), todos inseridos no perímetro de intervenção da Operação Urbana Consorciada Água Espraiada. Fonte: Google Earth

A área foi ocupada inicialmente por empregados do DER, que passaram a morar no local por meio de autorizações de uso firmadas pelo referido Departamento e, ao longo das décadas seguintes, de forma espontânea, houve ocupação das áreas por pessoas sem qualquer título que justificasse a posse. Os dados da Secretaria 
Municipal de Habitação de São Paulo, pelo sistema HabitaSampa ${ }^{24}$, informam que a ocupação de diversas favelas na região se iniciou nas décadas de 70 e 80, algumas, inclusive, na década de 50.

A região foi alvo de intervenções públicas ao longo das décadas seguintes, porém a Operação Urbana Consorciada Água Espraiada - OUCAE, que aproveitaria o fluxo de capital em direção àquela região, somente seria implantada em 2001, na gestão Marta Suplicy (2001-2004), por meio da Lei Municipal no 13.260/2001.

Em que pesem as inúmeras remoções de favelas ocorridas ao longo de um período de intensa valorização imobiliária, diversas ocupações informais foram se consolidando - aproximadamente 8.500 famílias moradoras de favelas no perímetro da OUCAE, no ano de 2003 (FERREIRA, 2015, p.257) 25_, recebendo infraestrutura como energia elétrica, serviço de água, creches, escolas. Inclusive, segundo o estudo da Arquiteta da Defensoria Pública, Tatiana Zamoner ${ }^{26}$, o terreno localizado na Rua Tibiriçá, 675, que seria afetado pelas vendas, faz parte do Núcleo Urbano ${ }^{27}$ Vila Rica, indicando o recebimento de infraestrutura urbana. Para tais ocupantes, que se consolidaram na região durante décadas, portanto, não fazia qualquer sentido, portanto, o "comunicado" que tinha recebido da Secretaria de Planejamento do Governo do Estado, em outras palavras, ainda era obscuro qual o real interesse naquelas vendas.

\subsubsection{A formação dos topoi para a disputa judicial inicial}

A solicitação de cerca de 20 moradores de alguns dos imóveis atingidos pelas concorrências públicas exigiu uma intervenção imediata da Defensoria Pública, tendo em vista que, em apenas sete dias, os primeiros terrenos seriam vendidos. Deste modo, a Instituição fez uma vistoria técnica em alguns dos imóveis, por meio de sua

\footnotetext{
${ }^{24}$ Como exemplo citam-se as seguintes favelas: Piolho (Sônia Ribeiro), com 400 imóveis, instalada desde 1956; Tibiriçá, com 72 imóveis e ocupada desde 1950; Bernardino de Campos, com 70 imóveis e instalada desde 1970; Volta Redonda, com 66 imóveis e ocupada desde 1976; Niágara, com 35 imóveis e ocupada desde 1980. São Paulo, 28 nov. 2016. Disponível em: http://antigo.habisp.inf.br/aspnet/aspx/espacohabitado/favelalista.aspx.

${ }^{25}$ Conforme relato de Paulo Emílio Ferreira, referenciando-se ao Observatório de Remoções.

26 Informação contida em relatório técnico elaborado para subsidiar a atuação da Defensoria Pública.

${ }^{27}$ Núcleos Urbanizados são favelas que já possuem infraestrutura de água, esgoto, iluminação pública, drenagem e coleta de lixo. São Paulo, 28 nov. 2016. Disponível em: http://dados.prefeitura.sp.gov.br/dataset/nucleo-urbanizado-da-cidade-de-sao-paulo .
} 
arquiteta, constatando-se que alguns núcleos de baixa renda seriam atingidos pelas concorrências.

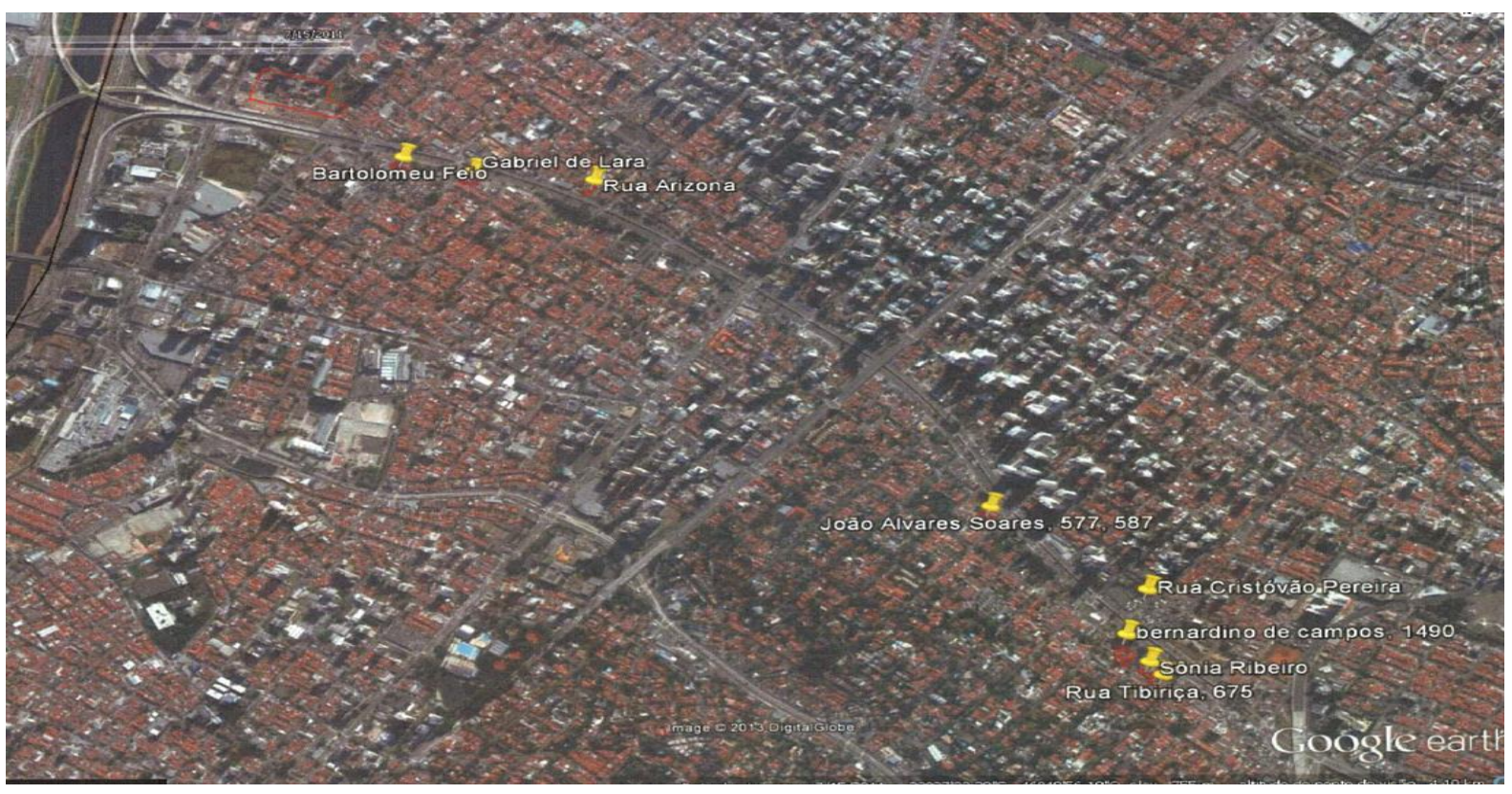

Figura 02 - Imóveis vistoriados pela Defensoria Pública e que eram objeto de venda pelo Governo do Estado. Em todos foram encontradas precariedades ou adensamento típico de favela. Fonte: Google Earth

No relatório demonstra-se, por exemplo, que, na Rua Bartolomeu Feio, as antigas residências unifamiliares tinham sido subdivididas, as antigas garagens foram transformadas em moradias e os espaços internos, antes ocupados por áreas de serviço e quintais, deram lugar a famílias que dividem o mesmo lote. Na Rua Gabriel de Lara, números 632 e 638, havia adensamento típico de favela, com acessos internos por corredores e vielas, moradias com espaços reduzidos e acabamentos precários, coabitados por famílias que dividem o mesmo corredor de acesso, sem saída para a via pública, identificando-se cerca de 94 moradores.

O caso se apresentou, portanto, como uma questão de risco de remoção de pessoas de baixa renda, em decorrência de atos administrativos. O pressuposto mais abrangente seria o direito daquelas famílias de usufruírem da cidade, em uma de suas regiões mais valorizadas, ou seja, o formato como os problemas chegam à Defensoria Pública faz com que esta trate o direito à cidade judicialmente como direito de não remoção/direito de localização. 
A Defensoria Pública ingressou com a Ação Civil Pública nํㅜ 003553914.2013.8.26.0053, que tramitou perante a 6 ( $^{\text {a }}$ Vara da Fazenda Pública da Capital do Estado de São Paulo. Na ação, foi deduzido pedido antecipado para suspender todas as licitações de concorrência e pedido final pela sua anulação, fundamentando-se que todos os moradores de baixa renda afetados tinham tempo de posse apto a ensejar Concessão de Uso Especial para Fins de Moradia ${ }^{28}$ - CUEM -, pois estes seriam os verdadeiros titulares dos terrenos, ainda que não reconhecidos. Os procedimentos administrativos que buscavam a venda dos imóveis, portanto, seriam nulos, na medida em que não notificaram os moradores sobre atos que restringiriam direitos fundamentais (moradia), negando-Ihes o direito de exercer o contraditório e a ampla defesa, para arguirem sua titularidade sobre os imóveis.

Seria possível a utilização do direito à cidade como um dos topoi na ação em referência, entretanto a opção da Defensoria Pública foi a de centrar o debate na nulidade dos atos administrativos, em razão da não participação de pessoas que moravam no local havia décadas no procedimento que culminaria na venda dos imóveis. Nem mesmo o pedido de reconhecimento da CUEM foi realizado, pois chegou à conclusão de que a ação teria maior aceitação no Poder Judiciário e, portanto, maiores chances de êxito, se fossem discutidos apenas pertencentes ao âmbito do direito administrativo, como a nulidade do procedimento administrativo. A estratégia teve resultado positivo, pois, em decisão antecipatória de tutela, o Juízo da 6 ${ }^{\text {a }}$ Vara da Fazenda Pública determinou a suspensão de todas as concorrências públicas.

O pensamento da Defensoria Pública foi pragmático, deixando de utilizar concepções urbanísticas como argumentos centrais, recebendo estes apenas destaque secundário. Em primeira análise pode-se imaginar que tal escolha se deu em razão da percepção de que o Poder Judiciário seria fechado ao discurso relativo ao direito à cidade, sendo muito mais complicado explicar e convencer o magistrado sobre a necessidade de predominância do direito de localização a partir de um direito de uso da cidade. Porém, para uma análise mais profunda, é importante resgatar as

28 Possui previsão Constitucional (art. 183, $\$ 1^{\circ}$, CF) e é regulamentado pela Medida Provisória 2.200/2001, conferindo-se direito subjetivo à concessão de uso para fins de moradia à pessoa que possui como seu, por cinco anos, ininterruptamente e sem oposição, até $250 \mathrm{~m}^{2}$ de imóvel público situado em área urbana, utilizando-o para sua moradia ou de sua família. 
características utilizadas por Lothar Bornscheur para definir um topos (habitualidade, potencialidade, intencionalidade e simbolicidade).

Comparativamente a conceitos do direito administrativo ou direito civil, os conceitos do direito urbanísticos são ainda recentes não apenas na sociedade, mas também no meio jurídico, o que dificulta a existência da habitualidade em seu uso, isto é, o hábito linguístico e comportamental de associar os problemas vivenciados no cotidiano com a cidade e à formação do espaço urbano. No momento em que surge uma remoção de família oriundas de licitações feitas pelo Estado, a associação problemática natural dos juristas é de buscar topoi argumentativos como posse/ propriedade ou ato administrativo válido/nulo/anulável. Isso dificulta a concretização do requisito da potencialidade, pois haveria menores chances de, em uma ação comunicativa de todos os envolvidos, estes assumirem o topos do direito à cidade.

Em decorrência da fragilidade das características anteriores, o enfoque do debate sob o direito urbanístico diminuiria a possibilidade de êxito na demada e de se gerar efeitos concretos positivos específicos para as famílias envolvidas, afetando a intencionalidade. Assim, poder-se-ia afirmar que o direito à cidade careceria de maior simbolicidade, pois não ganharia uma forma palpável para seus usuários.

A estratégia adotada pela Defensoria Pública conduz à reflexão sobre a força do direito à cidade como topos, por outro lado, a análise de cada uma das características induz à percepção de que o problema central da Jurisprudência em relação ao direito à cidade não é "a cabeça dos juízes", mas a cultura de toda a sociedade. Discutiu-se, nos capítulos anteriores, como o Direito não é uma estrutura totalmente autônoma, pois, como um campo jurídico, ele pode produzir a realidade, mas também é por ela produzido .

É o habitus social que traz todas as condicionantes de ação e de pensamento, fazendo com que as estruturas sejam reproduzidas. Portanto, não seria um simples ato de vontade de um magistrado ou de vários deles, que trariam o eixo discursivo da questão em estudo ir para o direito urbanístico e seu conceito maior - o direito à cidade. Há uma estrutura de poder simbólico formada que reforçam o direito de propriedade ou o Poder Estatal para intervir no âmbito urbano conforme seu planejamento, que excluem análises sobre a cidade e seu usufruto por todos.

Perceba-se que, em uma lógica dogmática, em que a avaliação dos pontos de partida seria neutra e imparcial, seria extremamente produtivo argumentar como pessoas que residem em um local há mais de 20 anos, possuem o direito de usufruir 
daquele espaço da cidade, além de terem tempo de posse a ensejar uma o seu direito à concessão de uso especial para fins de moradia. Contudo, toda a estrutura estabelecida do campo jurídico fez com que a Defensoria Pública optasse pela utilização de outros topoi argumentativos para enfrentar o problema central, que é a permanência das famílias no local.

Neste sentido, tenta-se ampliar as avaliações que concluem que a pouca recepção, por parte do Poder Judiciário, com relação a direitos, como o direito à moradia ou à cidade, seria questão de simples reacionarismo, para apresenta-la como uma questão de formatação de estruturas sociais. A composição de forças nessa estrutura é agravada, no Brasil, por uma extrema desigualdade social e de participação política, que é reproduzida por todos, inclusive por uma Defensoria Pública que deixa de utilizar tais argumentos como principal força de sua causa.

\subsubsection{Influências políticas sobre o Poder Judiciário e o topos do desenvolvimento econômico}

No caso em estudo, após decisão da juíza de primeira instância suspendendo os leilões, houve recurso pela Procuradoria Geral do Estado de São Paulo - instituição vinculada diretamente ao Governador do Estado e responsável pela advocacia do Estado. Entretanto, a decisão foi confirmação na segunda instância.

Diante disso, a Procuradoria Geral do Estado utilizou-se da chamada "suspensão de segurança" para reverter os efeitos da decisão. O referido instrumento não é um recurso, não é previsto no Código de Processo Civil, sendo um incidente processual de contracautela (CUNHA, 2010, p. 552-555), que não visa a discutir o mérito de uma decisão, mas sim a retirar sua eficácia, a suspender seus efeitos. Segundo este entendimento, a suspensão de segurança proposta pela PGE não pretenderia discutir o acerto dos julgamentos que suspenderam a venda dos imóveis, mas apenas retirar sua eficácia, em outras palavras, acabar com a suspensão, o que significaria, na prática, mudar o conteúdo da própria decisão.

A suspensão de segurança é prevista na Lei oㅡ 8.437/1992 e concede ao Poder Público a prerrogativa de solicitar ao Presidente do Tribunal de Justiça a suspensão de execução de liminar que tenha contra si, em caso de manifesto interesse público ou de flagrante ilegalidade, e para evitar grave lesão à ordem, à saúde, à segurança e à economia públicas". Em outras palavras, não basta a discussão de um processo 
- o qual é expressão de um estado democrático de direito - decidido em duplo grau de jurisdição, pois, caso o Poder Público perca no mérito, terá uma "chave" de acesso direto ao Presidente do Tribunal de Justiça para discutir a pertinência política daquela decisão, de acordo com critérios vagos como interesse público ou economia pública.

Deste modo, o Governo do Estado de São Paulo apresentou sua Suspensão de Segurança № 2065824-18.2013.8.26.0000, alegando que o impedimento à realização dos leilões teria: a) ferido a ordem pública, dificultando o exercício da administração por autoridades eleitas pelo povo; b) lesado a economia pública, tendo em vista o risco de não obtenção de recursos vultosos, necessários à integralização do capital social da Companhia Paulista de Parcerias - CPP 29 , a qual teria projetos que ultrapassam $R \$ 51$ bilhões, de forma que a receita da venda dos imóveis concretizaria obras como 06 linhas novas de metrô; construção de fóruns judiciais; expansão do sistema prisional; construção de 20 mil unidades habitacionais; duplicação de rodovias e programas de tratamento de esgoto.

Finalmente, após alguns meses de disputa judicial, a finalidade do Governo do Estado com as vendas dos imóveis estava demonstrada: capitalizar uma empresa gerenciadora e garantidora de contratos em parcerias público-privadas. Nesta peça processual surgiu, portanto, o principal topos do Governo Estadual: o interesse público, porém sob a óptica do interesse no desenvolvimento econômico.

À semelhança do caso das Ordens Internas, novamente, cria-se a oposição entre um interesse público que seria de toda a população - o desenvolvimento econômico - em contraposição ao direito de moradia ou permanência das famílias defendidas. Sendo o peticionante o Governo do Estado de São Paulo - legitimado como defensor do interesse geral - informando sua pretensão em executar obras bilionárias, a probabilidade de êxito torna-se significativa.

O que há de peculiar no caso, contudo, é que a discussão deixa de ser jurídica, passando a ser política. Não se discute mais qual a relevância das moradias, os direitos das famílias ou a legalidade das licitações, mas sim a impossibilidade de projetos de magnitude bilionária serem paralisados por uma discussão sobre direitos. Assim sendo, em 13 de dezembro de 2013, o então Presidente do Tribunal de Justiça,

${ }^{29}$ A CPP é uma sociedade por ações de capital fechado, controlada pelo Estado de São Paulo, criada pela Lei Estadual no 11.688/2004. Na verdade, é uma espécie fundo garantidor para os contratos a serem elaborados com o setor privado. 
Ivan Sartori, permitiu a venda dos imóveis, pois haveria risco para o programa de parcerias público-privadas do Estado de São Paulo.

Em 24 de janeiro de 2014, a Secretaria de Planejamento Urbano do Estado de São Paulo publicou novos 10 editais de concorrências públicas, desta vez para a venda de 42 imóveis, retirando 18 que afirmava que seriam para "residência multifamiliar". Em verdade, quase todos os imóveis apontados pela Defensoria Pública como de população de baixa renda foram retirados dos leilões (imóveis na Rua Gabriel de Lara, Rua Bartolomeu Feio, Rua Bernardino Campos e Rua Tibiriçá), outros apontados, como o da Rua Arizona ou da Rua Sônia Ribeiro, foram colocados em concorrência pública, porém não tiveram licitantes. Ao fim, 25 imóveis dos 42 colocados à venda tiveram a licitação frustrada ou por suspensão ou pela ausência de participantes ${ }^{30}$, por motivos não investigados para os fins do presente estudo.

\subsubsection{A atuação da Defensoria Pública e seus efeitos}

No mês de outubro de 2014 foi prolatada sentença na Ação Civil Pública, com procedência para o pedido da Defensoria Pública, em que o Juízo fundamentou "que os moradores locais preenchem todos os requisitos previstos na MP 2220/01, já julgada constitucional pelo TJSP, na Arguição de Inconstitucionalidade $n^{\circ} 0041454$ 43.2013.8.26.0000, e, portanto, a eles deve ser assegurada a permanência na área", julgando pela anulação de todas as licitações e os procedimentos administrativos que Ihes deram base.

O pedido da Defensoria Pública se restringia à anulação das concorrências, sendo que a Concessão de Uso era apenas parte da argumentação para estabelecer a nulidade em não permitir o direito de manifestação dos moradores nos processos administrativos. A estratégia da Defensoria previa uma atuação célere para garantir os moradores na área, colocar um pedido de declaração de Concessão de Uso traria uma complexidade enorme de produção de provas ao processo (exigindo a comprovação de todos os requisitos da MP 2.220/01 para cada um dos moradores).

Note-se que não é uma praxe dos magistrados o reconhecimento da CUEM ante imóveis públicos, porém o Tribunal de Justiça de São Paulo, por meio de seu

${ }^{30}$ Fonte: Secretaria de Planejamento e Gestão do Governo do Estado de São Paulo. São Paulo, 29. Nov. 2016. Disponível em: <http://www.planejamento.sp.gov.br/index.php?id=26\&pc=rs> e $<$ http://www.planejamento.sp.gov.br/index.php?id=26\&pc=rs\&pagina $=2>$. 
órgão máximo de julgamento - o Órgão Especial - reconheceu a constitucionalidade da CUEM (conforme exposto no trecho da sentença acima) frente à Constituição Estadual. Este tipo de contrariedade demonstra que, em análises de normas em abstrato - como uma arguição de inconstitucionalidade -, pode ser mais fácil para os julgadores a articulação de novos paradigmas jurídicos. Ainda que existam, nestes tipos de julgamento, grandes interesses em jogo e operadores jurídicos utilizando-se de seu poder simbólico em seu discurso, os impactos da decisão não surgem de forma tão direta e imediata como na análise de um caso concreto.

A observação de casos permite demonstrar como os padrões se repetem, ou seja, consagram-se direitos como o de moradia ou CUEM quando a repercussão jurídica é baixa. Reconhecer a constitucionalidade da CUEM é importante passo na construção jurídica, mas não traz a consequência automática de o Estado ter que reconhecer concessões de uso especial para moradia de milhares de pessoas que residem há décadas em áreas públicas, como no caso em questão.

Reafirma-se que, se o pensamento jurídico é problemático, para o Judiciário o problema central é absorver insegurança, o que significa não interferir no status quo dominante, o que traria grandes repercussões, inclusive para o próprio Tribunal de Justiça.

Portanto, após ser retirado de questão a realização das novas concorrências públicas - que foram autorizadas pela Presidência do Tribunal - sem que se tivesse que analisar o direito de CUEM aos moradores, os impactos de uma sentença de procedência aos moradores causam pouco ou nenhum distúrbio na ordem estabelecida. Na prática, as concorrências puderam ser realizadas, não se impediu o projeto de desenvolvimento econômico do Estado e ainda foi possível manter as pessoas no local. Absorveu-se insegurança para ambos os lados, mas não se alterou qualquer estrutura econômica estabelecida, tal qual a visão da cidade como palco de investimentos, nem mesmo se reconheceu a posse dos moradores como originária de CUEM.

A atuação da Defensoria Pública, ao fim, trouxe segurança na posse dos moradores, não pela via judicial, mas pelos efeitos políticos advindos da suspensão inicial das vendas. Primeiramente, fez o Governo do Estado recuar na venda de 18 imóveis em que percebeu que haveria adensamento populacional de baixa renda, além disso, mais da metade das licitações não obteve êxito. 
A Defensoria Pública passou a encaminhar os moradores para solicitar ao Governo do Estado o reconhecimento administrativo da CUEM, entretanto os moradores tiveram seus pedidos negados. A partir de então, os moradores passaram a decidir individualmente se desejariam ingressar com ações judiciais para tentar obter o reconhecimento do seu direito à concessão, o que poderia resolver sua questão habitacional, caso procedente a ação, ou jogar-Ihes na completa vulnerabilidade, se improcedente.

Por fim, outro benefício da atuação da Defensoria Pública foi a descoberta, nas vistorias, das precariedades dos imóveis, muitos com fachadas de casa unifamiliar, porém com adensamento de favela na parte interna, o que tornava a precariedade "invisível". Nem mesmo o sistema HABISP da Prefeitura de São Paulo tinha cadastrado como favelas os imóveis da Ria Gabriel Lara, Bartolomeu Feio e Niágara, o que foi feito após pedido da Defensoria Pública, juntamente com pedido de sua inclusão como Zona Especial de Interesse Social - ZEIS - na revisão do zoneamento do município. Atualmente, no portal GeoSampa, apenas a favela Niágara consta como ZEIS 1.

\subsubsection{Da ausência de uma visão urbanística e da disputa em torno do topos do "interesse público"}

O Governo do Estado de São Paulo, na sua intenção de vender 60 imóveis, apresentou como argumento principal - na suspensão de segurança - o topos do interesse público articulado como a capitalização de uma sociedade garantidora de contratos em parceria público-privada. A percepção do interesse público trazida nas ações judiciais pela Procuradoria Geral do Estado confunde-se inteiramente com o interesse econômico, tendo em vista que analisa apenas a necessidade de arrecadação de dinheiro para alavancar a "fórmula mágica" das parcerias (FIX, 2001), permitindo a realização de obras.

Castells e Borja (1997, p. 156) apontam que nas transformações urbanas recentes se encontram fatores como a sensação de crise aguda, negociação entre atores urbanos públicos e privados e vontade conjunta para que a cidade dê um salto adiante. As manifestações da Procuradoria Geral do Estado trazem este entendimento quando alegam a ausência de recursos do Estado e que a necessidade de capitalização da Companhia Paulista de Parcerias, - CPP é a única solução para o 
desenvolvimento do Estado, em parceria com o setor privado. O topos articulado é o desenvolvimento, sendo a cidade um espaço de negócios que geraria ganhos financeiros para todos, resultando em desenvolvimento social. Se há algum entendimento da cidade como espaço de uso para a sociedade, seu promovedor não é o Estado, por intervenções sociais diretas, mas uma decorrência do avanço econômico e de infraestrutura.

Um ponto relevante ainda não relatado é que nos editais das licitações, no anexo 2 é colocada a descrição dos imóveis e, no item 04 diz o seguinte:

O imóvel encontra-se ocupado e serão de responsabilidade do comprador todas as providências e despesas necessárias para regularizar esta situação, especificadamente quanto à desocupação, não cabendo ao Estado qualquer responsabilidade ou qualquer diligência a esta pendência.

A estratégia do Governo do Estado assemelha-se à atividade de um ente privado, pois diante de um passivo patrimonial, tenta-se a venda para arrecadação de dinheiro para outras atividades, transferindo-se reponsabilidade para o adquirente, como se não existisse qualquer obrigação constitucional ou legal de tal agente público com direitos sociais ou regularização de seus próprios terrenos, que ficaram abandonados por décadas. A noção de interesse público, portanto, é meramente economicista e associado a interesses empresariais privados.

Percebe-se pelas ações judiciais e pelas notícias da época ${ }^{31}$, que a tomada de decisão do governo para a abertura das licitações baseou-se em duas perspectivas: 1) existência de grande passivo imobiliário em região valorizada do município de São Paulo; 2) necessidade de arrecadação ante a crise fiscal pós 2013 para alavancar obras. Não havia qualquer estudo prévio sobre qual era a situação atual dos imóveis adquiridos na década de 70 pelo DER, não existia qualquer noção urbanística acerca dos impactos da venda de mais de 60 imóveis ou debate com população eventualmente atingida, pois tudo seria solucionado apenas com a cláusula que transferiria todos os problemas para o adquirente privado.

\footnotetext{
${ }^{31}$ Notícia da coluna "Poder" da Folha de São Paulo, de 20/04/2016, informa que "O governador de São Paulo, Geraldo Alckmin (PSDB), pediu autorização da Assembleia Legislativa para vender 79 imóveis pertencentes ao Estado para fazer caixa e equilibrar as contas do governo. Os imóveis foram avaliados em R\$ 1,43 bilhão." Folha de São Paulo. São Paulo, 29 nov. 2016. Disponível em: http://www1.folha.uol.com.br/poder/2016/04/1763146-alckmin-quer-vender-79-imoveis-do-estado-desp-para-equilibrar-contas.shtml .
} 
A ausência completa de planejamento é aprofundada quando se descobre que não havia debate da Secretaria de Planejamento do Estado com a Secretaria de Desenvolvimento Urbano ou com a SP Urbanismo, a qual é responsável pela Operação Água Espraiada. Apenas após o enfrentamento de todos os obstáculos judiciais e ante a venda de apenas 17 imóveis dos 60, que se buscou algum diálogo com estes entes por meio da oferta de doação dos terrenos. Esta última ação demonstra, novamente, um interesse do Governo do Estado de se desvencilhar de suas obrigações constitucionais de garantir moradia e combater as causas da pobreza e marginalização, nos termos do art. 23, da Constituição Federal.

Em suma, no caso estudado percebeu-se uma grande tentativa do Governo Estadual de ativar suas parcerias com o setor privado, porém, sem envolver qualquer diretriz de um suposto planejamento estratégico, apenas uma tentativa de arrecadar dinheiro, confundindo a noção de interesse público com o interesse econômico voltado para grandes obras, a despeito de qualquer compromisso social. Este ponto de partida assumido é o que molda a retórica adotada para a disputa no campo jurídico, utilizando-se de topoi como interesse público, crise fiscal, desenvolvimento econômico, para formatar seu discurso, que tem relação com o debate sobre as cidades.

A percepção trabalhada pela Defensoria Pública permitiu outro enfoque sobre o interesse público, direcionado a moradores de baixa renda. $O$ debate gerado na Ação Civil pública tinha como topoi conceitos de direito administrativo, avaliando a validade de licitações, onde se obteve êxito com a procedência do pedido. Entretanto, na Suspensão de Segurança, o Governo do Estado trouxe o debate para a lógica do interesse público pelo desenvolvimento econômico, nos termos acima relatados. Este discurso seria incompatível com a noção de interesse público trazida pela Defensoria Pública, que se relaciona com moradia e direito à cidade como espaço de uso a ser usufruído por toda a população indistintamente, garantindo a permanência no local.

Pela lógica de Theodor Viehweg, ambas as partes partiriam para um debate em que encontrariam um consenso argumentativo, cabendo ao Poder Judiciário estabelecer quando se chegaria nesta síntese. Entretanto, instrumentos como uma suspensão de segurança trazem um poder incomparável para o Estado como operador jurídico, gerando uma maior desigualdade, que lhe garante a possibilidade de impor sua visão jurídica. 
Chama atenção, por outro lado, a permeabilidade do Poder Judiciário para o debate político, desviando-se de suas funções constitucionais, garantindo a venda de imóveis em favor de uma atuação Estatal totalmente desarticulada. $\mathrm{O}$ argumento de um grande prejuízo econômico pelo Governo do Estado, foi suficiente para a interferência da Presidência do Tribunal de Justiça na autoridade de uma decisão avaliada em duplo grau de jurisdição. Segundo a Procuradoria Geral do Estado, a suposta lesão ao erário público afetaria obras estimadas em $\mathrm{R} \$ 51$ bilhões pela Companhia Paulista de Parcerias - CPP, entretanto, a própria Secretaria de Planejamento estimava que se todos os 60 imóveis fossem vendidos, arrecadariam cerca de $\mathrm{R} \$ 29$ milhões, ou seja, nem mesmo $0,05 \%$ do valor total a ser capitalizado. A decisão do Tribunal de Justiça, portanto, antes de representar uma avaliação sobre direitos (p.ex. propriedade dos imóveis pelo Estado $x$ direito à moradia), buscou a imposição da imperatividade do Poder Estatal, concebida pelo "interesse público", especificamente, o interesse econômico desinteressado em qualquer construção social inclusiva.

A intervenção da Defensoria, no caso, não teve o poder de forçar uma atuação planejada ou articulada do estado no espaço urbano, entretanto, reverberou a visão jurídica de uma população que pouco tem suas concepções traduzidas no campo jurídico, constrangendo os Poderes Executivo e Judiciário a se confrontar com a obrigação de preservação de direitos mínimos, resultando na sua não remoção.

Gilberto Bercovici (2009, p. 732), em artigo que avalia o histórico da construção do Estado Social no Brasil demonstra que o projeto nacional não é feito a partir da Constituição, mas apesar da Constituição. Quer-se dizer com isto que são formadas as bases constitucionais do Estado por meio de uma Carta Magna, porém as grandes transformações vão sendo implementadas por outros instrumentos como leis casuísticas, enquanto a Constituição fica esquecida, sem implementação. Ou seja, há diversos direitos garantidos na ordem constitucional, mas basta criar uma legislação sobre uma operação urbana consorciada ou um decreto autorizando venda de imóveis, com cláusula de transferência de reponsabilidade social para os adquirentes dos terrenos, que se realiza a transformação de todo o espaço social e urbano.

Neste panorama, o único papel que resta para a Constituição é o de bloqueio ou resistência, nem sempre bem-sucedido (BERCOVICI, 2009, p. 737). A atuação da Defensoria Pública demonstra esta dinâmica, pois na prática, não se conseguiu a garantia formal do direito à moradia das pessoas por meio da CUEM, mas apenas o 
impedimento da venda de seus imóveis, representando uma sobrevida para os moradores se articularem na defesa de seus interesses. Não seria uma perspectiva pessimista especular que o mesmo Poder Judiciário que, em fundamentação na sentença da Ação Civil Pública, reconheceu o direito dos moradores à CUEM, em futuras ações individuais declaratórias deste direito neguem o pedido, tendo em vista a maior facilidade em ver direitos reconhecidos quando abordados no papel de resistência, do que na efetivação de direitos. 


\subsection{CASO 03: O DIREITO À MORADIA EM FACE DA DEFESA DO MEIO AMBIENTE PELO MINISTÉRIO PÚBLICO ESTADUAL EM POÁ-SP}

No ano de 2006, o Instituto Geológico do Governo de São Paulo realizou um relatório técnico para a Prefeitura Municipal de Poá-SP, mapeando todas as áreas de risco associadas a escorregamentos e inundações daquele município. O laudo afirmava que o objetivo seria subsidiar ações preventivas, emergenciais e mitigadoras de desastres, evitando a perda de vidas, fornecendo subsídios para a Defesa Civil. 0 resultado do estudo foi a identificação de 19 áreas-alvo, com riscos em graus diferenciados, apresentando 1539 moradias sujeitas a algum tipo de risco de desastre geológico.

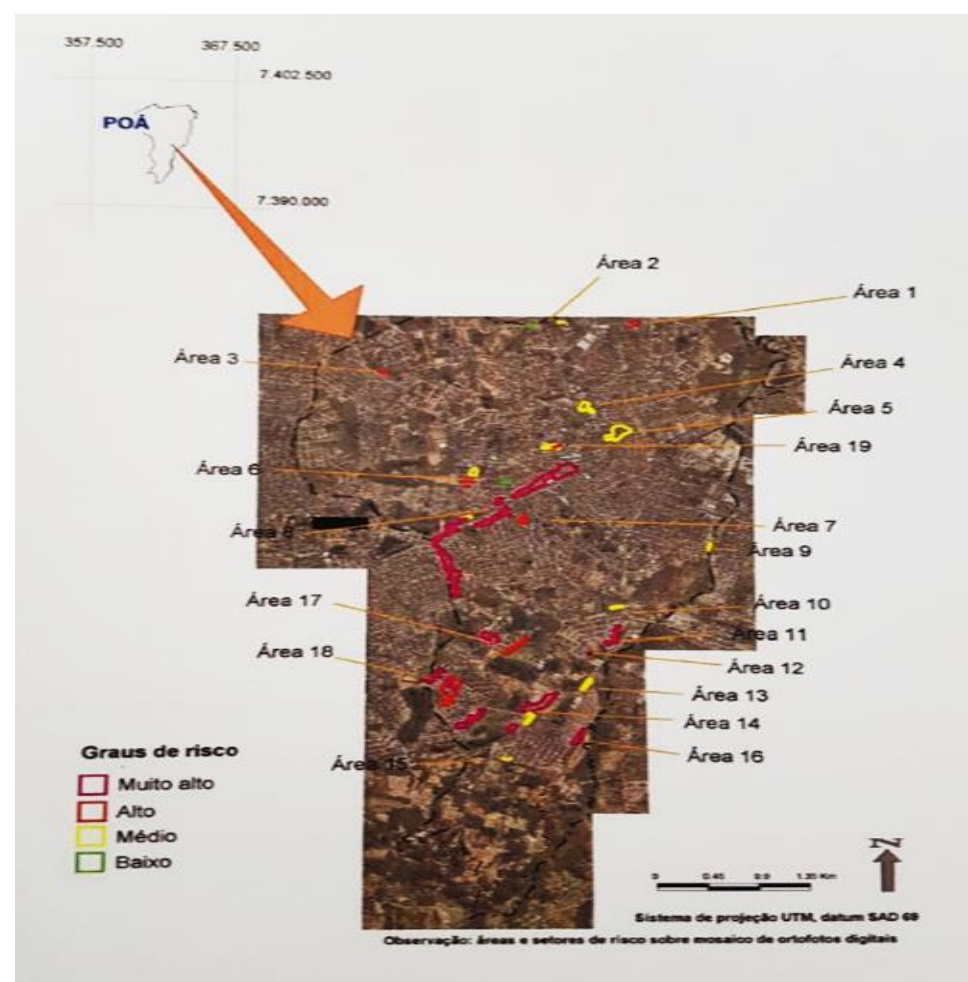

Gráfico 03: localização das 19 áreas de risco no mapa do Município de Poá-SP, conforme o laudo. Fonte: Relatório técnico do Instituto Geológico

Diante deste laudo técnico, no ano de 2013, o Ministério Público Estadual, por meio de seu Grupo de Atuação Especial de Defesa do Meio Ambiente - GAEMA, instaurou Inquérito Civil que teve como resultado a propositura de dezenas Ações Civis Públicas em face da Prefeitura de Poá-SP. Nas ações solicitava-se, liminarmente, a remoção de todas as famílias residentes nas áreas de risco, em prazo 
de até 120 dias, com a demolição de todas as construções. Havia o requerimento, ainda, de todas as medidas repressivas e preventivas das infrações na ocupação do solo, utilizando-se do poder de polícia.

No mérito, pedia-se reparação dos danos urbanísticos mediante a regularização do solo; remoção dos ocupantes das áreas, "proporcionando-Ihes moradia condigna em próprios municipais (bens dominicais) ou em áreas sem restrições ambientais, urbanísticas e legais, no prazo máximo de um ano". Caso não fosse possível o pedido anterior, solicitava-se a urbanização do núcleo habitacional com a manutenção dos ocupantes e a realização de obras de infraestrutura, segundo as exigências técnicas feitas por órgãos públicos de regularização.

Por fim, requeria-se a reparação dos danos ambientais com a desocupação das áreas onde eram proibidos o desmatamento, recobrimento do solo destas faixas, realização de obras de despoluição de cursos de água, afastamento das áreas de proteção ambiental dos sistemas de esgoto sanitário, entre outras medidas mitigadoras.

O Parquet afirmava na petição inicial que o município, apesar de ter em mãos o estudo, se limitou a propor execução de obras de drenagem e pavimentação, as quais seriam insuficientes. Acrescentou que as construções não eram licenciadas, e que o Município apenas fez o cadastro das famílias, sem realizar nenhuma obra para eliminar os riscos.

Nos fundamentos jurídicos se colocou a necessidade da propriedade servir de instrumento para conservação do meio ambiente ecologicamente equilibrado; a obrigação do município em promover o ordenamento territorial pelo planejamento e controle do uso parcelamento e ocupação do solo; necessidade do uso do poder de polícia da administração pública para demolir obras clandestinas; elencou a obrigação dos municípios assegurarem o pleno desenvolvimentos das funções sociais da cidade e garantia do bem estar dos habitantes, utilizando-se do Plano Diretor como instrumento básico dessa política.

Em relação à violação ao direito urbanístico, o Ministério Público cita José Afonso da Silva como doutrina abalizada, concluindo que "não se trata de mera faculdade do Município a regularização de construções clandestinas ou irregulares", assim o poder discricionário não teria lugar e a indiferença do Poder Público ofende direitos e interesses difusos, coletivos e individuais disponíveis. 
Por fim, o Parquet trata de violações de outros direitos sociais, abordando o grande fluxo populacional em Poá, que gerou ocupação desordenada em seu território, mas que o Município optou por não regular o uso do solo. Assim estariam sendo violados os direitos à vida, à saúde, segurança, moradia e saneamento básico. O órgão ministerial reconhece que não há política habitacional para as famílias que residem nestes locais, estando violados seus direitos, entretanto, a peça processual não traz uma conclusão sobre qual seria a obrigação do Município diante deste quadro, limitando-se a fazer este exercício no aspecto ambiental.

\subsubsection{A inserção do Ministério Público no campo jurídico pela questão ambiental}

O Ministério Público é um ator de elevada posição hierárquica no campo jurídico não apenas por ser um ente estatal, mas por trazer uma legitimação constitucional de ser o defensor da ordem jurídica, do regime democrático e dos interesses sociais e individuais indisponíveis (art. 127, CF). Há uma construção retórica em torno desta instituição como a encarnação da própria neutralidade, como se o ordenamento jurídico ou a democracia tivessem algum sentido imanente e que o Ministério Público seria o responsável por proteger tal entendimento. Esta concepção traz um local de fala privilegiado ao denominado Parquet, pois suas manifestações jurídicas partem com a credibilidade de quem é instituído como um guardião da Constituição.

Em uma concepção de direito como campo jurídico, sabe-se que toda argumentação, as categorias, conceitos, são fruto de um trabalho histórico de especialização em que atores que detém o poder de nomeação, definem as coisas, estabelecem visões de mundo e resultados esperados, produzindo o mundo social. 0 Direito, portanto, não é apenas definido previamente, é construído na prática, estando em constante formação. Assim, se uma instituição é nomeada como a protetora da ordem jurídica, a tendência é que seja patrocinadora da noção majoritária acerca dessa ordem, a qual é formatada pelo entendimento de seus poderes dominantes.

Há uma intensa disputa discursiva em torno da questão ambiental, de forma que o estabelecimento do Ministério Público como protetor do meio ambiente enquanto direito difuso, volta-se a um pressuposto de visão universalista, em que o direito ao meio ambiente seria um bem comum, devendo ser preservado para as presentes e futuras gerações. Entretanto a vocação universalista não está isenta de 
questionamentos, pois os custos e os benefícios de sua proteção são desigualmente distribuídos, variando em função dos recursos de que dispõem os diversos grupos para atuar no contexto da política local (FUCKS, 1998, p. 04).

Assim, no debate público há uma tendência ao universalismo ao tratar da defesa do meio ambiente natural como um direito de todos. Porém, há um viés particularista ao abordar apenas a favelização como responsável pela degradação das áreas naturais, colocando o foco do problema não no processo de desigualdade econômica, mas em uma característica social de uma classe inferior e como um problema meramente urbano.

No caso em observação, houve a utilização de um relatório técnico que apontava riscos geológicos para fundamentar o pedido de remoção imediata de todas as famílias localizadas nestas regiões, com medidas repressivas em relação a ocupação irregular do solo urbano. Os fundamentos centrais do órgão ministerial eram: a) a necessidade de preservação do meio ambiente - de onde decorriam diversos pedidos de reparação ambiental e desocupação - e; b) obrigação do município em promover o ordenamento territorial pelo planejamento e controle do uso parcelamento e ocupação do solo. Havia, portanto, uma preocupação ambiental e outra urbanística que parecem indissociáveis.

A postura radical de exigir uma intervenção de grande proporção, implicando a remoção de milhares de famílias se encaixa no repertório argumentativo que Mário Fucks (1996, p. 8-10) de ideologia pura da ordem, em que o ponto central é combater a todo custo, em todas as frentes a desordem urbana, tendo como finalidade o uso racional do espaço. Assim, é importante que todos os que contribuem para este caos sejam responsabilizados, devendo o Estado impor a lei. No caso em análise, os maiores responsáveis elencados são os moradores que ocuparam irregularmente o solo urbano e, especialmente, o Município que se omitiu em realizar suas atribuições.

Desta maneira, o caso ilustra como o Ministério Público se afigura como mais um partícipe do campo jurídico que afirma uma retórica jurídica, construindo conceitos sobre o que é o direito ambiental a partir do meio ambiente natural e do direito urbanístico como a necessidade de parcelamento do solo urbano.

Apesar de a principal consequência direta das ações ser a possibilidade de remoção de milhares de famílias, não há a mesma preocupação na formulação dos pedidos sobre a destinação habitacional, se comparados com os pedidos de recuperação e preservação ambiental. Faz-se o pedido de enviar as famílias para 
imóveis públicos (bens dominiais) e, na impossibilidade, regularizá-los em outro local no prazo de um ano, ou seja, um pedido irreal posta a impossibilidade do surgimento de milhares de moradias neste período.

Estas concepções demonstram uma noção idealizada do Direito, que não consideram as vicissitudes da realidade, que considerem os motivos históricos e sociais que geram a ocupação destes terrenos por moradores de baixa renda ou qualquer outra ponderação, exigindo-se apenas a aplicação da literalidade da lei.

\subsubsection{A linguagem dos moradores e a cisão profanos/profissionais}

A propositura das ações civis públicas (ACP) teve efeito imediato. Em 22 de outubro de 2013 moradores do Jardim Débora, localizado no Município de Poá-SP, compareceram no Núcleo de Habitação e Urbanismo acompanhados do vereador Antônio Nobre Ramos (PDT) e seus assessores, informando sobre o risco que as ações geravam para suas moradias, que estavam estabelecidas havia mais de 20 anos. Em datas posteriores compareceram no atendimento do Núcleo de Habitação outros moradores relatando que havia sido concedida tutela antecipada em uma das ACP's, determinando sua remoção.

O caso teve grande repercussão midiática, inclusive em uma das matérias jornalísticas ilustra-se a visão de um dos moradores dos locais atingidos pela discussão judicial, o senhor Anderson João da Silva, o qual afirmava que "os moradores não concordam com a determinação da Justiça. Meu pai pegou o terreno em 1970 e moramos aqui até hoje. Pagamos água, esgoto, não podemos sair daqui como lixos"32. A narrativa do morador revela que a população tem sua interpretação sobre o Direito, baseada em noções como aquisição onerosa do terreno, tempo de uso do solo, pertencimento ao local e legitimação de sua posse pelo acesso a serviços.

Como a formação do campo jurídico é feita por meio de uma concorrência pelo monopólio do acesso aos meios jurídicos herdados do passado, o discurso do morador também é uma interpretação sobre o conflito que é colocada em disputa. Os meios jurídicos, entretanto, são formados por ritos, procedimentos e conceitos que os colocam em uma posição desigual no trabalho de definição da pertinência da continuidade de sua

32 Justiça determina retirada de 1,5 mil famílias de áreas de risco em Poá. Portal G1. São Paulo, 18 jan. 2018. Disponível em: http://g1.globo.com/sp/mogi-das-cruzes-suzano/noticia/2013/11/justicadetermina-retirada-de-15-mil-familias-de-areas-de-risco-em-poa.html 
moradia. O constante trabalho de racionalização no campo jurídico faz com que a percepção de justiça do morador pareça mera atecnia ingênua, enquanto a tradução do conflito para a linguagem das normas ganha a aparência de sentido de verdade e de independência das relações de poder (a esta cisão Boudieu denomina como a separação entre os profanos e os profissionais).

A existência de instituições como a Defensoria Pública representa para a população um mecanismo no campo jurídico com maior capital simbólico, abrindo possibilidades de mais amplas de êxito processual. Por outro lado, esta instituição absorve grande parte das demandas, impedindo que movimentos sociais busquem maior representatividade no campo jurídico, adquirindo seu próprio capital simbólico. Ao mesmo tempo em que a Defensoria Pública se apresenta como um representante de atores na luta por cidades menos desiguais, galgando vitórias importantes, também serve como elemento de refreamento de uma maior radicalidade. A absorção das pretensões de centenas de atores em apenas uma instituição permite que se padronize seu discurso, tornando as articulações no campo jurídico mais previsíveis, além de reduzir as possibilidades de novos atores ganharem maior hierarquia no campo, pois seus anseios são delegados.

A leitura de que a disputa possui grande desigualdade, faz com que os moradores busquem todos os apoios possíveis, como a de parlamentares, que acabam fazendo parte da construção de sentido jurídico ao conflito, ao colocarem sua representatividade na disputa. Na esfera política, logicamente, o caso teve ampla repercussão, servindo como pauta para outros vereadores como Jeruza Lisboa Pacheco Reis (PTB) ${ }^{33}$ e Antônio Nobre Ramos (PDT).

\subsubsection{As diferenças entre o discurso jurídico e a imposição da realidade}

O fato de o Ministério Público conduzir todas as medidas, por meio de um Inquérito próprio, culminando com a propositura de ACP's, Ihe garante uma maior legitimidade, pois traz consigo um discurso de quem está exercendo ativamente o papel de um bom fiscal. No caso em análise, nota-se que esta instituição tende a fazer uma função de pouca flexibilidade, o que coaduna com a ideologia ambiental da pura ordem.

33 Vereadora Jeruza ataca promotor e não quer remoção. Blog de Poá. São Paulo, 19 jan. 2018. Disponível em: http://www.blogdepoa.com.br/2013/10/vereadora-jeruza-ataca-promotor-e-nao.html 
Diante disso, ciente de que o Ministério Público faria uma reunião com a Prefeitura e Vereadores de Poá para instrução de seu Inquérito Civil, o Núcleo de Habitação solicitou participação considerando-se a situação dos moradores do Jardim Débora. Todavia, o pedido foi indeferido pelo Promotor de Justiça responsável pelo caso, sob a justificativa de que a reunião não tinha como objeto de discussão apenas o caso destes moradores. A Defensoria, em contrapartida, renovou o pedido, esclarecendo que também acompanhava a situação de forma mais ampla que o interesse apenas daquela comunidade, mas que poderia permanecer na reunião apenas no que tocasse à questão dos moradores. A coordenação do Núcleo de Habitação, assim, foi admitida na reunião.

No evento, o Ministério Público se apresentou bastante resistente às colocações da Prefeitura ${ }^{34}$, porém informou que se houvesse comprovação da eliminação dos riscos para as moradias, não iria promover a desocupação e remoção das famílias. Deste modo, ficou acertado que a Prefeitura encaminharia os cronogramas de obras para resultar em acordos nas ações judiciais. Na reunião também houve a presença de vereadores, o que ilustra como tais ACP's dominaram a agenda e os debates do município.

$O$ fato é que as ações fizeram a Prefeitura agir de modo emergencial e, entre suas medidas, foi solicitada nova vistoria técnica nos locais no ano de 2013 , tendo em vista que uma das críticas que as ACP's sofriam era o fato de se embasarem em laudo técnico elaborado em 2006, o que poderia implicar em defasagem em relação à realidade atual. A Coordenação do Núcleo de Habitação, em diálogo com agente responsável pela Defesa Civil de Poá, foi informada que o mapeamento de 2006 feito pelo Instituto Geológico sofria críticas por técnicos da Prefeitura, pois não levava em consideração o solo, nem individualizava as casas. Ainda assim, a Secretaria de Obras de Poá informou que a Prefeitura estava fazendo obras para contenção de risco, em especial na área do Jardim Áurea.

Em fevereiro de 2014, algumas das ACP's tinham tutela antecipada concedida para remoção das famílias, porém a Prefeitura ainda não havia sido intimada, não dando cumprimento. Além disso, o Promotor que conduzia o caso alegava que não faria acordo em relação à área de preservação permanente, em torno dos córregos, exigindo recuo de 30 metros em todo e qualquer caso. Por outro lado, a Secretaria de

${ }^{34}$ Certidão de fl. 240 do Procedimento Administrativo NEHABURB no 70/2013 
Obras do município informava, em base técnica, que por se tratar de área bastante consolidada, o recuo de 5 metros seria suficiente para evitar remoções e possibilitar a limpeza dos córregos.

A Prefeitura encaminhou, em janeiro de 2014, uma proposta de intervenções na Área 17, definindo os tipos de obras para redução de riscos, cronograma e orçamento de gastos em $\mathrm{R} \$ 2.684 .642,26$. A Defensoria Pública identificou boa vontade da Prefeitura em solucionar o caso, apontando apenas a necessidade de especificar com mais acuidade que tipos de remoções deveriam ser feitas, ou seja, se seriam provisórias ou definitivas, conforme o tipo de risco.

A Prefeitura solicitou um estudo à Secretaria do Meio Ambiente para demonstrar a consolidação da ocupação em áreas de proteção. Memorando interno da Prefeitura de Poá informava que os loteamentos em questão foram implantados há, pelo menos, 40 anos, alguns com aprovação pela municipalidade. A Secretaria de Obras da Prefeitura aguardava o aval do Ministério Público em relação ao seu cronograma de obras, porém em março de 2014 ainda não tinham recebido qualquer resposta.

$\mathrm{Na}$ verdade, não estava ocorrendo nenhuma remoção de famílias, demonstrando-se que, apesar da propositura de dezenas de ações, os agentes envolvidos entendiam a magnitude do problema de aplicação da remoção de milhares de famílias. Os fatos foram demonstrando esta realidade, de forma que a discussão foi se reduzindo para a necessidade de obras de contenção de riscos, restando uma controvérsia em relação às áreas de preservação permanente.

O caso relatado, portanto, apresenta a inviabilidade do pensamento sistemático nesta aporia, pois a lógica de meio ambiente e parcelamento como imposição da ordem, partindo do sistema normativo, não consegue oferecer soluções viáveis. Aos poucos os atores envolvidos foram encontrando um consenso, a partir do problema, que demonstrava a inviabilidade da maior parte dos pedidos formulados nas ACP's do Ministério Público.

\subsubsection{A atuação da Defensoria Pública}

Os moradores que, inicialmente, buscaram a Defensoria Pública foram os das regiões denominadas Cidade Kermel, Jardim Débora e Jardim Madre Ângela. Foram propostas duas Ações Civis Públicas em favor das duas primeiras comunidades. Em 
relação ao Jardim Madre Ângela, novo laudo produzido pelo Instituto Geológico demonstrou que havia duas casas em risco de escorregamento do solo, em área de preservação permanente, de forma que a Defensoria optou por não realizar intervenção judicial em sua defesa, em razão do risco para vida em caso de permanência no local, além de entendê-la como impossível juridicamente.

$\mathrm{Na}$ ACP, a Defensoria Pública destaca o relatório técnico utilizado pelo Ministério Público, o qual recomendava doze tipos diferentes de intervenções nas áreas de risco, mas nenhuma delas seria a remoção definitiva das famílias, o que dependeria de análises e estudos mais detalhados. A opção pelo desalojamento era colocada apenas como medida preventiva naquele relatório. Assim ressaltou-se que o conceito de risco geológico-geotécnico representa uma probabilidade de ocorrer evento adverso, mas que pode ter seus efeitos reduzidos pelo grau de gerenciamento adotado pelos agentes públicos e pela própria comunidade.

O Núcleo de Habitação e Urbanismo ressaltou a necessidade de um laudo técnico mais recente e específico, de haver defesa efetiva pelos moradores, lesão à dignidade das pessoas e ao direito de moradia. A instituição, portanto, trazia um discurso que buscava topoi centrados na figura humana, nos riscos ambientais envolvendo a ação humana. A partir destes topoi nota-se que foi proposto um debate sobre a desigualdade ambiental, em que os pobres são mais expostos aos riscos gerados pela produção econômica que concentra riqueza, pois o mercado de terras faz que com que as práticas danosas se localizem nas áreas desvalorizadas.

Deste modo, se há a necessidade de se cobrar a implementação de políticas públicas do município, estas não deveriam ser pensadas em uma lógica de revitalização do meio ambiente natural ao status existente há décadas. A noção trabalhada passa a exigir a recuperação das áreas por meio de regularização fundiária, permitindo uma ocupação do solo mais racional, com acesso à moradia, saneamento básico, infraestrutura urbana e demais serviços, que redistribuam os benefícios do desenvolvimento, permitindo que a relação daqueles moradores com 0 ambiente seja mais sadia.

Forma-se, portanto, a chamada aporia, em que surgem posições inconciliáveis, exigindo o agir comunicativo, em busca de um consenso entre as partes, conforme detalhado por Viehweg. Destaque-se, que a Defensoria Pública citou como um dos dispositivos legais para o caso o artigo 3-B da Lei 12.340/2010 (Sistema Nacional de Defesa Civil), que coloca a remoção das pessoas como opção apenas como última 
alternativa, mas garantindo atendimento habitacional. O raciocínio que esta norma traz, em contraposição com o alegado pelo Ministério Público, revela a grande dificuldade do pensamento sistemático trazer soluções para as aporias, pois o próprio sistema apresenta contradições inconciliáveis ou lacunas que não permitem resposta para casos concretos, exigindo o pensamento problemático.

Em continuidade, foram apresentados pedidos para que o poder municipal se abstivesse de remover as famílias; realizasse estudos técnicos específicos para cada área; executasse as obras necessárias para a remoção dos riscos, eliminando-os; realizasse a regularização fundiária e urbanística do terreno. Caso houvesse remoções, solicitava-se que houvesse o atendimento habitacional provisório, vinculado a um definitivo.

A importância da propositura de outra ACP era mudar o eixo central do debate estabelecido nas ACP's do Ministério Público, pois a mera apresentação de defesas estaria inserida no contexto de defesa do meio ambiente. A Defensoria Pública, ao fim, propôs Ações Civis Públicas na defesa das comunidades Cidade Kermel, Jardim Débora, Jardim Áurea, Jardim Nova Poá, Vila São João ${ }^{35}$. Houve, ainda, a defesa de moradores de outras áreas, porém por ações individuais, dado o número reduzido de moradias com risco real de remoção.

\subsubsection{O resultado das Ações Civis Públicas no Poder Judiciário}

A recepção pelo Poder Judiciário das ACP’s propostas pelo Ministério Público foi feita de forma bastante diversificada, pois estas foram distribuídas em Juízos diferentes, tendo em vista que a comarca de Poá tem mais de uma vara judicial. No julgamento dos pedidos de tutela antecipada houve juízes que concederam o pedido, incluindo a remoção das famílias. Entretanto, a maior parte das decisões optou pela manutenção temporária dos moradores nas áreas de risco - alguns negando todo o pedido de tutela antecipada e outros exigindo a realização das obras de infraestrutura e recuperação ambiental em prazos de 120 dias.

Esta posição majoritária de manutenção dos moradores reafirma 0 entendimento de que o Judiciário não tem em um julgamento, como meta central, o estabelecimento do que a lei determina ou a garantia de direitos, mas a absorção de

35 Procedimentos Administrativos no 31/2015; 07/2016; 38/2016; 39/2016; 40/2016. 
insegurança. A remoção imediata de milhares de famílias, assim como a imposição da realização de obras sem previsão orçamentária, geraria a possibilidade de transtornos ainda maiores ou até mesmo a impossibilidade de cumprimento da ordem judicial, o que resulta na perda de credibilidade do Poder Judiciário.

Ante a dimensão da questão, que envolvia todo um município, questionando um conjunto de políticas públicas em 19 áreas de risco, foi realizada audiência de conciliação no dia 27 de setembro de 2017, em que foram estabelecidas as medidas a serem adotadas pelo Município para sanar os riscos. A Prefeitura se comprometia a apresentar, em 60 dias, relatório especificando as áreas que ainda se encontravam em situação de risco, individualizando as residências e seu grau de risco. Discriminação das obras ou medidas a serem adotadas, realizando notificação dos moradores a serem afetados, definindo prazo para sua conclusão.

Em relação às áreas de preservação permanente, a municipalidade se comprometeu a apresentar relatório sobre estas regiões, especificando as residências em conflito com a legislação, mas podendo apresentar projeto de descaracterização das APP's, regularizando as ocupações. Onde não fosse possível a permanência, haveria a remoção. A audiência foi realizada nos autos do processo $\mathrm{n}^{0}$ 100084883.2016.8.26.0462, porém englobou outras 10 Ações Civis Públicas, permitindo que a solução enquadrasse quase todas as áreas colocadas em Juízo. O resultado apresentado em audiência de conciliação evitou a remoção das pessoas, preocupando-se antes com a eliminação de todos os riscos. Até mesmo na questão das APP's, que era o ponto de maior resistência do Ministério Público, permitiu-se a continuidade das ocupações, onde os estudos mostrassem que fosse viável.

O caso revela como um agente imbuído de grande legitimidade no campo jurídico utilizou-se de uma estratégia de "choque", colocando o município de Poá em uma situação de crise, o que envolveu atores do Poder Executivo, Legislativo, Judiciário e Defensoria Pública, além de diversos profissionais para que se encontrasse uma solução razoável. Não é possível saber se a propositura das ações exigindo a remoção imediata de milhares de famílias era mera estratégia ou fazia parte da visão jurídica, social e ambiental do Ministério Público. A conclusão processual do caso, entretanto, se alinhou mais à retórica dos técnicos municipais e da Defensoria Pública, que era mais condizente com a preservação não apenas das moradias, mas da estabilidade do Poder Executivo municipal. 
A resolução da questão em audiência de conciliação demonstra que todo o pensamento do caso foi feito de forma problemática, visando à superação da aporia, buscando nos topoi a argumentação para um consenso entre as partes, o que aconteceu na audiência de conciliação. Em situações extremas e inconciliáveis, a sistematização de normas leva a lacunas, em que qualquer decisão fundamentada unicamente nas normas pode conduzir a graves problemas sociais ou, até mesmo, na perda de credibilidade das instituições, que se mostrariam totalmente inaptas a solucionar o problema. 


\subsection{CASO 04: A LUTA PELA LOCAÇÃO SOCIAL}

O direito social à moradia é bastante vinculado com a propriedade de uma casa. No Brasil, as formas de provimento de moradia por políticas públicas ocorrem, primordialmente, pelo subsídio de financiamentos para aquisição de habitações, tendo como principais referenciais históricos o Banco Nacional de Habitação - BNH, a partir dos anos 1960 e o Programa Minha Casa Minha Vida - PMCMV, a partir de 2009. O "sonho da casa própria", portanto, é um conceito enraizado na sociedade, como um marco de aquisição de direitos, entretanto, há outras formas de provimento de moradia que se focam no valor de uso do imóvel.

A locação social é um instrumento que permite ao Estado locar imóveis públicos ou privados para famílias, de modo subsidiado, cobrando valores bastante reduzidos de aluguel. A medida tem grande relevância para grupos como população em situação de rua ou idosos, que não conseguem acessar o mercado formal de financiamento público, seja pela falta de rendimento suficiente ou pela idade avançada. Além disso, há a vantagem de que a titularidade do imóvel continua com o Estado, evitando que o usuário venda o bem, o que desvirtuaria a finalidade da política.

Este tipo de fornecimento de moradia, inclusive, é uma iniciativa amplamente aplicada em países da Europa, onde a porcentagem do estoque habitacional público é elevada, como por exemplo: Bélgica (7\%), Alemanha (40\%), Reino Unido (11\%) e França $(20 \%)^{36}$. Em um país como o Brasil, portanto, que possui elevado déficit habitacional, em que apenas políticas de financiamento subsidiado não conseguem superá-lo, a implementação desta política revela-se como fundamental para garantir com plenitude o direito à moradia.

Neste sentido, a Defensoria Pública instaurou Procedimento Administrativo de Investigação Preliminar, no dia 22 de março de 2012, no intuito de averiguar se o Governo do Estado de São Paulo tinha em execução algum programa de Locação Social fundado na Lei Estadual ํㅜ 10.365/99. A referida legislação autorizava o Estado de São Paulo a implantar o Programa de Locação Social para prover moradias a famílias de baixa renda, por meio de locação de imóveis de particulares; por

${ }^{36}$ Debate no Centro Gaspar Garcia aborda locação social para população em situação de rua. Centro Gaspar Garcia de Direitos Humanos. São Paulo, 20 jan. 2018. Fonte: http://gaspargarcia.org.br/noticias/debate-no-centro-gaspar-garcia-aborda-locacao-social-parapopulacao-em-situacao-de-rua/ 
desapropriações, em situações de emergência; ou outorgando permissões de uso, quando fossem imóveis da Administração Estadual.

A Secretaria de Habitação Estadual, em resposta, afirmou que a referida legislação não fora regulamentada, de modo que havia apenas previsão de "auxílio moradia provisório". Por este benefício, a Companhia de Desenvolvimento Habitacional e Urbano - CDHU pagaria um valor para que famílias removidas para implantação de projeto de urbanização pudessem buscar uma moradia provisória. O Governo do Estado ainda possuiria o benefício "auxílio moradia emergencial", que visava transferência de recursos aos Municípios que declarassem estado de emergência ou calamidade pública, mediante convênio entre Secretaria de Habitação e CDHU.

Diante das informações, foi realizado relatório pelo Núcleo de Habitação e Urbanismo em que se considerou constatada violação ao direito à cidade e à moradia digna, em decorrência de omissão na concretização de política pública de desenvolvimento urbano por meio de programa de locação social. No relato considerou-se a necessidade da garantia de moradia para a população não apenas pela "casa própria", ou seja, pela propriedade, mas também a possibilidade de realização de políticas de locação.

Além disso, avaliando-se o princípio da gestão democrática das cidades na formulação e execução de planos de desenvolvimento urbano, nos termos do art. $2^{\circ}$, II, da Lei no 10.257/01 - Estatuto da Cidade, encaminhou-se ofício para o Conselho Estadual de Habitação - criado pela Lei Estadual № 12.801/08. O referido conselho tinha como atribuição promover ações para o desenvolvimento da política estadual de habitação de interesse social, assim foi feito o questionamento sobre a existência da política de locação social e sobre a possibilidade de realização de pesquisas, seminários, debates, com participação da Defensoria Pública, para levantar a temática da locação social estadual, visando sua implementação.

O uso do topos da gestão democrática das cidades, ao invés do direito à moradia, revela que o Núcleo de Habitação e Urbanismo entendeu que o problema central a ser solucionado não seria a ausência do programas de locação social pelo Governo Estadual. A reivindicação de um pressuposto de democracia participativa, demonstra uma preocupação com a elevada probabilidade do Poder Judiciário se negar a intervir no caso alegando a independência do Poder Executivo, que teria discricionariedade para avaliar a implantação da política pública. Pelos relatos dos 
casos anteriores percebe-se como este argumento é corriqueiro, mas é utilizado de acordo com os interesses em jogo, pois em um mesmo caso o Poder Judiciário traz decisões opostas negando ou permitindo tal interferência, ou mesmo o Ministério Público que quando autor de ações exige tal intervenção, mas como custos legis confere pareceres contra o direito solicitado baseado na independência do Poder Executivo.

É sabido que o Poder Judiciário tem grande resistência em impor o cumprimento de políticas habitacionais, ao contrário do que acontece com políticas de saúde, por exemplo. Os casos apresentados indicam que os julgamentos chegam a tratar do direito à moradia até mesmo como norma de eficácia plena - sem necessitar de norma regulamentadora - porém quando a decisão não conduz a um conflito institucional. A Defensoria Pública, portanto, buscou os topoi que direcionassem o discurso para a participação social como elemento elaborador daquela política, por compreender que apenas uma forte mobilização social poderia se sobrepor a uma resistência conhecida do Poder Judiciário em impor políticas habitacionais ao Poder Executivo.

Não houve, portanto, a tentativa de uma determinação imediata para que se fizesse uma norma regulamentadora, o que seria viável juridicamente, pela interposição de um mandado de injunção ${ }^{37}$, fundamentado no art. $7^{\circ}$ da Lei Estadual no 10.365/99 que dispõe que haveria regulamentação pelo Poder Executivo em 90 dias contados de sua publicação. A Defensoria Pública buscou uma via em que fosse catalizadora de um processo de participação social, provocando o Conselho Estadual de Habitação e evitando a judicialização da questão.

Em 07 de novembro de 2012, foi recebido ofício encaminhado pela Chefia de Gabinete da Secretaria de Habitação, reafirmando que o Estado possuía os benefícios do "auxílio moradia provisório" e do "auxílio moradia emergencial", sem qualquer satisfação quanto aos questionamentos acerca da locação social e regulamentação da legislação com participação social. Ante a omissão, foi reiterado o ofício da Defensoria Pública com a mesma problematização em 18 de janeiro de 2013,

37 O Mandado de injunção é denominado com um "remédio constitucional", em que se ingressa com este instrumento no Poder Judiciário para enfrentar omissão relacionada à regulamentação da lei no caso concreto. Nos termos do art. $5^{\circ}$ LXXI da Constituição Federal, "conceder-se-á mandado de injunção sempre que a falta de norma regulamentadora torne inviável o exercício dos direitos e liberdades constitucionais e das prerrogativas inerentes à nacionalidade, à soberania e à cidadania". Em outras palavras, havendo ausência de regulamentação da Lei Estadual no 10.365/99, gerando lesão ao direito constitucional à moradia ou à cidade, torna-se cabível o mandado de injunção. 
entretanto, não houve qualquer resposta. Ante a ausência de alternativas, o Núcleo de Habitação foi obrigado a decidir pela propositura do mandado de injunção em 17 de janeiro de 2014.

\subsubsection{A propositura de Mandado de Injunção}

Considerando-se que a locação social tem grande utilidade para a população idosa - tendo em vista que a aquisição de moradias pelo mercado ou até mesmo por políticas sociais de subsidiamento de financiamento habitacional é dificultosa, em razão da baixa expectativa de vida deste grupo - o Núcleo de Habitação se reuniu com representantes do GARMIC - Grupo de Articulação para Moradia do Idoso na Capital, para ingressarem com o Mandado de Injunção. A referida ação constitucional tem como pressuposto a demonstração em um caso concreto, a violação de direitos pela omissão estatal, assim era trivial a parceria com um movimento social que representasse um grupo social vulnerabilizado pela ausência de políticas públicas de locação social.

Finalmente, em 04 de setembro de 2014, houve reunião com lideranças do GARMIC, as quais apresentaram rol de idosos cadastrados na lista de espera de financiamentos da CDHU (247 pessoas), com renda abaixo de um salário mínimo e residentes em moradias precárias alugadas ou em albergues. Na oportunidade, as representantes do GARMIC afirmaram que a falta de atendimento levava, em alguns casos, a suicídio por muitos idosos.

Para instruir o mandado de injunção, foi expedido ofício ao Conselho Municipal de Habitação, requisitando informações sobre a existência de política de locação social no Município de São Paulo, assim como todos as normas e documentos sobre o tema, de forma que servissem como parâmetro de comparação. O ofício foi respondido, acompanhado de diversas normas, especialmente pela Resolução CFMH no 23/2002 e Instrução Normativa no 01/2003, as quais regulamentaram o programa em nível municipal.

Finalmente, em 13 de outubro de 2015 foi protocolado o Mandado de Injunção perante o Órgão Especial do Tribunal de Justiça de São Paulo ${ }^{38}$ (Processo no

38 O Órgão Especial é composto por 25 desembargadores: o Presidente do Tribunal, doze entre os mais antigos e doze eleitos - e possui sua competência definida no Regimento Interno do Tribunal de Justiça de São Paulo, entre os artigos 8 e 14. 
2216566-84.2015.8.26.0000), o qual foi recebido pelo Desembargador Relator. A ação foi proposta pelo GARMIC, na defesa dos interesses de seus membros, representados processualmente pela Defensoria Pública de São Paulo.

Em resposta, o Gabinete do Governo do Estado de São Paulo prestou informações sobre o caso (folhas 674 a 690 do processo), alegando que: a) já existiria norma regulamentando a locação social, isto é, o Decreto no 53.823/2008, que regulamentava a Lei Estadual no 12.801/08 (ambas as normas tratavam de autorização genérica do governo do Estado participar do Sistema Nacional de Habitação Social, sem definir qualquer política de locação social); b) havendo lei regulamentadora, o mandado de injunção não seria cabível, pois o GARMIC e Defensoria estariam querendo impor que o Poder Judiciário substituísse o Poder Executivo na instituição de política pública; c) a Lei Estadual o 10.365/99 apenas autorizava o Poder Executivo em locar imóveis para política habitacional, havendo mera faculdade e não obrigação.

Em síntese afirmava-se que a Lei Estadual oㅜ 12.801/08 incluía o Governo Estadual no Sistema Nacional de Habitação Social, que tinha como objetivo prover moradia e acesso à terra à população de baixa renda, deste modo, o Poder Executivo teria cumprido sua função normativa. Desta forma, a execução da política habitacional estaria sendo implementada de forma paulatina, não sendo cabível o Poder Judiciário opinar sobre o tema. O Governo Estadual apresentava como defesa legislações genéricas, ocultando que a Lei Estadual no 10.365/99 gera um compromisso com a sociedade para sua implementação, inclusive pela própria lei ter um dispositivo impondo sua regulamentação em 90 dias.

O Ministério Público de São Paulo apresentou Parecer (folhas 732 a 738 do processo), afirmando que no caso deveria ser analisado se a ausência de regulamentação da Lei Estadual no 10.365/99 resultaria em um efetivo obstáculo ao adimplemento do direito social à moradia digna aos idosos. O Ministério Público relata que "existe, sim, legislação estadual, ainda que de caráter genérico, regulamentando a concessão de moradia às pessoas naturais, também idosas, conforme assegurado nas Constituições". Desta forma, conclui que a averiguação de desamparo de idosos em seu direito de moradia, deveria ser feita em cada caso concreto, de modo que cada pessoa deveria fazer pedidos administrativos para o Poder Executivo, clamando pelo cumprimento da legislação existente. Na opinião, do Ministério Público, portanto, 
não caberia acolhimento o mandado de injunção, ainda que a legislação fosse genérica.

É visível a mudança de postura do Ministério Público no papel de "fiscal da lei" em comparação ao perfil quando é o litigante, demonstrado no caso das remoções de Poá. Nesta última situação, se exigiu a imposição de uma política pública integral de recuperação ambiental e de parcelamento do solo pelo Poder Executivo, afirmandose que a omissão justifica esta intromissão. Na locação social, o Parquet afirma que a mera legislação genérica tratando de políticas habitacionais supriria uma imposição da Lei Estadual no 10.365/99, não vislumbrando qualquer violação de direitos. Além disso, traz um argumento contraditório, ao alegar que os obstáculos ao direito à moradia deveriam ser analisados no caso concreto, entretanto, o mandado de injunção exige a análise concreta, especificamente, dos associados do GARMIC.

O Desembargador Relator proferiu seu voto, repetindo os mesmos argumentos colocados pelo Ministério Público, ao afirmar que a Lei Estadual oㅜ 12.801, regulamentada pelo Decreto $\cong 53.823$, possibilitaria a pessoas de baixa renda o direito à moradia, incluindo o idoso. Do mesmo modo, a Lei Estadual no 13.816/09, que implementa o Programa de Moradia ao Idoso asseguraria o direito social à moradia. Em 13 de abril de 2016, o Julgamento foi realizado pelo Órgão Especial do Tribunal de Justiça de São Paulo, participando do ato 25 Desembargadores, os quais denegaram o pedido de forma unânime, seguindo o voto do relator.

Na petição inicial formulada pelo GARMIC e Defensoria Pública foi explicado que "a locação social deve ser considerada como uma importante forma de implementação de moradia digna, principalmente ante ao atual cenário, onde o fornecimento de habitação por meio de programas de aquisção da casa própria é precário e insuficiente para alcançar toda a demanda habitacional do Estado". Em outras palavras, foi comunicado que a violação ao direito à moradia ocorria, pois a política de aquisição da propriedade de imóveis não era suficiente. Além disso, se a Lei Estadual no 10.365/99 traz a promessa de uma política de locação social, esta deve ser implementada, caso contrário, torna-se inviável ao cidadão alcançar este meio de provimento de moradia.

A despeito de tal distinção, mostrando-se que há formas diversas de implementação de moradias e da comprovação de que a referida lei estadual estava há 15 anos sem regulamentação (mesmo com a ordem de regulamentação em 90 
dias da publicação), o Tribunal de Justiça de São Paulo, por meio de seu órgão especial, entendeu de forma unânime que não haveria qualquer omissão estatal.

O GARMIC e Defensoria Pública ainda apresentaram embargos de declaração, afirmando que o julgamento teve omissões, entretanto, o recurso não foi acolhido e a ação transitou em julgado em 25 de novembro de 2016, após o Núcleo de Habitação optar por não levar o caso aos Tribunais Superiores.

Era evidente a omissão normativa do Governo Estadual, porém o caso demonstra novamente como as decisões não são formadas pelo pensamento sistemático, o que determinaria a regulamentação do programa de locação. 0 pensamento problemático, na lógica das relações de poder que envolvem o Judiciário, conduz a uma composição com os atores dominantes da hierarquia do campo jurídico, de forma que a manutenção de uma boa relação com o Governo do Estado, mantendo um debate jurídico razoável, é o problema central a ser resolvido. Assim, buscou-se uma justificativa simples de que o tema já estaria regulamentado, mantendo-se o status atual.

\subsubsection{Efeitos Políticos do caso}

O caso, portanto, não teve sucesso pela via judicial, contudo a propositura do Mandado de Injunção teve repercussão social, ampliando a repercussão da necessidade de locação social na agenda pública. Os resultados podem não vir no campo jurídico, mas tem reflexos em outros campos, como o político. Em 10 de outubro de 2016, a Deputada Estadual Márcia Lia (PT) recebeu os coordenadores do Núcleo de Habitação na Assembleia Legislativa e se comprometeu a defender a regulamentação da aludida legislação ${ }^{39}$.

Em consequência, a Deputada Estadual apresentou em 09 de dezembro de 2017 a Indicação ${ }^{40}$ no 4.076/2017 ao Governo do Estado de São Paulo para que este determine aos órgãos competentes, a realização de estudos visando à possibilidade de se implantar no Estado de São Paulo o Programa Aluguel Social, além disso, a

\footnotetext{
39 Regulamentação da lei de locação social no Estado. Agência de Notícias da Assembleia Legislativa do Estado de São Paulo. São Paulo, 20 jan.2018. Disponível em: https://www.al.sp.gov.br/noticia/?id=374279

40 Proposição pela qual são sugeridas, por Deputado ou Comissão, aos Poderes do Estado ou da União medidas de interesse público que não caibam em projeto ou moção de iniciativa da Assembleia Legislativa. São Paulo, 20 jan. 2018. Disponível em: https://www.al.sp.gov.br/alesp/projetos/?tipo=9
} 
indicação contém uma proposta de Projeto de Lei. O sítio eletrônico da Deputada informa que "a proposta foi construída com a participação de movimentos sociais, entidades e órgãos que trabalham junto ao mandato pela garantia dos direitos humanos e moradia digna"41.

A atuação da Defensoria Pública neste caso se iniciou por diversos atos administrativos como pareceres, relatórios e ofícios que trabalhavam uma noção sobre o direito à cidade e à moradia e buscava um processo de participação popular. A evolução dos conceitos, consolidando a visão que se tem dos direitos ocorre também na via extrajudicial. O Núcleo de Habitação chegou a solicitar até mesmo seminários e audiências públicas, o que seria etapa importante na construção de conceitos jurídicos como o direito à moradia pela locação social ou o direito de uso em relação ao direito de propriedade.

O que se traz de mais relevante neste caso, porém, é o fato de que a relevância da Defensoria Pública no campo jurídico não é suficiente para impor uma agenda pública por meio do campo jurídico, ainda que lastreada em clara disposição legal. Foi realizada uma estratégia com entidade social, entretanto não houve uma mobilização que envolvesse várias áreas sociais, gerando maior pressão no Poder Judiciário que os fizesse alterar a percepção de absorção de insegurança jurídica. A derrota na esfera judicial e os encaminhamentos no campo político trazem indícios de qual o caminho de atuação que o Núcleo de Habitação e Urbanismo pode ter para potencializar suas probabilidades de êxito, ainda que não venham na via judicial.

${ }^{41}$ Deputada Márcia Lia faz indicação de nova lei de aluguel social ao Governo do Estado. Site Deputada Estadual Márcia Lia. São Paulo, 20 jan. 2018. Disponível em: http://www.marcialia.com.br/deputadamarcia-lia-faz-indicacao-de-nova-lei-de-aluguel-social-ao-governo-do-estado/ 


\section{CONCLUSÃO}

Os conflitos urbanos da população de baixa renda, normalmente envolvendo a questão da habitação, de alguma forma são colocados em juízo, tornando o Judiciário um espaço de disputas. Nos quatro casos apresentados - que envolvem cerca de 18 Ações Civis Públicas, 01 Suspensão de Segurança e 01 Mandado de Injunção - houve decisões dos mais diversos tipos, seja afirmando ou negando o direito de moradia da população, interferindo ou não na independência do Poder Executivo. Em todas elas, entretanto, não se efetivou qualquer promoção de direitos que intercedesse de forma positiva na vida das pessoas, pois o máximo que se alcançou foi a possibilidade das famílias continuarem a residir em suas casas.

O discurso jurídico colocado nas decisões judicias - concedendo a procedência ou a improcedência das ações - possuem pouca relevância para entender efeitos na vida concreta das pessoas envolvidas, pois não passam de mascaramento da disputa de poder que impede que as pretensões da população pobre tenham êxito no alcance dos seus direitos. A representação de seus interesses pela Defensoria Pública possui importância, pois refere-se a uma instituição com a legitimidade de ser estatal, com estrutura, organização e orçamento maiores do que entidades privadas como associações, ONG's ou diversos escritórios de advocacia poderiam ter para sua defesa. Esses elementos permitem que a Defensoria Pública se construa como uma instituição com elevado capital simbólico, porém ainda insuficiente para galgar algo superior do que o poder de resistência.

Identificar se Defensoria Pública no campo jurídico possui uma posição dominada no campo jurídico - o que impediria uma maior inserção dos argumentos da população pobre - não é algo de fácil análise, nem de possível observação a partir dos quatro casos escolhidos. Entretanto, pode-se retratar que as hierarquias de divisão do trabalho jurídico no campo não são estanques e variam conforme as mudanças nas relações de força social, o que lança luzes para indicar possibilidades de mudanças.

O campo jurídico tende a expressar as formas de dominância no campo político e econômico, de modo que sua visão de mundo e princípios de vida acabam sendo normalizados e reforçados nas decisões judiciais. Em todos os casos havia noções 
sobre a cidade sendo trabalhadas por diferentes instituições, seja a cidade como parcelamento e uso do solo regulado - ignorando a informalidade - ou a cidade como um instrumento para negócios e acumulação de capital, mas em nenhum momento vingou uma percepção da cidade a partir do marginalizado. No caso 01 as Ordens Internas e o programa de remoções em áreas de mananciais foi mantido incólume pelo Poder Judiciário, assim como os leilões no caso 02 ou a manutenção da omissão em relação a política de locação social no caso 04 . No caso 03 há uma diferença por ter sido concluído por uma resolução negociada, em que se mantiveram as intervenções em áreas de risco, mantendo-se a maior parte das moradias no local.

As principais conquistas, entretanto, foram no campo político, com a modificação da regulamentação da Ordem Interna e sua revogação anos depois (caso 01); venda fracassadas dos imóveis dada a repercussão social negativa (caso 02); instalação de uma crise municipal em Poá que envolveu diversos atores políticos incluindo parlamentares - o que contribuiu para que a solução fosse pactuada (caso 03); levantamento da locação social na agenda pública, o que foi captado por uma deputada estadual (caso 04).

Estas consequências indicam que a maior possibilidade de mudança não está no campo jurídico, mas no campo político. Bourdieu explica que à medida em que aumenta a força dos dominados no campo social e a dos seus representantes no campo jurídico, a diferenciação tende a aumentar, alterando as relações de hierarquia. "É a intensificação da confrontação dos textos e dos procedimentos com as realidades sociais (...) que favorecem o aumento da diferenciação no campo e a intensificação da concorrência interna" (BOURDIEU, 2012, p. 253). Entretanto, esta tarefa de confrontação não é uma luta apenas de movimentos de luta por cidades democráticas ou de instituições e agentes que as representam no campo jurídico.

Conceitos tão arraigados na sociedade brasileira como o da propriedade detentora de poderes quase que absolutos, do Estado como representante do bem comum, do Poder Judiciário como uma instituição neutra e imparcial não são alterados tão facilmente, até porque o próprio campo reforça estas noções constantemente. Para se ter uma ideia do que seria necessário para algum tipo de transformação é importante observar como foi a luta contra a escravidão no Brasil, que era percebida pela população da época como um direito natural, em que o escravo não passava de uma propriedade. 
Ângela Alonso, em seu livro "Flores, votos e Balas" revela como uma verdadeira mudança de costumes, cultura, estilo de vida, que se refletiu em todos os hábitos da população, desde as relações privadas entre pais e filhos, até nos movimentos culturais fizeram parte de um repertório ${ }^{42}$ moral que foi determinante na luta abolicionista. $\mathrm{O}$ abolicionismo deixou de ser um ativismo de uma elite para verdadeiro movimento social.

O escravismo era visto como um estado de coisas natural, assim a retórica social era de defesa deste modelo econômico, de modo que suas atrocidades eram socialmente invisíveis. Sua deslegitimação teve como pilares o avanço tecnológico e a urbanização, o que alterou a hierarquia social, modificou o modo de vida rural para o urbano, trouxe costumes mais polidos, comportamentos mais contidos, novas profissões, vidas baseadas na educação e na ciência. Todas estas transformações trouxeram novas ideias, uma sensibilidade adequada a um estilo de vida moderno que contrastava com a rudeza da vida da fazenda.

As mudanças passaram para as artes, atingindo os romances, música, poesia, teatro, o que pode ser vislumbrado nas representações do romantismo brasileiro, em que se criavam novos arquétipos como o escravo nobre e fiel, a mãe escravizada por seu filho de leite, a moça conspurcada pela sexualidade de seu dono ou a humilhação da pessoa reduzida a objeto de compra e venda (ALONSO, 2015, p. 94). Tais imaginários desconstruíam a imagem do bom senhor em contraposição ao negro como uma ameaça, como escravo rebelde ou como mulata faceira, contribuindo para maior compaixão com os escravos e a causa abolicionista. Formava-se uma nova cognição em relação à escravidão, que deixou de ser naturalizada para ser associada à indignidade, injustiça e atraso.

Em outros âmbitos sociais novas ideias ecoavam, como nas faculdades, imprensa e nos livros, que difundiam ideias que viam o progresso como um processo inexpugnável, que acabaria com instituições tradicionais, trazendo a industrialização, urbanização e secularização do Estado. Assim, novas gerações de estudantes se tornavam prontamente abolicionistas, pois a conquista de mentes se dava também na academia, alinhada a uma visão positivista de progresso.

\footnotetext{
42 Angela Alonso, utilizando alguns teóricos, explica que repertório moral seria um conjunto limitado de esquemas de pensamento, padrões de sentido e de avaliação moral da realidade social disponíveis num dado tempo que simplificam o mundo e produzem orientação cognitiva para os atores durante as interações, ao demarcar possibilidade retóricas de justificação, oferecer uma "gramática de motivos" e estabelecer a "moralidade das reivindicações" (ALONSO, 2015, p. 379)
} 
Por fim, na esfera jurídica o conceito utilizado foi o do direito natural à liberdade - inerente à natureza humana - o tratado brasileiro com a Inglaterra de 1831 que tornava livres os africanos que entravam no país, assim como uma noção de liberdade como pressuposto para a cidadania. O maior referencial no uso da legislação dos escravistas contra seus próprios interesses, buscando alforrias e outros direitos para os escravos foi Luiz Gonzaga Pinto da Gama.

Luiz Gama explorava ambiguidades e lacunas da legislação escravista, solicitando no Poder Judiciário a anulação de títulos de propriedade de escravos; a ilicitude de situação de escravidão, por castigos físicos cruéis, o que havia sido proibido em dispositivos da Lei do Ventre Livre; ou se valia da previsão legal do pecúlio, em que o escravo poderia comprar sua própria alforria.

O estilo de atuação de Gama se espalharia para outros advogados, passando para faculdades de direito, que continha estudantes de todo o país. A judicialização do combate à escravidão se generalizaria nos anos 1880 com ações de liberdade, processos, apelos, denúncias aos tribunais, um ativismo judicial. Mesmo causas perdidas funcionariam com espaço para a ritualização do combate à escravidão (ALONSO, 2015, p. 106).

O exemplo histórico da luta abolicionista nos traz elementos para entender que conceitos naturalizados na sociedade são transformados por uma transformação geral de costumes, cultura que envolvem todos os aspectos da vida pública e, até mesmo, privada. Desde concepções filosóficas, religiosas, representações no campo das artes, ativismo de políticos, associações e, finalmente, de juristas fazem parte de um arcabouço geral de mudanças.

O Direito é acionado na politização dos conflitos, de forma que quando ocupantes lutam pela legalização de sua posse, eles atraem para sua arena outros atores até então não envolvidos na questão, agregando forças como advogados, Igreja, partidos políticos, imprensa, etc. (MOURA, 1990, p. 31). A Defensoria Pública foi chamada para estes conflitos a partir da luta de centenas de movimentos sociais por sua criação, o que resultou na elaboração de um Núcleo de Habitação e Urbanismo comprometido na defesa do direito à cidade e de moradia dos mais pobres.

Os casos analisados revelam que esta simbiose e a missão institucional da Defensoria Pública a conduzem para apresentar um discurso afinado com os 
princípios e conceitos do movimento pela reforma urbana, que batalhavam por cidades democráticas, que combatam a segregação espacial. A luta pelo abolicionismo revela que uma mudança de conceitos naturalizados, introjetados como habitus, ocorrem por uma transformação em diversas áreas da sociedade e que se refletem no campo jurídico.

O ativismo judicial entra neste contexto não apenas com o propósito de vencer ações judiciais, pois até mesmo nas derrotas há reflexos positivos - a exemplo das consequências políticas e até midiáticas que foram vistas nos casos e que trouxeram repercussões para além do Direito. Nos casos estudados foi visto como o Judiciário foi obrigado a realizar uma audiência de conciliação única para 11 processos (caso 03) ou como após a atuação Judicial, os entes estatais se veem obrigados a mudar a regulamentação legal de seus planos.

A maior imposição de novas práticas e argumentos podem alterar a ordem jurídica e social. Na verdade, a mudança de comportamento e de necessidades sociais, que trariam o entendimento da cidade de outra forma, alteraria as formulações jurídicas, ampliando a demanda pelo direito à cidade em uma vertente mais democrática. Isto não causaria uma revolução, pois o campo jurídico e a jurisprudência se adaptam aos novos problemas e às novas formas do Direito, gerando uma nova hierarquia que articula nos conceitos novos topoi, conformando a realidade.

Bourdieu ilustra que o aumento da força dos dominados no campo social e de seus representantes (partidos ou sindicatos) no campo jurídico gerou o desenvolvimento do direito do trabalho, do direito comercial e do que chama direito social. É certo que temos o debate sobre o direito à cidade como direito social no Brasil, e a articulação de um ramo do conhecimento chamado Direito Urbanístico, entretanto, sua utilização ainda não possui representatividade no campo jurídico, carecendo de força como topos, como foi visto no caso dos leilões do Governo Estadual em que refletiu-se que o direito à cidade possuía pouca habitualidade, potencialidade, intencionalidade e simbolicidade.

A articulação no campo jurídico tem o propósito, portanto, de gerar maiores repertórios de luta para os atores daquela causa, contribuindo para que o movimento ganhe mais pauta, interfira nas agendas públicas e ganhe espaço. Na medida em que o movimento se amplia, os profissionais do campo jurídico - a exemplo da Defensoria Pública - recebe maior representatividade no campo jurídico, alterando as relações 
hierárquicas e permitindo que o direito à cidade seja um topos significante para a concretização de uma ordem social no espaço urbano mais democrática.

A presente dissertação pretendeu traçar uma análise do desenvolvimento do direito à cidade na prática jurídica a partir da concepção de campo jurídico, que é formatado pela linguagem simbólica de seus profissionais, os quais concorrem pelo monopólio de dizer o direito. Assim, refuta-se o Direito como um sistema positivo dogmático, formado por conceitos, princípios e normas que propiciam soluções para todos os casos concretos, de forma imparcial.

Nesta perspectiva, o direito à cidade teria seu sentido disputado cotidianamente por todos os atores que concorrem no campo jurídico, que o criam e o transformam em sua prática. Desde um ato administrativo de um órgão estatal que pede informações sobre um conflito, um parecer emitido até uma decisão judicial há pressuposições sobre o direito à cidade que são colocadas em conflito com as noções de outras instituições, em busca de consolidação. Esta confrontação entre interpretações sobre o direito à cidade é conflituosa e contraditória, o que resulta na dominância de um conceito sobre outro, trazendo impactos na formação do espaço urbano.

Portanto, foi realizado um estudo sobre o desenvolvimento do direito à cidade, a partir da função criadora do Direito na pratica jurídica. O objetivo foi compreender com maior clareza quais os motivos de normas jurídicas como o direito à cidade ou 0 direito à moradia não alcançarem a efetividade esperada. Isto foi feito pela análise de casos concretos, perquirindo em quais pressupostos os discursos jurídicos de cada agente se fundamentam e observar os resultados destes confrontos na compreensão jurídica do direito à cidade e na vida real das pessoas envolvidas.

No primeiro caso, apresenta-se uma Prefeitura que tem um plano de intervenção em áreas de mananciais, que compreende como a maior violadora do meio ambiente a ocupação irregular de terras. Este ponto de vista não inclui as responsabilidades municipais de regular o solo urbano ou de executar o saneamento básico como parte do processo de segregação e degradação ambiental. Assim, a má formação do espaço urbano seria responsabilidade exclusiva das camadas pobres da população, que deveriam ser punidas por meio da remoção compulsória, sem mesmo ser-lhes ofertadas moradias. 
Esta concepção de cidade - que coloca o pobre como o gerador da desordem e da irregularidade - é versada no campo jurídico, a partir da formatação do Convênio com o Governo Estadual elaborando um plano de intervenção, pela criação da Ordem Interna ํㅡ 01/2007, que detalha a atuação, até culminar na própria defesa processual formalizada pela Procuradoria Municipal. Em todos os atos vê-se um topos do Estado como legitimado a combater pessoas que constroem a cidade de forma ilícita, sem necessidade de qualquer controle pelo Poder Judiciário.

No segundo caso, o Governo Estadual possui um plano de venda de imóveis, alienando-os como mero passivo patrimonial a ser capitalizado pela venda em leilões, com o objetivo de financiar um programa de parcerias público-privadas. É notável que a cidade é tida como mero palco para negócios, um instrumento para se conseguir recursos para obras de infraestrutura que gerem desenvolvimento econômico. A melhoria das condições sociais é vista como decorrência natural do crescimento econômico, pois qualquer responsabilidade governamental na ingerência direta quanto ao desenvolvimento urbano ou social é desprezada. As intervenções da Procuradoria do Estado, assim como os procedimentos administrativos das licitações ou os comunicados às famílias residentes nos imóveis trazem um discurso jurídico que evidencia esta acepção de cidade.

No terceiro caso, o Ministério Público apresenta um topos sobre o meio ambiente que reflete uma ideologia da ordem, a qual percebe o ambiente natural como algo intocável, entende as moradias em área de risco como geradoras dos danos e exige intervenções radicais do Poder Executivo Municipal para reestabelecer o status anterior. O Ministério Público trabalha tanto por meio de peças judiciais e como por procedimentos administrativos (Procedimentos de Investigação Preliminar), em que se apresenta sua visão da realidade convertida em discurso jurídico.

A cidade é trabalhada pelo Ministério Público como um espaço ideal em que todo espaço urbano é formado por parcelamentos do solo regularizados, com o meio ambiente natural completamente preservado. Não há uma ponderação com a realidade social em que a maior parte dos loteamentos é irregular - onde as famílias que ocupam áreas de risco não têm para onde ir caso removidas - ou com a ótica de que interação humana com a natureza faz com que os conceitos de preservação sejam flexibilizados.

No quarto caso têm-se um Governo Estadual que possui uma legislação criando um programa de locação social que, porém, jamais foi executado. Após 16 
anos de omissão do Poder Executivo Estadual em efetivar a referida política pública, houve a propositura de um Mandado de Injunção por uma entidade social que articula o direito à moradia para idosos, representados pela Defensoria Pública. Em resposta, os discursos apresentados pela Procuradoria Estadual, Ministério Público e Poder Judiciário são idênticos, impedindo qualquer interferência na autonomia do Poder Executivo.

Nos três primeiros casos relatados a Defensoria Pública se apresenta articulando uma defesa pela permanência das famílias em suas residências. No caso 01 são utilizados topoi como regularização fundiária, nulidade de atos administrativos e moradia digna. Estes "sensos comuns" estabelecem um discurso que traz a responsabilidade municipal de regulação do solo urbano em primeiro plano, exigindo que seu planejamento ambiental inclua a perspectiva de regularização das habitações das pessoas ou lhes destine uma moradia digna. Nesta lógica, não há outra conclusão senão da nulidade das Ordens Internas, o que impede o Município de discutir nesta linha, lançando-o pela busca de um topos como autonomia do Poder Executivo, o que tornaria seus atos inquestionáveis na via judicial.

O topos da autonomia do Poder Executivo é recorrente na jurisprudência, pois permite que não se abra o debate em busca do consenso, tal como Theodor Viehweg defende. Nota-se que mais forte que o confronto de topoi visando a uma composição é o poder simbólico do agente no campo jurídico, de modo que se impede o debate pela imposição de uma das visões. Não se encontra na maior parte das sentenças uma articulação entre todos os pressupostos colocados pelos litigantes, mas o desenvolvimento de uma única linha de raciocínio, que irá resultar na não discutibilidade dos atos da administração pública.

A conclusão que se tira é de que o raciocínio do Theodor Viehweg pode não ser aplicável em totalidade na realidade brasileira, em que não se tem uma cultura democrática na qual o Estado justificaria todos os seus atos. A prática de realização de planejamentos e tomadas de decisões sem a devida transparência, fazem parte de uma tradição autoritária, em que os Estado se legitima suas práticas apenas pela representação do bem comum. O fator preponderante, portanto, não se torna a busca dos topoi mais adequados para o caso concreto, conduzindo a um debate sobre as justificativas das medidas tomadas, mas a imposição a partir da quantidade de capital simbólico que a instituição ou profissional detém. 
No caso 02 há um discurso de direito administrativo, novamente, pela nulidade de atos, assim como fundamentos sobre o tempo de posse que geraria direito de Concessão de Uso Especial para Fins de Moradia. O topos central é o direito de defesa, que foi lesado pelas licitações, impedindo que as famílias pudessem demonstrar a legitimidade de sua posse. Neste caso, como a posse das famílias representa a conquista de um direito subjetivo, a Procuradoria do Estado lança um conflito entre um interesse geral de toda a coletividade - desenvolvimento econômico e social - contra o interesse individual das famílias ameaçadas da perda de sua moradia.

Assim como no caso anterior, o Governo Estadual lança um topos que permite a solução da aporia não pelo debate de direitos, mas pela imposição trazida pelo capital simbólico de uma entidade que se coloca como representante dos interesses de toda a coletividade. Assim, o debate se simplifica, pois deixa de se debater o direito à moradia ou a nulidade de atos administrativos, para se discutir qual o maior e mais legítimo interesse: dos cidadãos paulistas ou dos moradores das residências ameaçadas de remoção.

O caso 03 é o único que apresenta uma discussão a exemplo do que Viehweg coloca, ou seja, todos os atores apresentando seus topoi, porém buscando uma composição que é colocada a termo pelo julgador. Isso ocorre, primeiro por ser inevitável para quaisquer das partes deixar de abordar o tema do meio ambiente. Por um lado, a Defensoria Pública o faz utilizando topoi que conduzam para um equilíbrio da relação entre população e natureza, com termos como dignidade humana, direito à moradia e risco ambiental, que é trabalhado com conceitos técnicos em defesa civil. O Ministério Público utiliza do meio ambiente em seu estado primitivo, que deve ser recomposto a todo custo, para o bem das futuras gerações.

O resultado final em que uma audiência de conciliação traz um acordo para 11 Ações Civis Públicas é possível pois a busca dos topoi giram apenas em torno de dois elementos - meio ambiente e moradia - em que todos os agentes se propõem a discutir. Além disso, há um grande risco por trás da imposição de uma sentença pelo Juízo, que seria colocar em descrédito o Poder Executivo municipal, também dotado de grande capital simbólico. Este talvez seja o grande fator que conduz ao resultado negociado entre todas as partes.

No caso 04 da locação social, a Defensoria Pública atua na exigência de uma política pública de moradia - não no papel reativo de impedir remoções - o que traduz 
um conceito de direito à cidade mais amplo: como acesso a bens e serviços na cidade. Esta construção, no caso 04 é prontamente rechaçada pelo Governo Estadual, Ministério Público Estadual e pelo órgão máximo do Poder Judiciário, o que leva a Defensoria a desistir de qualquer estratégia de conduzir o caso para instâncias superiores.

A recusa acima demonstra que que o conceito de cidade como direito a bens e serviços, ou seja, como espaço de garantia da cidadania não é algo aceito por nenhuma das instituições, pois entendem que é a discricionariedade do Poder Público que deve definir como este ideal se implementa. Este tipo de noção de direito à cidade é rejeitado pois coloca em risco os paradigmas de um sistema político representativo, tendo em vista que o mero fato de uma pessoa ser parte de uma cidade lhe permitiria reivindicar judicialmente a implementação de uma política pública. Nos outros casos, o direito à cidade aparece como direito à permanência no local e resistência contra escolhas do Estado, sendo mais fácil de ser trabalhado e aceito, pois não questiona pressupostos básicos de democracia representativa.

Em relação ao Poder Judiciário, foi possível verificar que suas decisões podem ser completamente diferentes e até mesmo contraditórias dentro um mesmo tipo de conflito. No caso 01 o magistrado assume os topoi trazidos pela Procuradoria Municipal e expressa uma concepção de cidade a partir de uma ordem urbanística legalizada pelo controle do uso do solo pela municipalidade, tratando moradores de áreas irregulares como contrários à lei e não merecedores de qualquer atenção das políticas públicas. Em outra ação civil pública (ACP) similar o Poder Judiciário se afirma como viabilizador da promessa constitucional de assegurar o direito de moradia, o que o impele a interferir no Poder Executivo para garantir tal direito, independentemente de haver norma regulamentadora.

A diferença entre os dois casos não estava na existência de dois julgadores diferentes ou em sua técnica interpretativa, mas no fato de que no primeiro caso as famílias continuavam no local, enquanto no segundo caso, já haviam sido retiradas por uma ação de reintegração de posse. A sentença de procedência da ACP não teria qualquer repercussão sobre a legitimidade da Prefeitura frente ao plano de recuperação de mananciais e nem mesmo garantiria o recebimento imediato de moradias pelas famílias. Assim, a sentença manteria a ordem pretendida pela Municipalidade, ao tempo que conferiria a sensação de que o outro disputante - 
Defensoria Pública - também obteria êxito em suas pretensões, prestigiando o poder simbólico de ambas as instituições.

No caso 02, pela interposição da suspensão de segurança pela Procuradoria do Estado fica nítido como o Judiciário é permeado por discussões de ordem meramente políticas, em que se torna mais importante garantir a ordem do que afirmar a suposta lógica do sistema normativo. Por outro lado, no caso 03 o Judiciário gera uma solução não prevista expressamente no ordenamento jurídico, ao agregar em uma mesma audiência 11 ações civis públicas, fazendo com que em um único ato judicial se aplique uma mesma pactuação para todos os casos, evitando uma decisão judicial.

Nos dois exemplos mostra-se, por motivos diferentes, como a legislação é afastada para que se encontre a resolução que se entende mais adequada. Esta diversidade de posturas do Poder Judiciário não ocorre apenas por haver uma pluralidade de Juízos, mas por uma necessidade de absorção de insegurança e de conservação do poder. Isso ocorre, pois, a imposição da ordem legal muitas vezes implica em generalizar o conflito, o que acabaria por explicitar para toda a sociedade a crise de legitimidade da ordem legal e do regime que sustenta (FALCÃO, 2008, p. 117). Os casos, portanto, reforçam a tese de que os juristas precisam resolver os casos pelo pensamento problemático, pois o pensamento sistemático não traz respostas adequadas quando surgem aporias.

No caso 03, o acolhimento das ACP's propostas pelo Ministério Público representaria a imposição de sentenças inexequíveis pelo Município de Poá-SP, o que colocaria em dúvida a capacidade do Poder Executivo em realizar sua missão, assim como a do Poder Judiciário em impor suas ordens. Por outro lado, o não acolhimento das ACP's do Parquet poderia representar um descaso com as áreas de risco e colocar em questão a autoridade do Ministério Público como fiscal da lei.

Em que pese a aparente aleatoriedade das decisões judiciais, o padrão de comportamento do Poder Judiciário em todos os casos é o mesmo: a preocupação com a preservação da ordem e com conservação ou expansão de seu poder pela manutenção da autoridade das suas decisões. O Poder Judiciário, portanto, não tem como sua maior preocupação a garantia de direitos, mas a absorção de insegurança, atuando como agente estabilizador da ordem.

Isso é feito pela avaliação, em cada caso concreto, de qual tipo de decisão pode desequilibrar ao mínimo as relações de poder estabelecidas, o que trará maior 
probabilidade de que a decisão judicial seja cumprida e que a autoridade do Judiciário não seja contestada ou confrontada por outro agente com grande hierarquia de poder.

Conclui-se, portanto, que o maior entrave para a aceitação do direito à cidade por um discurso de justiça social não é a falta de conhecimento do direito à cidade pelos magistrados ou um perfil reacionário do Judiciário. Em diversas decisões temse o Poder Judiciário articulando noções de cidade ou do direito à moradia aceitandoo como uma obrigação estatal, independente de regulamentação.

O problema central reside nos agentes representantes da ordem. A disputa judicial não se trata de uma rivalidade retórica, em que se busca o convencimento do magistrado, mas de uma concorrência pelo poder de monopólio do Direito. Assim, os agentes com maior poder político tendem a impor sua visão, sendo portadores de maior capital simbólico, definindo a o formato da ordem jurídica.

Nos casos 01 e 02 o proferimento de decisões que anulassem a Ordem Interna no 01/2007 ou as licitações para venda de imóveis inviabilizaria toda uma política pública desenvolvida, com grande interesse econômico de fundo, o que colocaria o Poder Judiciário em confronto institucional direto. Portanto, no momento em que no caso 01 uma ação de reintegração de posse remove os moradores da área de mananciais, se torna possível apresentar uma decisão afirmando o direito de moradia pela inclusão das famílias em lista de recebimento de imóveis, pois a política de remoção de pessoas na área de mananciais estava garantida. Do mesmo modo, no caso 02 se torna possível a anulação das licitações no momento em que a suspensão de segurança permite as vendas para capitalização das parcerias público privadas.

Sobre o conteúdo do direito à cidade trabalhado pela Defensoria Pública, observa-se que nos casos em que há risco de remoção de famílias (casos 01, 02 e 03), o direito à cidade para a Defensoria Pública se traduz em direito à localização da população pobre. $O$ direito à cidade como direito de localização dos pobres exige que as políticas públicas sejam pensadas incluindo sua perspectiva. Assim, se os agentes públicos não tiverem como pressuposto de seus planejamentos a participação democrática, o direito de localização será superior à discricionariedade administrativa, ao direito de propriedade, ao meio ambiente e ao princípio da separação dos Poderes.

Esta concepção de direito à cidade não é a única trabalhada pela Defensoria Pública, pois no caso 04 , tem-se um exemplo de sua lógica como acesso a bens e serviços. Porém, a busca constante de moradores e movimentos sociais pelo serviço do Núcleo de Habitação e Urbanismo, quando em risco de remoção acabam 
conduzindo a instituição a traduzir, de forma majoritária, o direito à cidade como localização e resistência.

Em relação aos demais atores jurídicos, ainda que estes não utilizem de conceitos do direito urbanístico, eles possuem compreensões sobre à cidade que são trabalhadas juridicamente, não apenas na via judicial, mas em cada ato emitido em forma jurídica. Não se entende, portanto, que os profissionais do direito ignoram o direito à cidade, mas apenas não necessitam do conjunto de princípios e regras que desenvolvem o chamado direito urbanístico, pois estes não conduzem às conclusões que suas necessidades exigem.

O direito à cidade ou à moradia não possuem conteúdo prévio, sendo interpretados em cada ato dos agentes que o articulam. Nos casos concretos vemos: a) a cidade como fruto da manutenção da ordem legal, por meio do parcelamento e controle do uso do solo; b) cidade como palco de investimentos; c) cidade como processo de urbanização que agride o meio ambiente natural; d) cidade como direito de uso do espaço, gerando o direito à permanência. $O$ embate que ocorre judicialmente destes conceitos consolida uma cultura jurídica sobre seu significado. Aos poucos forma-se o habitus em relação ao que o direito ou o acesso à cidade representa juridicamente.

Considerando isto, a Defensoria Pública cumpre um papel importante de traduzir uma visão sobre à cidade afinada com os anseios da população excluída de baixa renda - articulando no campo jurídico este discurso jurídico. Esta instituição detém legitimidade como ente estatal, estrutura e orçamento que permitem adquirir posição hierárquica no campo jurídico suficiente para combater os entendimentos naturalizados de propriedade, supremacia do Estado ou discricionariedade da administração pública, ao menos para realizar o papel de resistência.

As lições de Theodor Viehweg que explicam que a prática jurídica se orienta a partir dos problemas, buscando-se sensos comuns que orientam o debate, associado ao pensamento de Pierre Bourdieu em que as instituições e profissionais jurídicos impõe sua visão sobre o Direito, de acordo com o capital simbólico que possuem, foram elementos chave para elucidar as relações de poder em cada caso concreto. Permitiu-se, em decorrência, que se demonstrasse uma justificação plausível de como se desenvolve a luta jurídica pelo direito à cidade e quais os motivos de sua ineficiência sob a lógica de justiça social. 
Exemplos históricos como a luta abolicionista - que combatia a escravidão que era tida como um conceito natural - demonstram que o papel central da Defensoria Pública - e seu Núcleo de Habitação e Urbanismo - seria de conferir repertórios de mobilização para atores sociais de luta por cidades democráticas, tendo em vista que a disputa real está na política e não no Direito.

Se as relações hierárquicas de poder forem diferentes, o Poder Judiciário agirá como elemento estabilizador, configurando uma nova ordem. Portanto, o vislumbre de uma mudança do Poder Judiciário em relação à recepção de uma organização urbana que combata a desigualdade social, com um direito à cidade que represente conquistas aos mais pobres apenas pode surgir com um desequilíbrio nas relações de poder existentes. Em outras palavras, a solução não está no Direito, mas na esfera política e social. 


\section{BIBLIOGRAFIA}

I diagnóstico da Defensoria Pública no Brasil. -- Brasília : Ministério da Justiça, Secretaria de Reforma do Judiciário, 2004.

III diagnóstico da Defensoria Pública no Brasil. -- Brasília : Ministério da Justiça, Secretaria de Reforma do Judiciário, 2009.

ALONSO, Ângela. Flores, votos e balas: o movimento abolicionista brasileiro (186888). 1‥ed. São Paulo: Companhia das Letras, 2015.

ALVES, Adjair. Teorias de "poder" na relação entre indivíduos e/ou instituições no processo de organização social: um diálogo entre Foucault, Balandier e Bourdieu. Diálogos - Revista Diálogos, n. 3, p. 134-156. 2o semestre.2010. Disponível em: http://www.revistadialogos.com.br/dialogos_3/dial_3_adjairalves.pdf . Acesso em: 26 fev. 2018.

BARROSO, Luís Roberto. Constituição, democracia e supremacia judicial: direito e política no Brasil contemporâneo. Revista de Direito do Estado. Rio de Janeiro: Ed. Renovar, v.16, p. 3-42, 2010. Disponível em: <http://www.epublicacoes.uerj.br/index.php/rfduerj/article/view/1794> Acesso em: 27 nov. 2016

BASSANI, Jorge; NOBRE, Eduardo Alberto Cusce. Intervenções urbanas em áreas em transformação de cidades da América Latina: o que aprender com elas? In: BASSANI, Jorge; NOBRE, Eduardo Alberto Cusce (org.) Intervenções urbanas em áreas em transformação de cidades da América Latina - São Paulo: FAUUSP, 2015.

BERCOVICl. Gilberto. Estado intervencionista e Constituição Social no Brasil: o silêncio ensurdecedor de um diálogo entre ausentes. In: SOUZA NETO, Cláudio Pereira de; SARMENTO, Daniel; BINENBOJM, Gustavo. (Org.) Vinte anos da Constituição Federal de 1988. Rio de Janeiro: Lumen Juris, 2009.

BITTAR, Carlos Eduardo Bianca. Curso de Filosofia do Direito. $12^{\underline{a}}$ ed. Ver. Atual e apl. - São Paulo: Atlas, 2016

BORJA, J.; CASTELLS, M. Local \& Global: management of cities in the information age. Londres: Earthscan Publications Ltd., 1997. Cap. 5 - Cities as political agents. p. 90-117. 
BOURDIEU, Pierre. O Poder Simbólico. 16 ed. Rio de Janeiro: Bertrand Brasil, 2012.

BRASIL. Constituição, 1988. Constituição da República Federativa do Brasil. Disponível em

http://www.planalto.gov.br/ccivil 03/constituicao/constituicaocompilado.htm Acesso em 28 nov. 2016.

BRASIL. Lei no 8.437, de 30 de junho de 1992. Dispõe sobre a concessão de medidas cautelares contra atos do Poder Público e dá outras providências. Disponível em <https://www.planalto.gov.br/ccivil 03/leis/L8437.htm> Acesso em 28 nov. 2016.

BRASIL. Lei no 10.257, de 10 de julho de 2001. Regulamenta os arts. 182 e 183 da Constituição Federal, estabelece diretrizes gerais da política urbana e dá outras providências.

Disponível

em

<https://www.planalto.gov.br/Ccivil 03/leis/LEIS 2001/L10257.htm> Acesso em 28 nov. 2016.

BRASIL. Medida Provisória no 2.220 de 4 de setembro de 2001. Dispõe sobre a concessão de uso especial de que trata o $\S 1$ 으 do art. 183 da Constituição, cria o Conselho Nacional de Desenvolvimento Urbano - CNDU e dá outras providências. Disponível em < http://www.planalto.gov.br/ccivil 03/mpv/2220.htm > Acesso em 28 nov. 2016.

BURGUER, Adriana Fagundes. BALBINOT, Christine. A nova dimensão da Defensoria Pública a partir das alterações introduzidas pela Lei Complementar nำ132 na Lei Complementar no 80/94. In SOUSA, José Augusto Garcia de. Uma nova defensoria pública pede passagem: reflexões sobre a Lei Complementar 132/09. 1ed. Rio de Janeiro. Lumen Juris, 2011.

CAPPELLETTI, Mauro. BRYANT, Garth. Acesso à justiça. Tradução Ellen Gracie Northfleet. Porto Alegre: Sergio Antonio Fabris Editor, 1988

CARDOSO, Evorah Lusci Costa. Cortes supremas e sociedade civil na América Latina: estudo comparado Brasil, Argentina e Colômbia. Disponível em: http://www.teses.usp.br/teses/disponiveis/2/2139/tde-16052013-162225/pt-br.php > Acesso em 22 dez. 2016. 
CARDOSO, Luciana Zaffalon Leme. Uma fenda na justiça: a Defensoria Pública e a construção de inovações democráticas. São Paulo: Hucitec, 2010.

CUNHA, Elza Antonia Pereira. O discurso jurídico e a ideologia do interesse geral. Florianópolis, 1984.

CUNHA, Leonardo José Carneiro da. A Fazenda Pública em juízo. São Paulo. Dialética, 2010.

FALCÃO, Joaquim de Arruda (org.). Invasões Urbanas: conflito de direito de propriedade. 2.ed. Rio de Janeiro: Editora FGV, 2008.

FERNANDES, Edesio. Estatuto da Cidade, mais de 10 anos depois: razão de descrença, ou razão de otimismo? Disponível em: < https://www.ufmg.br/revistaufmg/downloads/20/10estatuto da cidade edesio fernandes.pdf> Acesso em: 05 jan. 2017.

FERRAZ JR., Tercio Sampaio. A Ciência do Direito. São Paulo, Atlas. 2002 Tercio Sampaio. Introdução ao estudo do direito: técnica, decisão e dominação. 4⿳亠丷a ed. São Paulo, Atlas. 2003

FERREIRA, Paulo Emílio. Urbanização de favelas versus desfavelamento: Notas sobre uma operação paulistana. In: D'OTTAVIANO, C.; ANTONUCCI, D.; SHIMBO, L. (orgs.). Congresso Internacional da Habitação no Espaço Lusófono: Anais do 3 CIHEL - Habitação: urbanismo, cultura e ecologia dos lugares. São Paulo: Faculdade de Arquitetura e Urbanismo da Universidade de São Paulo, p. 252-266, 2015

FIX, Mariana. Parceiros da exclusão: duas histórias de construção de uma "nova cidade" em São Paulo: Faria Lima e Água Espraiada. São Paulo: Boitempo, 2001.

FUCKS, Mário. Arenas de Ação e Debate Públicos: Conflitos Ambientais e a Emergência do Meio Ambiente enquanto Problemas Social no Rio de Janeiro. Disponível em: < http://www.scielo.br/scielo.php?script=sci arttext\&pid=S0011 -

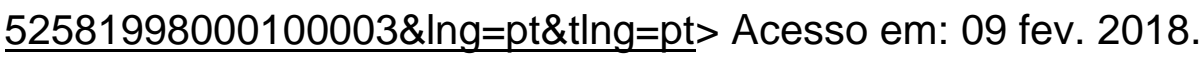

GÜELL, J. M. Planificación Estratégica de Ciudades. Barcelona: Gustavo Gilli, 1997. Cap. 3 - Planificación Estratégica de Ciudades. 
JUNQUEIRA, Eliane Botelho. Acesso à Justiça: um olhar retrospectivo.. Revista Estudos Históricos, Rio de Janeiro, v. 9, n. 18, p. 389-402, dez. 1996. ISSN 21781494.

em:

$<$ http://bibliotecadigital.fgv.br/ojs/index.php/reh/article/view/2025/1164>. Acesso em: 05 Jul. 2017.

MARTINS, Maria Lucia Refinetti. Moradia e Manciais: tensão e diálogo na metrópole. São Paulo: FAUUSP/FAPESP, 2006.

MOURA, Alexandrina Sobreira de. Terra do mangue: invasões urbanas no Recife. Recife: FUNDAJ, Editora Massangana, 1990.

MESSITTE, Peter. Assistência judiciária no Brasil: uma pequena história. Revista Forense, São Paulo, jun. 1968.

NOBRE, E. A. C. Quem ganha e quem perde com os Grandes Projetos Urbanos? Avaliação da Operação Urbana Consorciada em São Paulo. Cadernos IPPUR, v. 23, p. 203-219, 2009.

OLIVEIRA, Simone dos Santos. Defensoria pública brasileira: sua história. Revista de Direito Público 2007; 2(2):59-74.

ORDACGY, André da Silva. As ações coletivas pela Defensoria Pública na novel reforma da Lei Complementar 80/94. In SOUSA, José Augusto Garcia de. Uma nova defensoria pública pede passagem: reflexões sobre a Lei Complementar 132/09. 1ed. Rio de Janeiro. Lumen Juris, 2011.

PINHO, F. O. . Tópica e Argumentação Jurídica: considerações sobre a dignidade humana como tópos. In: I CONGRESO DE FILOSOFÍA DEL DERECHO PARA EL MUNDO LATINO, 2016, Alicante. I CONGRESO DE FILOSOFÍA DEL DERECHO PARA EL MUNDO LATINO, 2016

ROESLER, Cláudia Rosane. Theodor Viehweg e a Ciência do Direito: Tópica, Discurso e Racionalidade. Florianópolis: Momento Atual, 2004.

ROLNIK, Raquel. 10 Anos Do Estatuto da Cidade: das Lutas Pela Reforma Urbana às Cidade da Copa do Mundo. Disponível em: < https://raquelrolnik.files.wordpress.com/2013/07/10-anos-do-estatuto-da-cidade.pdf> Acesso em: 05 jan. 2017. 
SADEK, Maria Tereza Aina. Defensoria Pública: a conquista da cidadania. In Temas Aprofundados Defensoria Pública. Vol. 1. Organizador Aluísio lunes Monti Ruggeri Ré. 2 ${ }^{\mathrm{a}}$ Tiragem. Salvador: JusPodivm, 2014.

. (org.). O Sistema de Justiça. Rio de Janeiro, Centro Edelstein de Pesquisas Sociais, 2010.

SANTOS, Boaventura de Sousa. Pela mão de Alice: o social e o político na pósmodernidade. 11. Ed. São Paulo: Cortez, 2006.

SANTOS, Márcio Achtschin. Uma leitura do campo jurídico em Bourdieu. Águia: Revista Científica da FENORD, v.01, p.90-105, 2011.

SÃO PAULO. I Jornada em Defesa da Moradia Digna / Defensoria Pública do Estado de São Paulo. - 1. ed. - São Paulo: Defensoria Pública do Estado de São Paulo, 2008.

SAULE JR, Nelson (org.). Direito Urbanístico - vias jurídicas das políticas urbanas. Porto Alegre, Sergio Antonio Fabris Editor, 2007.

SHIRAISHI NETO, Joaquim. O campo jurídico em Pierre Bourdieu: a produção de uma verdade a partir da noção de propriedade privada nos manuais de Direito. Seqüência: Estudos Jurídicos e Políticos, Florianópolis, p. 83-100, set. 2010. ISSN 2177-7055. Disponível em: <https://periodicos.ufsc.br/index.php/sequencia/article/view/21777055.2008v29n56p83/13672>. Acesso em: 27 fev. 2018. doi:https://doi.org/10.5007/2177-7055.2008v29n56p83.

STRECK, Lênio Luiz. Hermenêutica jurídica $\mathbf{e}(\mathbf{m})$ crise: uma exploração hermenêutica da construção do Direito. 11ed. rev.atual.e ampl - Porto Alegre: Livraria do Advogado Editora, 2014.

WARAT, Luis Alberto. Introdução Geral ao Direito - Vol. 1. Porto Alegre: Sérgio Fabris Editor, 1995.

. Introdução Geral ao Direito - Vol. 2. Porto Alegre: Sérgio Fabris Editor, 1995.

Introdução Geral ao Direito - Vol. 3. Porto Alegre: Sérgio Fabris Editor, 1997.

VIEHWEG, T. Tópica e Jurisprudência, trad. T. S. Ferraz Jr., Brasília, Departamento de Imprensa Nacional, 1979. 
VITTO, Renato Campos Pinto de. O uso dos meios alternativos de resolução de conflitos e a atuação interprofissional da Defensoria Pública: o novo enfoque do acesso à justiça na LC/132/2009. In SOUSA, José Augusto Garcia de. Uma nova defensoria pública pede passagem: reflexões sobre a Lei Complementar 132/09. 1ed. Rio de Janeiro. Lumen Juris, 2011. 